\title{
Recent Advances in Microwave-Assisted Copper-Catalyzed Cross-Coupling Reactions
}

\author{
Younis Baqi
}

check for

updates

Citation: Baqi, Y. Recent Advances in Microwave-Assisted

Copper-Catalyzed Cross-Coupling

Reactions. Catalysts 2021, 11, 46 .

https://doi.org/10.3390/catal11010046

Received: 11 December 2020

Accepted: 28 December 2020

Published: 31 December 2020

Publisher's Note: MDPI stays neutral with regard to jurisdictional clai$\mathrm{ms}$ in published maps and institutional affiliations.

Copyright: (C) 2020 by the author. Licensee MDPI, Basel, Switzerland. This article is an open access article distributed under the terms and conditions of the Creative Commons Attribution (CC BY) license (https:// creativecommons.org/licenses/by/ $4.0 /)$.
Department of Chemistry, College of Science, Sultan Qaboos University, P.O. Box 36, Muscat 123, Oman; baqi@squ.edu.om; Tel.: +968-2414-1473

\begin{abstract}
Cross-coupling reactions furnishing carbon-carbon $(\mathrm{C}-\mathrm{C})$ and carbon-heteroatom $(\mathrm{C}-\mathrm{X})$ bond is one of the most challenging tasks in organic syntheses. The early developed reaction protocols by Ullmann, Ullman-Goldberg, Cadiot-Chodkiewicz, Castro-Stephens, and Corey-House, utilizing elemental copper or its salts as catalyst have, for decades, attracted and inspired scientists. However, these reactions were suffering from the range of functional groups tolerated as well as severely restricted by the harsh reaction conditions often required high temperatures $\left(150-200{ }^{\circ} \mathrm{C}\right)$ for extended reaction time. Enormous efforts have been paid to develop and achieve more sustainable reaction conditions by applying the microwave irradiation. The use of controlled microwave heating dramatically reduces the time required and therefore resulting in increase in the yield as well as the efficiency of the reaction. This review is mainly focuses on the recent advances and applications of copper catalyzed cross-coupling generation of carbon-carbon and carbon-heteroatom bond under microwave technology.
\end{abstract}

Keywords: cross-coupling reaction; Cu catalyst; microwave irradiation; methodology; synthesis

\section{Introduction}

Carbon-carbon $(\mathrm{C}-\mathrm{C})$ and carbon-heteroatom $(\mathrm{C}-\mathrm{X})$ bond formations through crosscoupling reactions represents as one of the most useful strategy in the synthetic organic chemistry, hence many procedures and methodologies have been developed and published in the literature. Elemental copper $(\mathrm{Cu})$ is the first transition metal element used to catalyze the formation of $\mathrm{C}-\mathrm{C}$ and $\mathrm{C}-\mathrm{X}$ bond. The first report of copper in catalyzing $\mathrm{C}-\mathrm{C}$ bond formation was proposed by Fritz Ullman in 1901. Followed by the modification of the classical Ullmann reaction to include $C-X$ bond, was reported by Ullman and Goldberg in the years from 1903 to 1906 . The progress was followed by Cadiot-Chodkiewicz coupling reaction in 1957, Castro-Stephens coupling reaction in 1963, and Corey-House synthesis in 1967. In the 1970s, the cross coupling reaction entered a new era by introducing palladium $(\mathrm{Pd})$ as one of the most powerful noble metal in the cross-coupling reactions. Many important chemical transformations to generate new organic molecules have been developed and these reactions being named after the person who discovered it, including Kumada and Heck (1972), Sonogashira (1975), Negishi (1977), Stille (1978), Suzuki (1979), Hiyama (1988), and Liebeskind-Srogl (2000). Despite the great advances in utilizing palladium as catalyst, copper is still very much used as one of the important catalyst, being non-noble metal, which is cheap and available in the most organic synthetic laboratories globally. However, in comparison with palladium, copper catalyzed reactions are often suffering from the tolerance to cover variety of functional groups as well as the stability of starting materials and products due to the essentially required harsh reaction conditions such as high temperatures-typically $150-200{ }^{\circ} \mathrm{C}$ - and for the extended reaction time from several hours to few days [1-4].

Upon the discovery of microwave technology, as an alternative heating source for organic reactions, it has gained much attention due to its high efficiency, reproducibility, 
and shortening the reaction time. This fulfills the requirements of green chemistry reactions as well as reducing solvents consumption, reaction temperature, and the extended reaction time to less than an hour, while many reactions are being done in few to several minutes. This is usually accompanied with significant reduction of energy consumption, raising the efficiency and yield of the desired product, through lowering the level of side reactions $[5,6]$. Therefore, the discovery of the microwave heating in organic chemistry has revived the application of copper in cross-coupling reaction to access novel organic compounds via the formation of new $\mathrm{C}-\mathrm{C}$ and $\mathrm{C}-\mathrm{X}$ bonds.

This review article is aiming to highlight the recent advances and perspectives of copper-catalyzed cross-coupling $\mathrm{C}-\mathrm{C}$ and $\mathrm{C}-\mathrm{X}$ bond formation under controlled microwave heating. Although it covers the most recent methodologies published in the last decade, but priority will be given to the protocols bearing transformation of wide-range of substrates, emphasizing on their utility and restrictions to simplify the further development of this very attractive area of research.

\section{Copper-Catalyzed Cross-Coupling Reactions under Microwave Irradiation}

\subsection{Ullmann-Type Cross-Coupling Reactions}

Ullmann coupling reaction is the first reported cross-coupling reaction that uses a transition metal as catalyst. It has been developed by Fritz Ullmann for the synthesis of symmetrical biaryl compounds via the generation of new $\mathrm{Ar}-\mathrm{Ar}(\mathrm{C}-\mathrm{C})$ bond starting from an aryl halide and mediated by elemental copper $(\mathrm{Cu} 0)$ [7]. In the next few years, Ullmann reaction has been modified to involve the coupling of aryl halides and various nucleophiles for the generation of other carbon-heteroatom $(C-X)$ bonds, such as $C-N$, $\mathrm{C}-\mathrm{O}$, and $\mathrm{C}-\mathrm{S}[8-11]$.

For the last 20 years, Müller and coworkers are been interested in the synthesis of diverse range of anthraquinone derivatives for their pharmacological activity as antagonists for purinergic P2 receptors as well as ectonucleotidases inhibitors [12-20]. However, the anthraquinone chemistry undergo Ullmann coupling reaction under classical conventional heating were very much limited to the activated amines and anilines with significant low yield and extended reaction times for up to $48 \mathrm{~h}$ under harsh reaction conditions. Baqi, Y. et al. were the first to systematically investigate the effect of microwave irradiation on the Cu-catalyzed Ullmann coupling reaction using three different oxidation states of copper, namely elemental copper $(0)$ powder $(\mathrm{Cu})$, copper $(\mathrm{I})$ chloride $(\mathrm{CuCl})$, and copper (II) sulfate $\left(\mathrm{CuSO}_{4}\right)$. The three oxidation states of copper $(0, \mathrm{I}$, and II) were investigate, in a comparison manner, under conventional heating and microwave technology [21,22]. The most significant achievement was when they employed a catalytic amount (5 mol\%) of elemental copper in phosphate buffer $\left(\mathrm{NaH}_{2} \mathrm{PO}_{4}\right.$ and $\left.\mathrm{Na}_{2} \mathrm{HPO}_{4}\right)$ at $\mathrm{pH} 6-7$, as solvent under microwave irradiation, Scheme 1. The developed protocol has been successfully employed for the synthesis of a small library (about 200 compounds) of amino- and anilinoanthraquinones, where most of these compounds were previously inaccessible under classical Ullmann reaction using conventional heating.

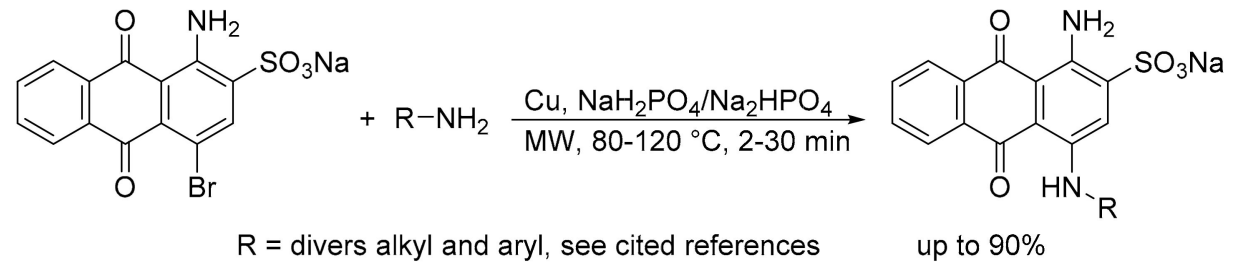

Scheme 1. Elemental copper $(\mathrm{Cu})$ catalyzed microwave-assisted synthesis of the anthraquinones.

The generality of this protocol was further examined on other aryl halide scaffold and found to be useful. For example, Georg and his coworkers have employed the above mentioned protocol for the synthesis of 8-anilinonaphthalene-1-sulfonic acid derivatives. Similarly they have found that the use of elemental copper in phosphate buffer to be 
superior over other used copper based catalysts [23]. However, the reaction has relatively taken longer time, about 60-90 min, compared to the same reactions being performed under microwave heating. The product was obtained in low to good yields, Scheme 2 . This low yield is probably due to the halide used, a chloride ion being less effective leaving group compared with bromide ion, while the presence of a carbonyl function in the anthraquinone core might have a direct impact on the stabilization of the intermediate generated in the catalytic cycle through possible coordination bond between the free lone pair on the oxygen atom of the carbonyl group and copper surface thus facilitate the reaction towards the desired product in shorter reaction time, therefore, it may minimize any competitive side reactions, which is the main cause of losing the yields.

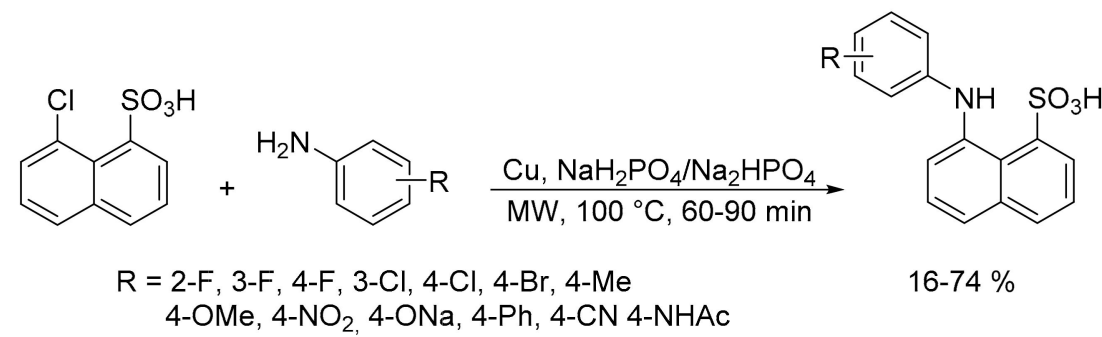

Scheme 2. Microwave-assisted synthesis of 8-anilinonaphthalene-1-sulfonic acid.

Park, A.R. and Yum, E.K. have developed microwave assisted synthesis of isoquinolines using copper $(\mathrm{I})$ oxide $\left(\mathrm{Cu}_{2} \mathrm{O}\right)$ [24]. They have systematically optimized the reaction using different kind and equivalent of the catalyst, base, solvent, and reaction time. They have concluded that the optimal conditions for $N$-arylation of isoquinolines were using catalytic amount $\left(10 \mathrm{~mol} \%\right.$ ) of $\mathrm{Cu}_{2} \mathrm{O}$, in the presence of $\mathrm{Cs}_{2} \mathrm{CO}_{3}$ as a base in $N, N$ dimethylacetamide (DMA) as solvent. The resulting mixture was then heated at $120{ }^{\circ} \mathrm{C}$ for $60 \mathrm{~min}$ in a microwave reactor leading to the desired products in moderate to very good yields, Scheme 3.
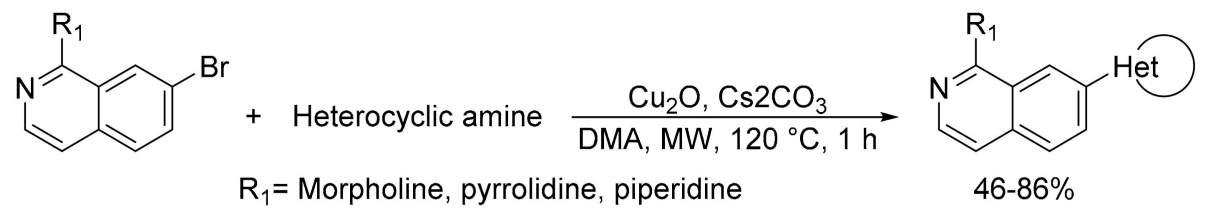

Scheme 3. $\mathrm{Cu}_{2} \mathrm{O}$ catalyzed microwave-assisted synthesis of arylated isoquinolines.

Similarly, Gavade, S.N. et al. has developed copper(I) oxide $\left(\mathrm{Cu}_{2} \mathrm{O}\right)$ as useful catalyst for the $N$-arylation of phenylurea to produce novel diphenylurea derivatives under microwave irradiation $[25,26]$. The diphenylurea compounds were obtained via $N$-arylation of phenylurea using aryl halides in the presence of catalytic amount (20 mol \%) of copper(I) oxide $\left(\mathrm{Cu}_{2} \mathrm{O}\right)$. Two protocols were published; first one using solvent- and ligand-free condition with the yields ranging from 35-90\% [25] and the second reaction condition was a ligand-free with the yields ranging from 60-85\% [26], Scheme 4.

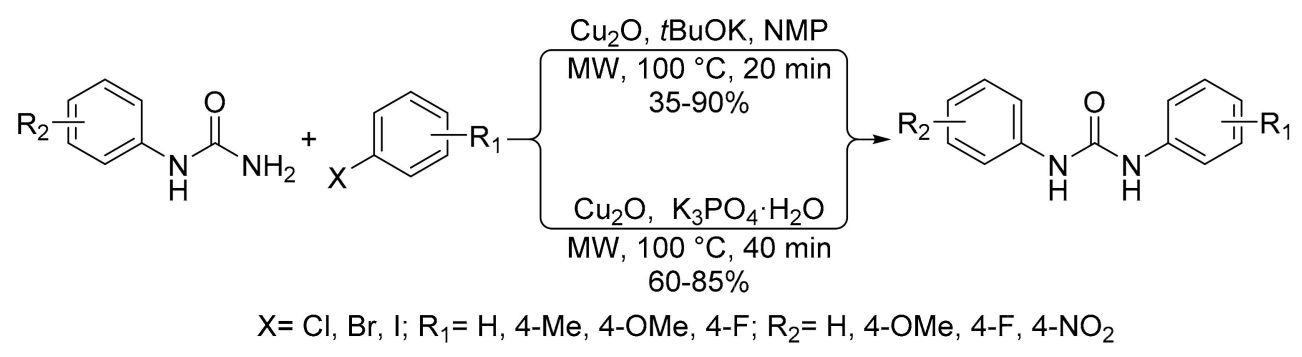

Scheme 4. $\mathrm{Cu}_{2} \mathrm{O}$ catalyzed microwave-assisted synthesis of diphenylurea. 
In another study utilizing microwave irradiation, Bolm and coworkers have reported on the amination reaction between of 3-halopyridines and amines as nucleophile under solvent- and ligand-free conditions that lead to novel $N$-heteroarylated derivatives of aniline at 3-position [27]. They have systematically examined different kind and amount of the copper catalysts and bases. The best reaction conditions was achieved when a catalytic amount $(10 \mathrm{~mol} \%)$ of copper(I) oxide $\left(\mathrm{Cu}_{2} \mathrm{O}\right)$ in the presence of $\mathrm{K}_{3} \mathrm{PO}_{4}$ as base was employed. The reaction mixture was then heated in a microwave oven at $100{ }^{\circ} \mathrm{C}$ for 60 min to obtain $N$-heteroarylated aniline derivatives in moderate to excellent yields, Scheme 5 .

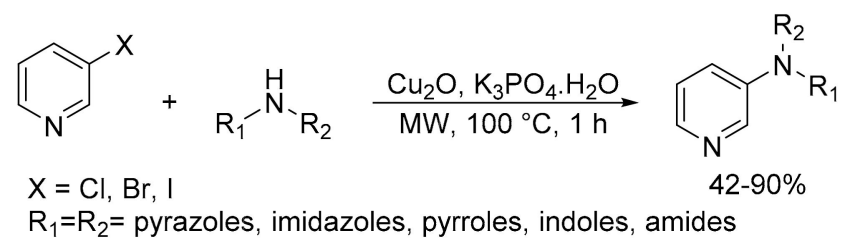

Scheme 5. $\mathrm{Cu}_{2} \mathrm{O}$ catalyzed microwave-assisted $\mathrm{N}$-arylation of 3-halopyridines.

In a microwave reactor, $\mathrm{Oh}$ and Yum have reported on the use of copper(I) oxide $\left(\mathrm{Cu}_{2} \mathrm{O}\right)$ to catalyze the synthesize of 1,3-diarylated indazoles [28]. They have reported on the use of catalytic amount $(10 \mathrm{~mol} \%)$ of $\mathrm{Cu}_{2} \mathrm{O}$, and $\mathrm{Cs}_{2} \mathrm{CO}_{3}$ as a base in $N, N$-dimethylacetamide (DMA) as solvent, the resulting mixture was then heated in a microwave oven at $200{ }^{\circ} \mathrm{C}$ for $1 \mathrm{~h}$, the optimized reaction conditions resulted in moderate to good yields, Scheme 6.

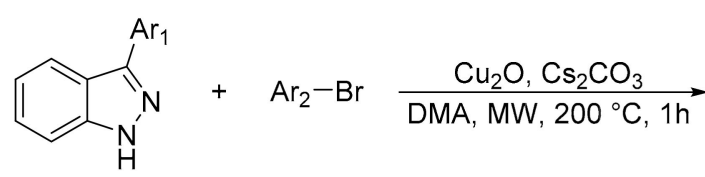

$\mathrm{Ar}_{1}=\mathrm{C}_{6} \mathrm{H}_{5}$, Thiophene, Pyridine, Thianaphthene $\mathrm{Ar}_{2}=\mathrm{H}, 4-\mathrm{MeC}_{6} \mathrm{H}_{4}, 3-\mathrm{OMeC}_{6} \mathrm{H}_{4}, 3,4-\mathrm{DiOMeC}_{6} \mathrm{H}_{3}$, Pyridine<smiles>[Y10]n1nc(Br)c2ccccc21</smiles>

$39-71 \%$

Scheme 6. $\mathrm{Cu}_{2} \mathrm{O}$ catalyzed microwave-assisted $\mathrm{N}$-arylation of 3-arylindazoles.

Under controlled microwave technology, Sakhuja and coworkers have reported on the synthesis of $N$-coumaryl amino acids by coupling reaction between 4-chlorocoumarin with $N$-terminus unprotected amino acids following the Ullmann coupling reaction, the optimized reaction condition suggest the use of copper(I) iodide (CuI) in basic condition $\left(\mathrm{K}_{2} \mathrm{CO}_{3}\right)$ and water as solvent [29]. The resulting mixture was then heated in a microwave oven at $80{ }^{\circ} \mathrm{C}$ for $10-15$ min to produce a series of $N$-coumaryl amino acids in very high yields, Scheme 7.

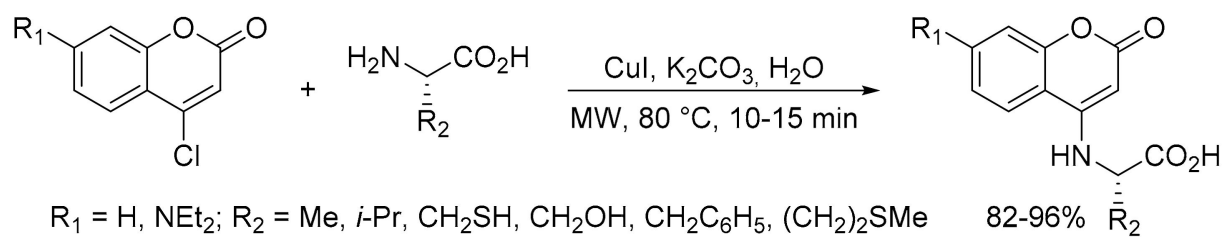

Scheme 7. CuI catalyzed microwave-assisted reaction between 4-chlorocoumarin and amino acids.

Recently, Kwon, J.-K. et al. have developed a simple and efficient copper(I) oxide $\left(\mathrm{Cu}_{2} \mathrm{O}\right)$ catalyst system for the $N$-arylation reaction of various indole derivatives with divers aryl halides (Ar-X) under microwave irradiation technology [30]. The reaction has been optimized with regards copper salts, bases and solvents. The most effective reaction condition was achieved by the use of catalytic amount (10 mol \%) of $\mathrm{Cu}_{2} \mathrm{O}$ and cesium carbonate $\left(\mathrm{Cs}_{2} \mathrm{CO}_{3}\right)$ as base in dimethylacetamide (DMA) as solvent to produce the 
desired products, $N$-heteroarylated indoles, in moderate to excellent yields via ligand-free copper-catalyzed Ar-N bond formation. The reaction carried out in a microwave oven at $200{ }^{\circ} \mathrm{C}$ for $20-60 \mathrm{~min}$, Scheme 8 .

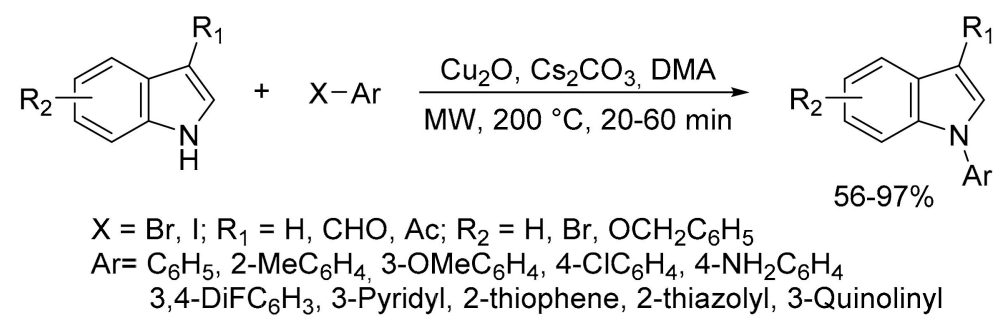

Scheme 8. $\mathrm{Cu}_{2} \mathrm{O}$ catalyzed microwave-assisted synthesis of $\mathrm{N}$-aryl indoles.

Scheme 9 summarizes the proposed mechanism for Ullmann-type cross-coupling reaction. In the first step copper $(\mathrm{I})$ halide $(\mathrm{Cu}-\mathrm{X})$ react with a nucleophile $(\mathrm{HNu})$ in the presence of base to facilitate the removal of the acid (HX). This step will lead for the formation of a complex between copper and nucleophile $(\mathrm{Cu}-\mathrm{Nu})$. Followed by an oxidative addition of aryl halide (Ar-X), which proceed via the accommodation of Ar and X functions on the catalyst surface through oxidizing $\mathrm{Cu}(\mathrm{I})$ to $\mathrm{Cu}(\mathrm{III})$. Copper(III) is unstable species and will undergo a reductive elimination reaction to produce the Ullmann coupling product and to regenerate the catalyst $(\mathrm{Cu}-\mathrm{X})$ to be reused in the next catalytic cycle.

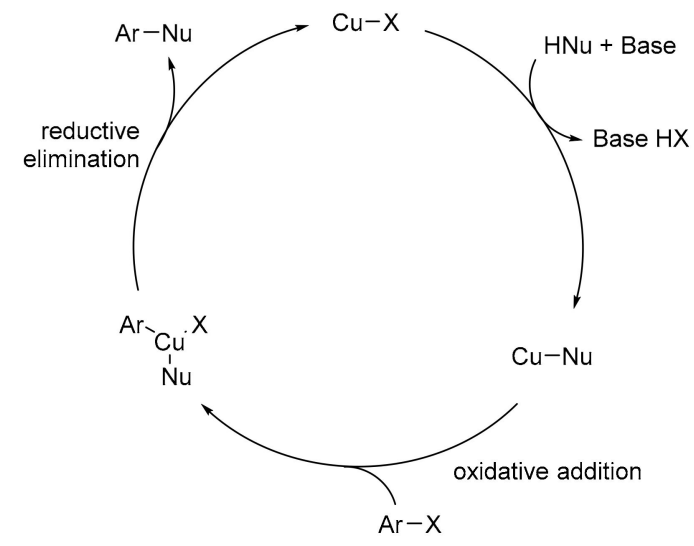

Scheme 9. A proposed mechanism pathway for the Ullmann-type cross-coupling reaction.

\subsection{Azide-Alkyne Huisgen [2 + 3] Cycloaddition Reaction}

The azide-alkyne Huisgen $(3+2)$ cycloaddition is one of the most versatile synthetic methods in heterocyclic chemistry. It is a 1,3-dipolar cycloaddition reaction between an organoazides $\left(R-N_{3}\right)$ and a terminal or internal alkyne $(C \equiv C)$ to produce mixtures of the two regioisomers when using asymmetric alkynes. In this respect, the classic Huisgen $(3+2)$ cycloaddition fails as a true click reaction. A copper-catalyzed variant can be conducted in aqueous conditions, even at room temperature. Additionally, whereas the classic Huisgen 1,3-dipolar cycloaddition often produces mixtures of regioisomers, the copper-catalyzed reaction allows the synthesis of the 1,4-disubstituted regioisomers specifically [31].

Under controlled microwave irradiation condition, Raju and coworkers have developed new derivatives of 1,2,3-triazolyl-pyrrolidinyl-quinolinolines using copper as catalysts and evaluated these derivatives for their antibacterial activity [32]. They have examined two oxidation state of copper, namely copper(I) iodide (CuI) and copper(II) sulfate pentahydrate $\left(\mathrm{CuSO}_{4} \cdot 5 \mathrm{H}_{2} \mathrm{O}\right)$. $\mathrm{CuI}$ found to be superior with respect to yields, in which the desired products were obtained in very good to excellent yield, Scheme 10. 


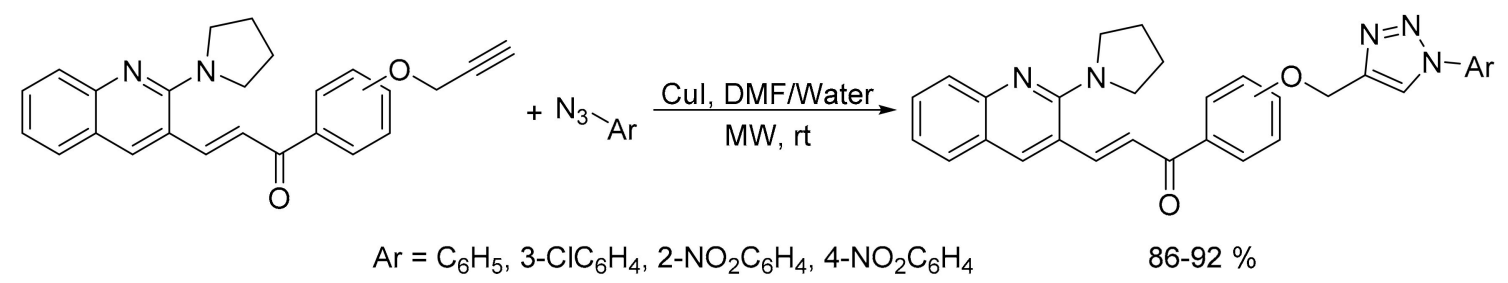

Scheme 10. Synthesis of 1,2,3-triazolyl-pyrrolidinyl-quinolinolines under microwave condition.

In another study utilizing microwave irradiation, Arrjane, M. et al. have synthesized and evaluated new acridone derivatives as antibacterial agent, in vitro [33]. The proposed derivatives were prepared via click chemistry using copper sulfate pentahydrate $\left(\mathrm{CuSO}_{4} \cdot 5 \mathrm{H}_{2} \mathrm{O}\right)$ and sodium ascorbate $(\mathrm{VcNa})$ in DMF as solvent. The reaction was performed in conventional and microwave heating. The authors have concluded that the use of microwave irradiation has dramatically reduced the reaction time to 10 min with great improvements in the yields, Scheme 11.<smiles>[R]c1ccc(NC(=O)CN)cc1</smiles>

$\mathrm{R}_{1}=\mathrm{H}, \mathrm{CH}_{3} ; \mathrm{R}_{2}=\mathrm{H}, 4-\mathrm{CH}_{3}, 2-\mathrm{CH}_{3}, 4-\mathrm{CO}_{2} \mathrm{H}$

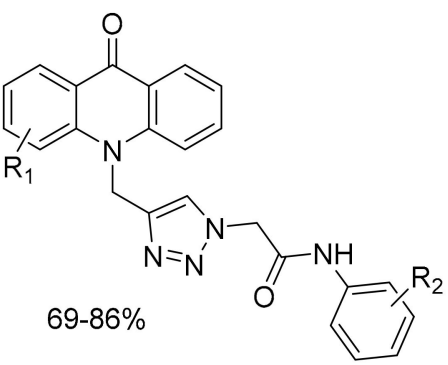

Scheme 11. $\mathrm{CuSO}_{4} \cdot 5 \mathrm{H}_{2} \mathrm{O}$ catalyzed microwave-assisted synthesis of acridone-1,2,3-triazole derivatives.

A microwave-assisted protocol for the synthesis of 7-triazol-1-yl-fluoroquinolone using copper(II) sulfate $\left(\mathrm{CuSO}_{4}\right)$ as catalyst for the azide-alkyne cycloaddition has been proposed by Cardoso-Ortiz and coworkers [34]. Two reaction procedures were employed, one under conventional heating, while the other one performed under microwave irradiation. It has been noticed that the extended reaction time, under conventional heating, for 7 days were accomplished in very short time (ca. $5 \mathrm{~min}$ ) under microwave irradiation, with significant improvement in the yield of the desired product, Scheme 12.<smiles></smiles><smiles>[R]c1cn(-c2c(F)cc3c(=O)c(C(=O)OCC)cn(CC)c3c2[R])nn1</smiles>

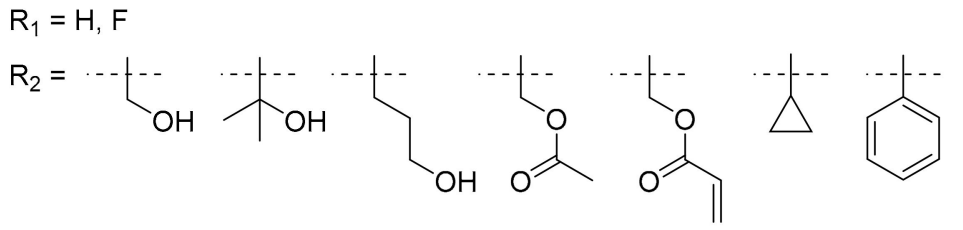<smiles>COC(=O)c1ccc(OCC(C)(C)C)cc1</smiles>

Scheme 12. $\mathrm{CuSO}_{4}$ catalyzed microwave-assisted synthesis of 7-triazol-1-yl-fluoroquinolones.

Lima and coworkers have developed novel copper-II oxide nanoparticles (CuO NPs) to catalyze the synthesis of 1,2,3-triazoles starting from divers dicarbonyl compounds and aryl azides under microwave technology [35]. The reaction proceed using a catalytic amount (30 mol \%) of the copper nanoparticles (CuO NPs) in dimethyl sulfoxide (DMSO) 
as solvent, the resulting mixture was then heated in a microwave oven at $80{ }^{\circ} \mathrm{C}$ for $15 \mathrm{~min}$ to produce 1,4,5-trisubstituted 1,2,3-triazoles in low to excellent yields, Scheme 13.

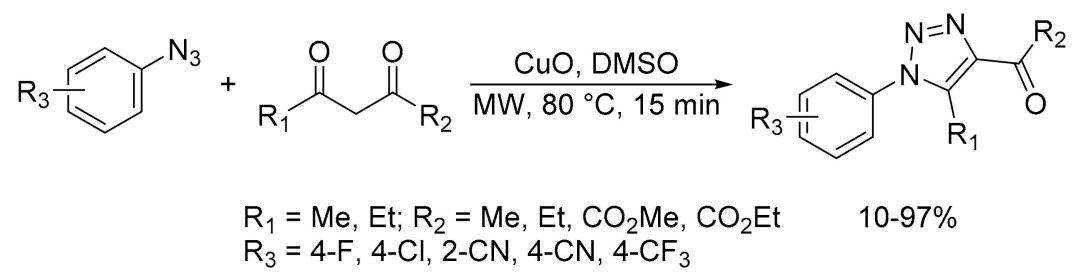

Scheme 13. CuO NPs catalyzed microwave-assisted synthesis of 1,4,5-trisubstituted 1,2,3-triazoles.

Under controlled microwave irradiation conditions, Ashok and coworkers have developed new 2-indolinone-based bis-1,2,3-triazole derivatives as antioxidant and antimicrobial agents [36]. The chemical syntheses were performed in direct comparison between conventional and microwave heating in the presence of two oxidation state of copper catalysts (I \& II), namely copper(I) iodide (CuI) with sodium ascorbate ( $\mathrm{VcNa}$ ) and copper(II) sulfate pentahydrate $\left(\mathrm{CuSO}_{4} \cdot 5 \mathrm{H}_{2} \mathrm{O}\right)$. CuIfound to be superior over $\mathrm{CuSO}_{4} \cdot 5 \mathrm{H}_{2} \mathrm{O}$ that produces the desired products in higher yields. Both reactions were achieved in short reaction times (3-12 min), Scheme 14.

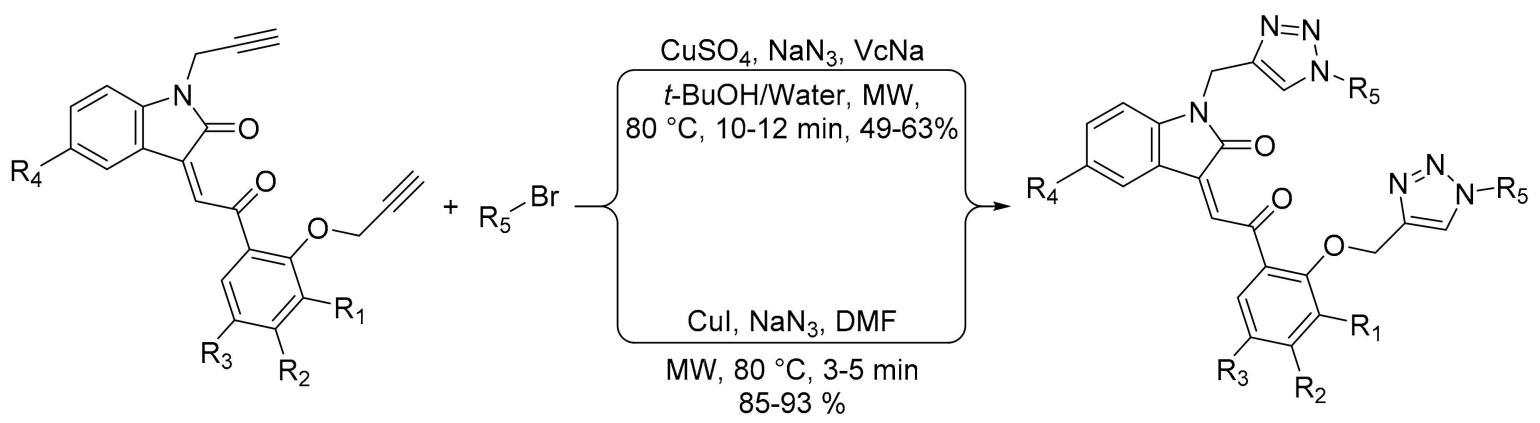

Scheme 14. Copper salt catalysts promote microwave-assisted synthesis of 2-indolinone-based bis-1,2,3-triazole derivatives.

Four novel hydrosoluble $\mathrm{Cu}(\mathrm{I})$-DAPTA complexes have been synthesized and characterized for their efficiency in a microwave-assisted three-component azide-alkyne cycloaddition click reaction [37]. One of these novel catalysts found to be more effective that leads to higher yields of the desired products. The reaction mixture was heated in a microwave oven at $125{ }^{\circ} \mathrm{C}$ for $15 \mathrm{~min}$ in mixture of equal amount (1:1) of water and acetonitrile as solvent furnishing the desired products in good to excellent yields, Scheme 15.

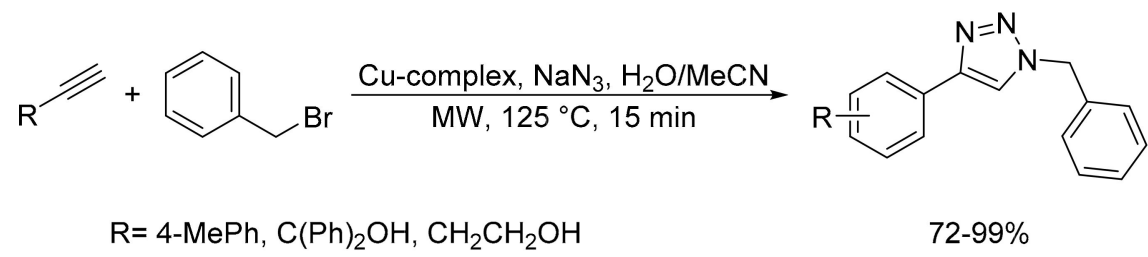

Scheme 15. $\mathrm{Cu}(\mathrm{I})$-DAPTA catalyzed three-component azide-alkyne cycloaddition click reaction.

Using a dedicated microwave oven, Yuan and Qu have reported on the functionalization of $\beta$-sitosterols [38]. In which a mixture of $\beta$-sitosterol-3-yl azide, phenylacetylene, catalytic amount $(10 \mathrm{~mol} \%)$ of $\mathrm{CuSO}_{4} \cdot 5 \mathrm{H}_{2} \mathrm{O}$ and sodium L-ascorbate $(\mathrm{VcNa})$, were all mixed in the presence of water as solvent. The resulting mixture was then heated in a microwave oven as $40^{\circ} \mathrm{C}$ for $30 \mathrm{~min}$, to produce the desired product in low to excellent isolated yields, Scheme 16 . 


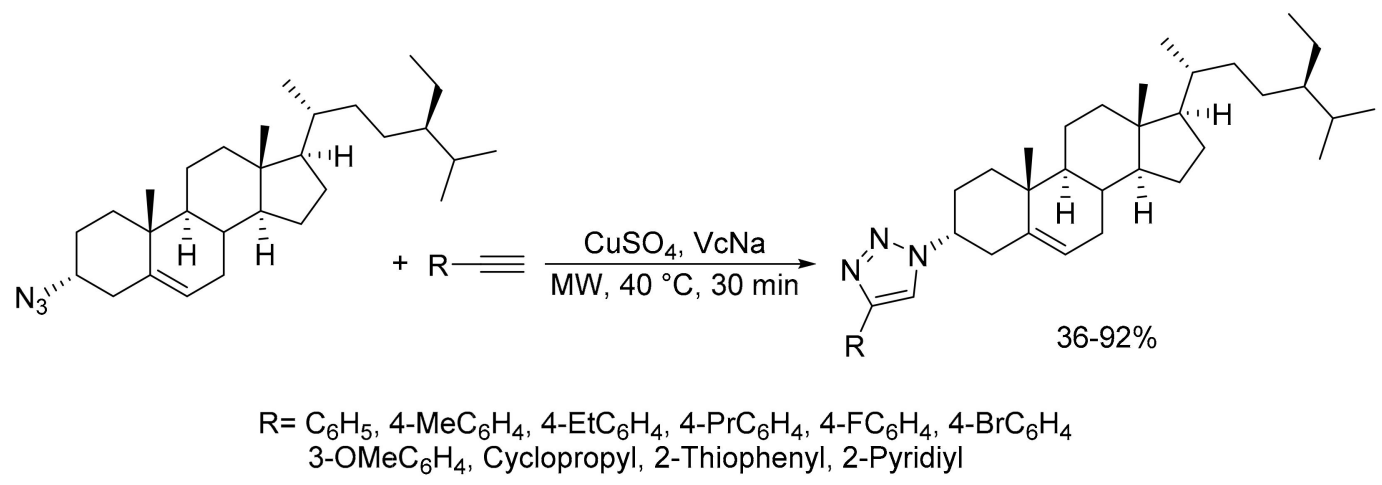

Scheme 16. $\mathrm{CuSO}_{4}$ catalyzed microwave-assisted synthesis of $\beta$-sitosterol derivatives bearing a 1,2,3-triazole substituents.

Alves and coworkers have reported on the synthesis of (arylselanyl)phenyl-1H-1,2,3triazoles under copper catalyzed microwave assisted reaction [39]. The reaction proceed with excellent yield when they used copper(II) acetate $\left(\mathrm{Cu}(\mathrm{OAc})_{2}\right)$ and sodium ascorbate in a mixture of water and THF, the mixture was heated in a microwave oven at $70{ }^{\circ} \mathrm{C}$ for 30 min to produce the target compound in excellent yield, Scheme 17.

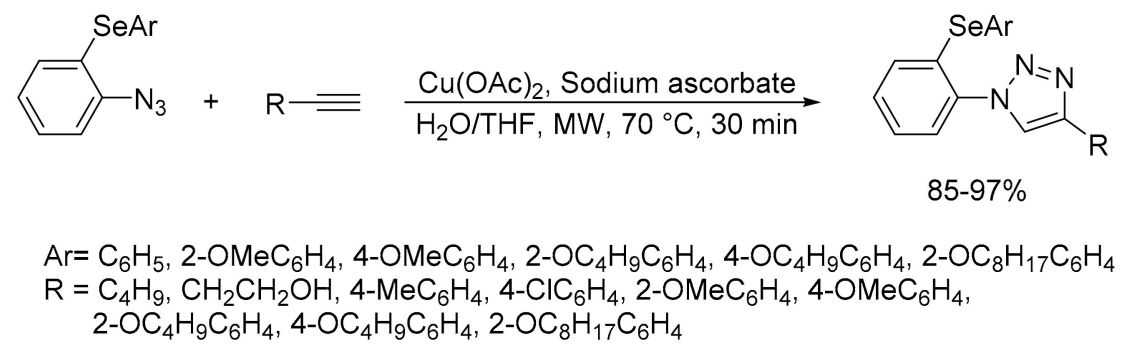

Scheme 17. $\mathrm{Cu}(\mathrm{OAc})_{2}$ catalyzed microwave assisted synthesis of (arylselanyl)phenyl-1H-1,2,3triazoles.

Using a microwave-assisted protocol, Van der Eycken and coworkers have systematically improved the construction of 2-amino- $1 \mathrm{H}$-imidazole/triazole conjugates, the target compounds showed moderate to high preventive activity against biofilms of $S$. Typhimurium, E. coli, P. aeruginosa, and S. aureus. [40]. They have optimized the synthesis using a catalytic amount ( $5 \mathrm{~mol} \%$ ) of copper(II) acetate nanoparticles [Cu(OAc) $)_{2} \mathrm{NPs}$ ] to catalyze the azide-alkyne cycloaddition in the presence of hydrazine $\left(\mathrm{N}_{2} \mathrm{H}_{4}\right)$ as solvent, the resulting mixture was then heated in a microwave oven at $100{ }^{\circ} \mathrm{C}$ for short reaction time ( $2 \mathrm{~min}$ ) to produce 2-amino- $1 \mathrm{H}$-imidazole/triazole conjugates in moderate to excellent yield, Scheme 18.

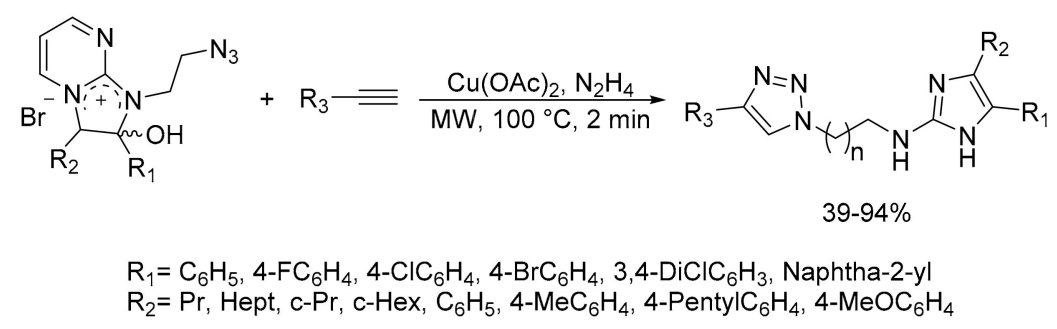

Scheme 18. $\mathrm{Cu}(\mathrm{OAc})_{2} \mathrm{NPs}$ catalyzed microwave-assisted synthesis of 2-amino- $1 \mathrm{H}$-imidazole/ triazole conjugates.

In another study utilizing microwave irradiation, Carvalho and coworkers have reported on the use of copper(II) sulfate $\left(\mathrm{CuSO}_{4}\right)$ to catalyze the cycloaddition reaction between azide and alkyne [41]. The reaction was achieved using catalytic amount ( $3 \mathrm{~mol} \%)$ of $\mathrm{CuSO}_{4}$ and DMF as solvent, the resulting mixture was then heated in microwave oven 
at $70{ }^{\circ} \mathrm{C}$ for $10 \mathrm{~min}$ to produce benznidazole derivatives in moderate to excellent yields, Scheme 19.

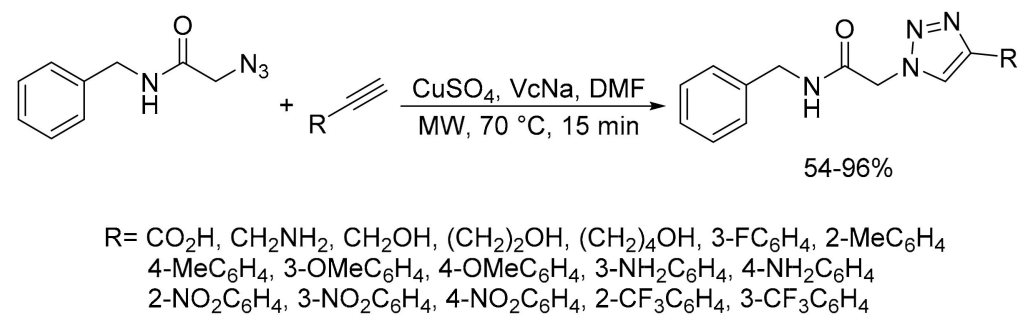

Scheme 19. $\mathrm{CuSO}_{4}$ catalyzed microwave-assisted synthesis of benznidazole analogues.

In a systematic investigation using microwave technology, Khan, A.N. et al. has reported on the use of copper salts to catalyze the synthesis of $\beta-1,2,3$-triazolyl- $\alpha$-amino esters [42]. They have reported on the use of several kind of copper catalysts in different solvents and in the presence or absence of the base pentamethyldiethylenetriamine (PMDTA). A catalytic amount (10 mol \%) of copper(I) iodide (CuI) in the presence of PMDTA in THF were the most effective combination. The reaction mixture was then heated in a microwave oven at $100{ }^{\circ} \mathrm{C}$ for short reaction time ( $5 \mathrm{~min}$ ), to offer $\beta$-1,2,3-triazolyl- $\alpha$-amino esters in moderate to good isolated yields, Scheme 20.

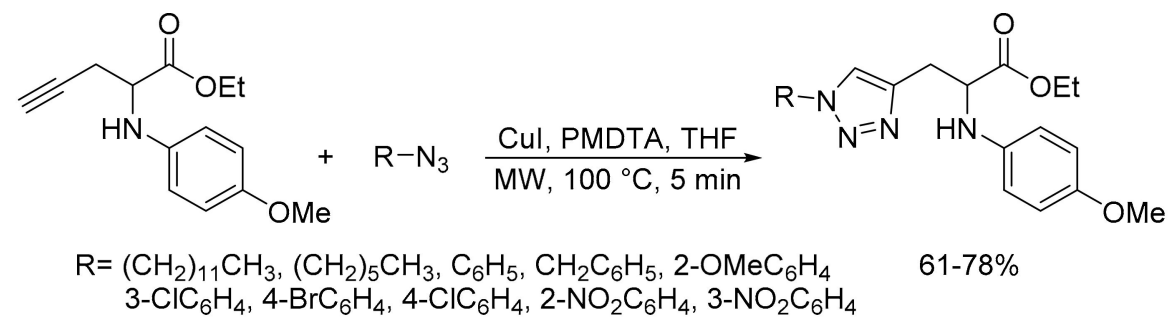

Scheme 20. CuI catalyzed microwave-assisted synthesis of $\beta-1,2,3$-triazolyl- $\alpha$-amino esters.

Under microwave assisted reaction conditions, Liu and coworkers have reported on the use of copper(II) sulfate to catalyze the one-pot synthesis of $\alpha$-propargyl 3-tosylamino2,3-dideoxyglycosides [43]. A systematic strategy were employed to access these very important kind of organic molecules. They have concluded that the most effective reaction pathway found to be the use of a catalytic amount ( $1 \mathrm{~mol} \%$ ) of $\mathrm{CuSO}_{4}$ in DMF as solvent, the reaction mixture was then heated in a microwave oven at $70{ }^{\circ} \mathrm{C}$ for $15 \mathrm{~min}$, the desired products were obtained in moderate to excellent yields, Scheme 21.

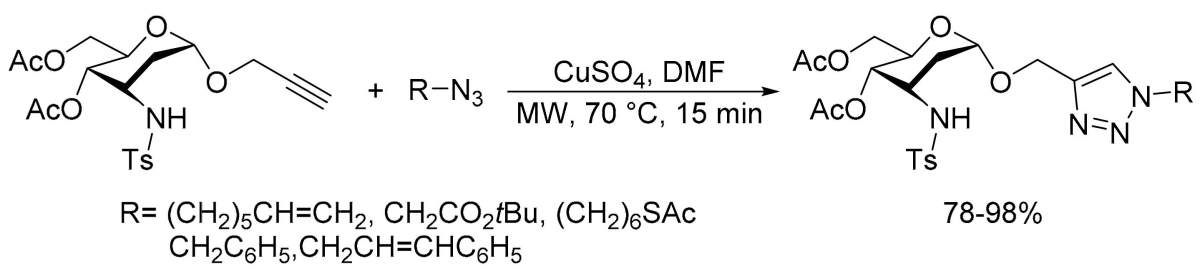

Scheme 21. $\mathrm{CuSO}_{4}$ catalyzed microwave assisted synthesis of $\alpha$-propargyl 3-tosylamino-2,3dideoxyglycosides.

In another study by Barros and coworkers reported on the derivatization of sucrose were sucrose derived azides reacted with diverse terminal alkynes to produce 1,2,3-triazolesucrose derivatives [44]. They have reported on the use of catalytic amount $(20 \mathrm{~mol} \%)$ of copper sulfate $\left(\mathrm{CuSO}_{4}\right)$ in the presence of sodium ascorbate $(\mathrm{VcNa})$ in equal amount $(1: 1)$ of tert-butanol and water $\left(t \mathrm{Bu}: \mathrm{H}_{2} \mathrm{O}\right)$, the resulting mixture was then heated in a microwave oven at $70{ }^{\circ} \mathrm{C}$ for a short reaction time $(5 \mathrm{~min})$, and 1,2,3-triazole-sucrose derivatives were produced in excellent yields, Scheme 22. 


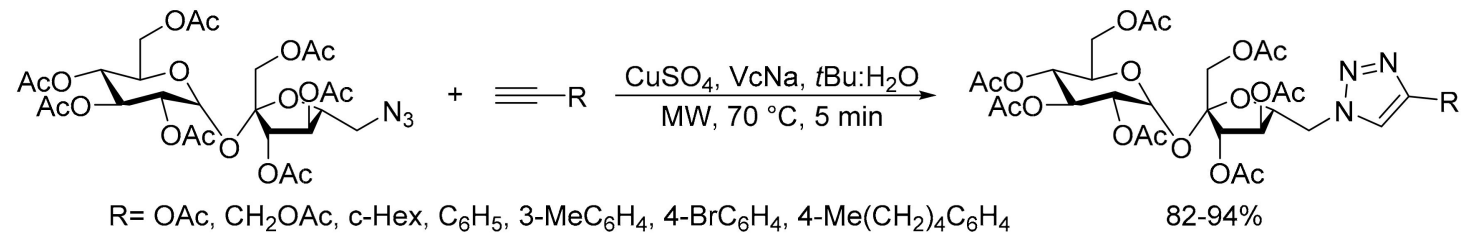

Scheme 22. $\mathrm{CuSO}_{4}$ catalyzed microwave assisted synthesis of 1,2,3-triazole-sucrose derivatives.

The copper(I)-catalyzed azide-alkyne cycloaddition (CuAAC) has gained widespread attention since its first postulation in 2001 as a facile synthetic methodology for the generation of new covalent bonds in a variety of environments. Fokin and coworkers proposed the involvement of two copper atoms within the active cycloaddition complex (Scheme 23) [45].

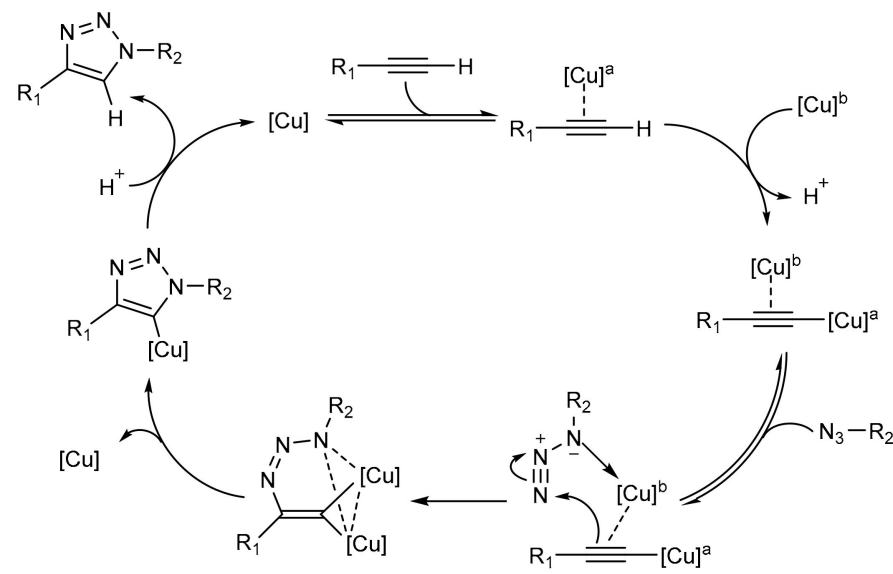

Scheme 23. Proposed catalytic model for the CuAAC with two copper atoms.

\subsection{Carbon-Carbon $(\mathrm{C}-\mathrm{C})$ Bond Formation}

Copper and its salts have been widely involved as co-catalyst along with palladium for the Heck and Sonogashira coupling reactions furnishing carbon-carbon $(\mathrm{C}-\mathrm{C})$ bond. For example palladium/copper-II oxide nanoparticles ( $\mathrm{Pd} / \mathrm{CuO} \mathrm{NPs}$ ) were developed and widely used for the Heck coupling reactions under microwave irradiation [46]. The reaction was performed using catalytic amount $(2 \mathrm{~mol} \%)$ of $\mathrm{Pd} / \mathrm{CuO}$ in the presence of base $\left(\mathrm{K}_{2} \mathrm{CO}_{3}\right)$ and equal volume (1:1) of ethanol/water as solvent, the reaction mixture was then heated in a microwave oven at $150{ }^{\circ} \mathrm{C}$ for a short reaction time $(10 \mathrm{~min})$ to produce the desired products in good to excellent yield, Scheme 24.

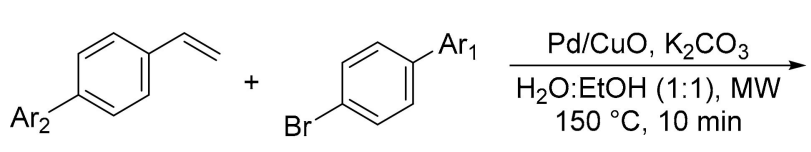

$\mathrm{Ar}_{1}=\mathrm{CN}, \mathrm{OMe}, \mathrm{CO}_{2} \mathrm{H}, \mathrm{CHO} ; \mathrm{Ar}_{2}=t-\mathrm{Bu}, \mathrm{H}, \mathrm{Cl}, \mathrm{F}$<smiles>CCCc1ccc(/C=C/c2ccc(Br)cc2)cc1</smiles>

$75-93 \%$

Scheme 24. Pd/CuO NPs catalyzed microwave-assisted Heck coupling reaction.

The authors have employed the same catalyst (Pd/CuO NPs) under microwave irradiation conditions to explore its efficiency towards the Sonogashira coupling between phenylacetylene and iodobenzene [47]. The catalyst found to be effective for the synthesis of diphenylacetylene in high yield, Scheme 25. 


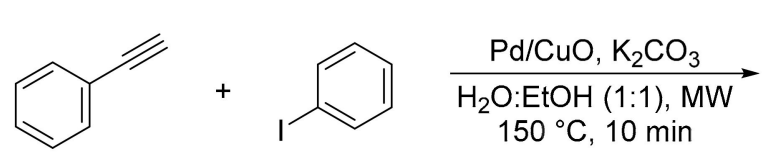

$150{ }^{\circ} \mathrm{C}, 10 \mathrm{~min}$

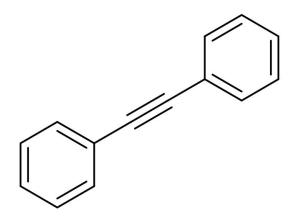

$88 \%$

Scheme 25. Pd/CuO NPs catalyzed microwave-assisted Sonogashira coupling reaction.

Tsai, W.-T. et al. improved the coupling reaction between aryl halides, vinyl iodides, and bromides with aryl- and alkyl-alkynes under controlled microwave irradiation condition [48]. The reaction was proceed using catalytic amount (2-5 mol \%) of the copper complex $[\mathrm{CuI}($ xantphos $)]$ in the presence of cesium carbonate $\left(\mathrm{Cs}_{2} \mathrm{CO}_{3}\right)$ as base in DMF as solvent, the resulting mixture was then heated in a microwave oven at $135{ }^{\circ} \mathrm{C}$ for $10-30 \mathrm{~min}$, furnishing the desired alkyne derivatives in low to excellent isolated yields, Scheme 26.

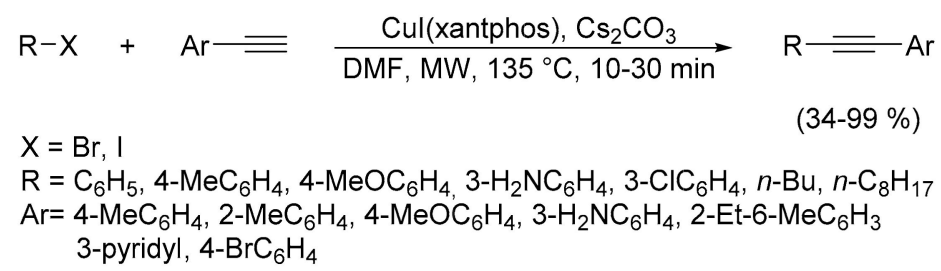

Scheme 26. CuI(xantphos) catalyzed microwave-assisted Sonogashira coupling reaction.

In another study utilizing copper/palladium to catalyze Sonogashira cross-coupling reaction between aryl halides and trimethylsilylacetylene has been described by Lei, Y. et al. [49]. The reaction was optimized utilizing a catalytic amount (10 mol \%) of copper $(\mathrm{I})$ iodide $(\mathrm{CuI})$, triethylamine $\left(\mathrm{Et}_{3} \mathrm{~N}\right)$ as base in acetonitrile as solvent, the resulting mixture was then heated in a microwave oven at $120^{\circ} \mathrm{C}$ for a short reaction time ( $\left.5 \mathrm{~min}\right)$ leading to the desired products in high yields, Scheme 27.

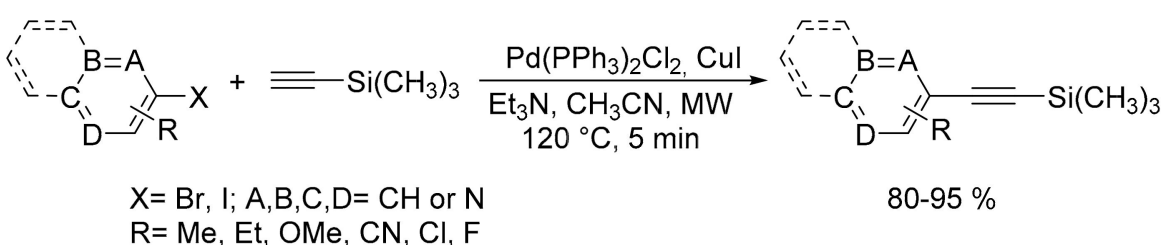

Scheme 27. $\mathrm{Cu} / \mathrm{Pd}$-catalyzed microwave-assisted Sonogashira-type coupling reaction between aryl halide and trimethylsilylacetylene.

Under controlled microwave process, Anilkumar and coworkers have developed environmentally friendly catalytic method of copper based catalyst to catalyze Suzuki cross-coupling reaction of alkynyl bromides with boronic acid derivatives [50]. The Suzukitype reaction proceed smoothly using a catalytic amount (10 mol \%) of copper(I) iodide $(\mathrm{CuI})$ in the presence of potassium phosphate $\left(\mathrm{K}_{3} \mathrm{PO}_{4}\right)$ as base and ethanol as solvent, the combined mixture was then heated in a microwave oven at $130{ }^{\circ} \mathrm{C}$ for $15 \mathrm{~min}$ furnishing 1,2-diarylacetylenes in moderate to excellent yield, Scheme 28.

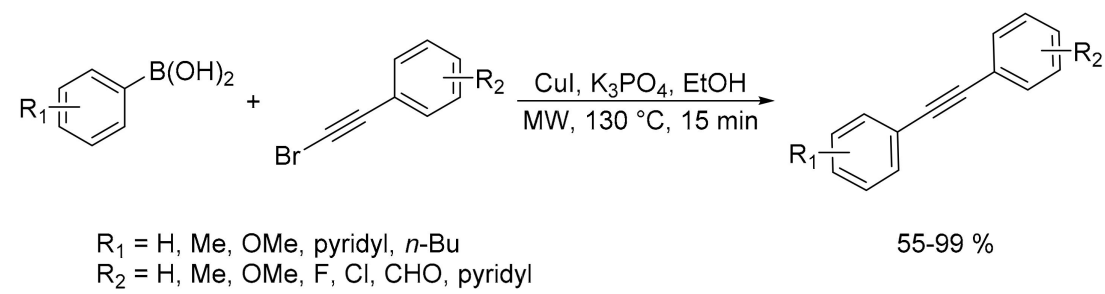

Scheme 28. CuI catalyzed microwave-assisted Suzuki-type synthesis of 1,2-diarylacetylenes. 
Bimetallic catalysts composed of palladium and copper(II) oxide $(\mathrm{Pd} / \mathrm{CuO})$ have been developed by Elazab, H.A. et al. as efficient and recyclable catalyst for the Suzuki-type cross-coupling reaction [50]. The reaction proceed using a catalytic amount (1 mol \%) of $\mathrm{Pd} / \mathrm{CuO}$ in the presence of potassium carbonate $\left(\mathrm{K}_{2} \mathrm{CO}_{3}\right)$ as base and in equal amount (1:1) of water and ethanol $\left(\mathrm{H}_{2} \mathrm{O}: \mathrm{EtOH}\right)$ as solvent, the reaction mixture was then heated in a microwave oven at $150^{\circ} \mathrm{C}$ for 10 min furnishing biphenyl derivatives in moderate to excellent yields, Scheme 29. The developed Suzuki coupling reaction found to be applicable for a wide varieties of aryl halides and the desired products were obtained in good to excellent yields. It has been also noticed that the catalyst can be fully recycled up to five times while keeping its efficiency.

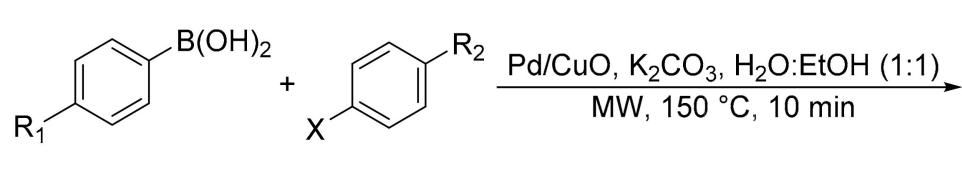

$\mathrm{X}=\mathrm{I}, \mathrm{Br}, \mathrm{Cl} ; \mathrm{R}_{1}=\mathrm{NEt}_{2}$, SMe, OEt, OMe; $\mathrm{R}_{2}=\mathrm{H}, \mathrm{OMe}, \mathrm{CN}, \mathrm{NO}_{2}$<smiles>[R]c1ccc(-c2ccc([R])cc2)cc1</smiles>

$60-91 \%$

Scheme 29. Pd/CuO catalyzed microwave-assisted Suzuki cross-coupling reaction.

Using microwave technology, Ibrahim, M.A. has reported the use of copper(II) triflate $\mathrm{Cu}(\mathrm{OTf})_{2}$ for the coupling reaction between a wide range of aryl halides and diethyl malonate esters furnishing $\alpha$-aryl malonates, as important intermediate in the synthesis of azaheterocycles, such as benzodiazepine, isoquinoline, and pyrrolopyridine derivatives [51]. The reaction have been properly optimized to use catalytic amount (10 mol \%) of $\mathrm{Cu}(\mathrm{OTf})_{2}$, picolinic acid as ligand and toluene as solvent, the resulting mixture was then heated in a microwave oven at $90{ }^{\circ} \mathrm{C}$ for $20 \mathrm{~min}$ to obtain $\alpha$-aryl malonates in moderate to excellent yields, Scheme 30.

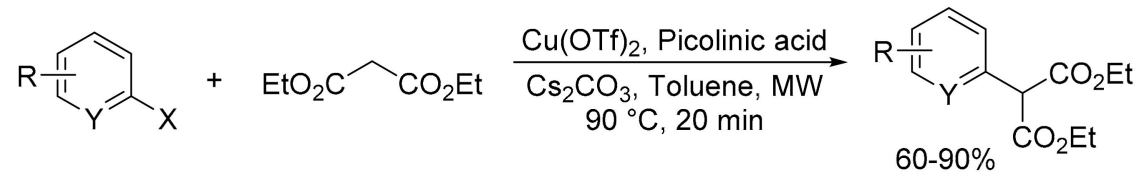

$\mathrm{R}=\mathrm{H}, \mathrm{Me}, \mathrm{NO}_{2}, \mathrm{Cl},(\mathrm{CO} 2 \mathrm{Et})_{2}, \mathrm{CN}, \mathrm{CO}_{2} \mathrm{Me}, \mathrm{C}_{6} \mathrm{H}_{5} \mathrm{CO}, 4-\mathrm{MeOC}_{6} \mathrm{H}_{4} \mathrm{CO}$

Scheme 30. $\mathrm{Cu}(\mathrm{OTf})_{2}$ catalyzed microwave-assisted synthesis of $\alpha$-aryl malonates.

Under controlled microwave irradiation conditions, Jha and Jain described a regioselective cross-coupling reaction of $\mathrm{N}$-tosylhydrazones with azine $\mathrm{N}$-oxides [52]. The reaction proceed using copper(I) iodide (CuI) and $\mathrm{LiO} t \mathrm{Bu}$ as a base in toluene as solvent, the resulting mixture was then irradiated in a microwave reactor at $100{ }^{\circ} \mathrm{C}$ for $60 \mathrm{~min}$ and the desired products were obtained in moderate to excellent yields, Scheme 31.

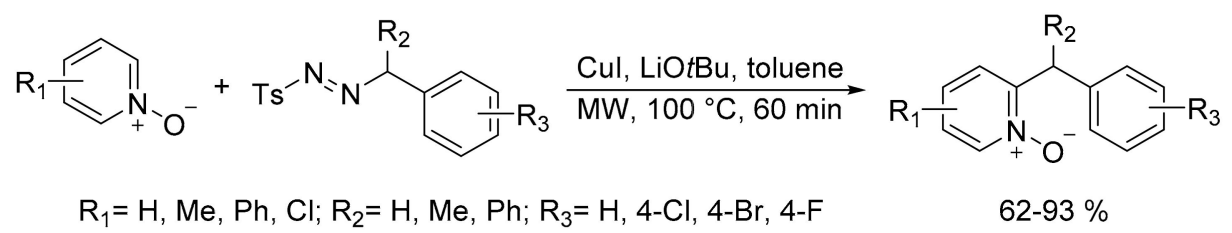

Scheme 31. CuI catalyzed microwave-assisted synthesis of ortho-alkylated derivatives.

\subsection{Synthesis of Propargylamines}

Propargylamines are versatile building blocks and key intermediates for the synthesis of important scaffolds bearing nitrogen function, such as natural products, heterocycles, and biologically active molecules [53]. Therefore, scientists are interested in the development of new methods for the synthesis of this important class of intermediates [54-57]. The 
synthesis started under classical pathway followed by transition-metal-catalyzed threecomponent coupling reactions under conventional heating. While, in the last decade, more emphasize was given for the preparation of propargylamines under microwave irradiation, including the use of copper to catalyze their syntheses. One of the most convenient and general approach to produce propargylamine derivatives is the three-component coupling of an amine, an aldehyde, and an alkyne, commonly called $\mathrm{A}^{3}$ coupling.

Van der Eycken and co-workers described the synthesis of secondary alkylpropargylamines via $\mathrm{A}^{3}$ coupling reaction with primary aliphatic amines under microwave heating [56]. A catalytic amount ( $20 \mathrm{~mol} \%$ ) of copper(I) iodide (CuI) was used for the three component cross-coupling reaction among cyclic ketone, primary amine, and terminal alkyne under solvent free condition, the resulting mixture was then heated in a microwave oven at $100{ }^{\circ} \mathrm{C}$ for $25 \mathrm{~min}$ to produce propargylamine derivatives from low to very good yields, Scheme 32.

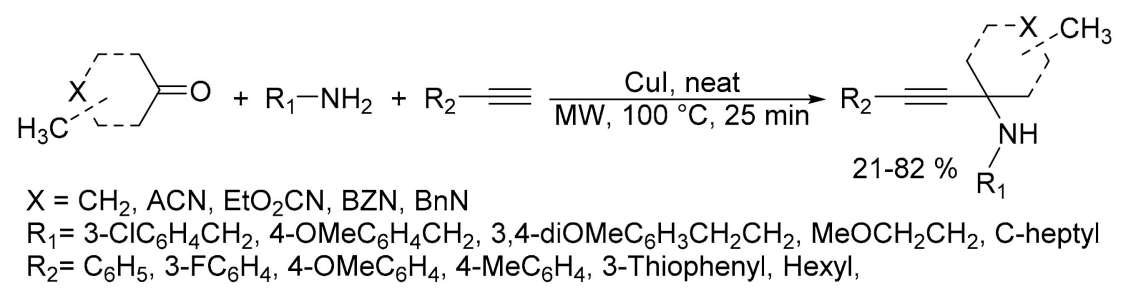

Scheme 32. CuI catalyzed microwave-assisted $\mathrm{A}^{3}$ coupling for the synthesis of propargylamines.

Shimpi and coworkers have developed new heterogeneous catalyst (CuNPs@ZnOPTh) which composed of copper nanoparticles (CuNPs) loaded on zinc oxide-polythiophene (ZnO-PTh) [58]. The catalyst then applied to the synthesis of number of propargylamine derivatives, such as tetra substituted propargylamine and pyrrolo [1,2-a]quinolone in ethylene glycol as a solvent and heated in a dedicated microwave reactor, the desired products were obtain in high yields, Scheme 33.

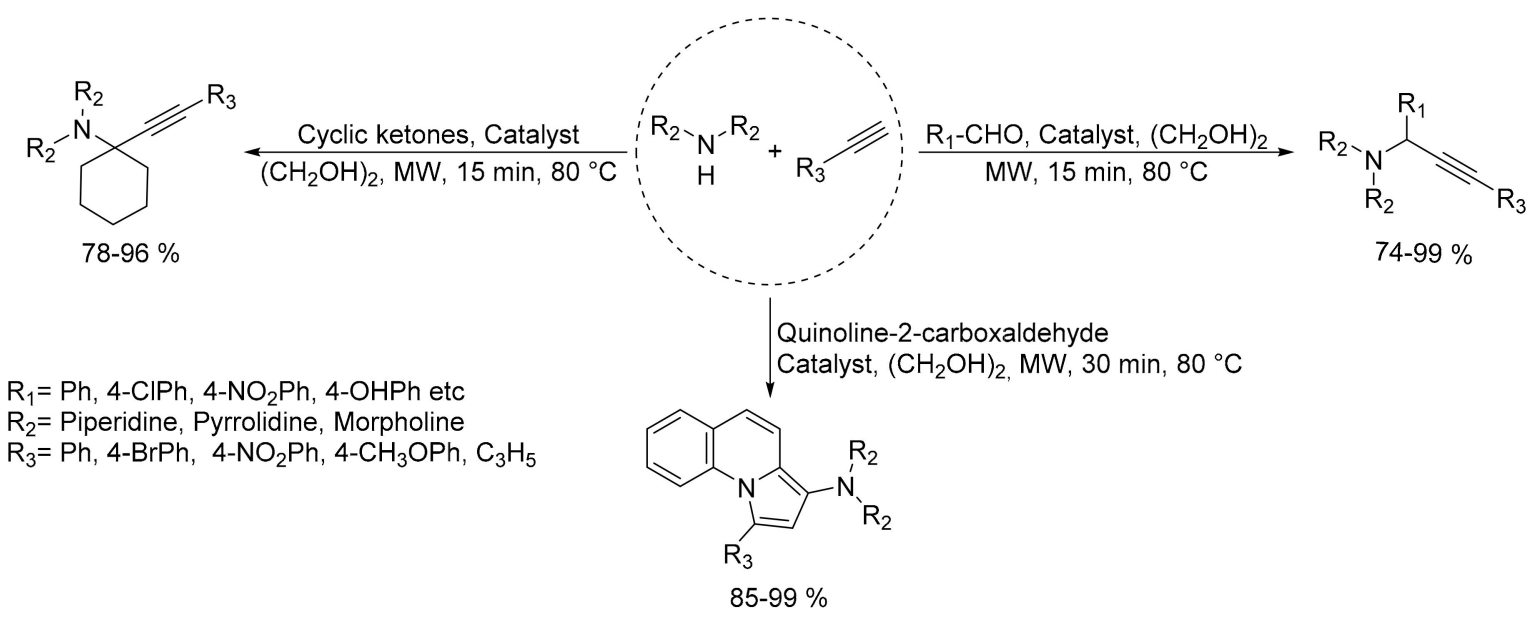

Scheme 33. CuNPs@ZnO-PTh catalyzed the synthesis of propargylamines under microwave reactor.

Under controlled microwave irradiation, Kashid and Balakrishna have described an efficient three component coupling reaction of an alkyne, an aldehyde and an amine $\left(\mathrm{A}^{3}\right)$ to produce propargylamine derivatives [59]. The reaction proceed smoothly using very low catalytic amount $(0.1 \mathrm{~mol} \%)$ of the copper based complex in acetonitrile as solvent $\left(\mathrm{CH}_{3} \mathrm{CN}\right)$, the reaction mixture was then heated in a microwave oven at $85^{\circ} \mathrm{C}$ for short reaction time $(5 \mathrm{~min})$ to generate the propargylamine derivatives in good to excellent yields, Scheme 34 . 


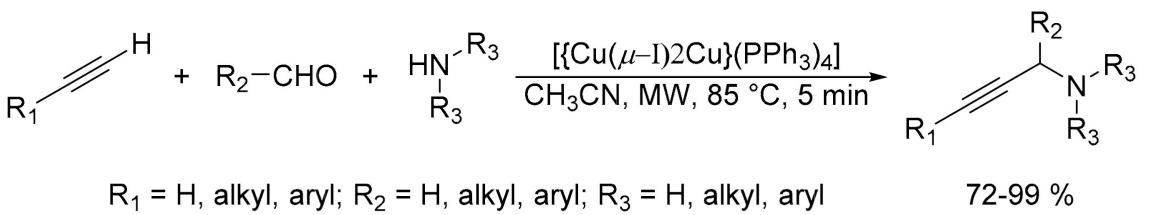

Scheme 34. Copper catalyzed microwave-assisted synthesis of propargylamines.

In another study utilizing microwave technology, polystyrene resin supported copper nanoparticles ( $\mathrm{Cu}$ NPs@Resin) have been developed by Kaur and coworkers for the synthesis of propargylamine derivatives via $\mathrm{A}^{3}$ coupling reaction of aldehyde, alkynes, and amines [60]. Cu NPs@Resin was used to catalyze the reaction in toluene as solvent. The reaction mixture was then heated at $100{ }^{\circ} \mathrm{C}$ in a microwave oven for $25 \mathrm{~min}$ to produce the desired products in moderate to excellent yields, Scheme 35.

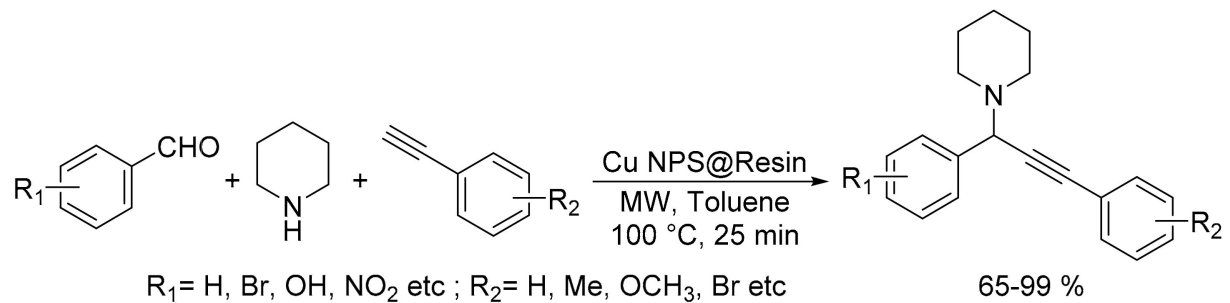

Scheme 35. Cu NPS@Resin catalyzed microwave-assisted synthesis of propargylamines.

$\mathrm{Xu}$ and coworkers have developed novel strategy of the three-component coupling among divers amino alcohols, aldehydes and alkynes using copper(I) chloride $(\mathrm{CuCl})$ as catalyst under microwave irradiation condition [61]. The reaction has proceeded smoothly to provide the desired propargylamines in low to excellent yields, Scheme 36.

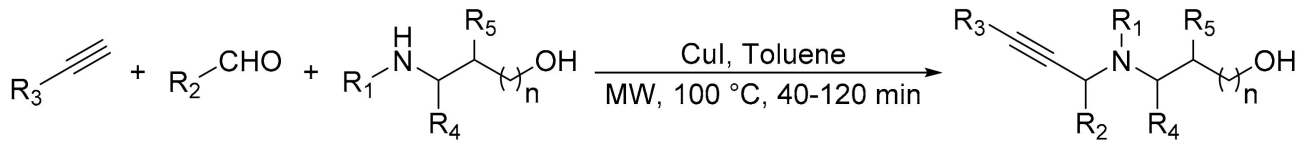

$\mathrm{R}_{1}=$ Benzyl, $\mathrm{Me}, \mathrm{Ph}$ etc $; \mathrm{R}_{2}=4-\mathrm{PhF}, 4-\mathrm{PhCl}, 4-\mathrm{PhMe}, 4-\mathrm{PhNO}_{2}$ etc

$\mathrm{R}_{3}=4-\mathrm{PhCN}, 4-\mathrm{PhF}, 4-\mathrm{PhOMe}, \mathrm{H}$ etc; $\mathrm{R}_{4}=\mathrm{Me}, 2 \mathrm{Me}$, Benzyl, $\mathrm{Ph}$, etc

$9-94 \%$

$\mathrm{R}_{5}=\mathrm{H}, \mathrm{Me}$ etc

Scheme 36. $\mathrm{CuCl}$ catalyzed microwave-assisted three-component reactions of alkynes, aldehydes, and amino alcohols.

Van der Eycken and coworkers have systematically examined several copper salt catalysts in different catalytic amount for the synthesis of secondary alkylpropargylamines via $\mathrm{A}^{3}$ coupling reaction with primary aliphatic amines under microwave conditions [62]. The most effective reaction conditions were achieved using a catalytic amount (20 mol \%) of copper $(\mathrm{I})$ bromide $(\mathrm{CuBr})$ in toluene as solvent, the reaction mixture was then heated in a microwave oven at $100{ }^{\circ} \mathrm{C}$ for $25 \mathrm{~min}$ to produce propargylamine derivatives in moderate to excellent yield, Scheme 37.

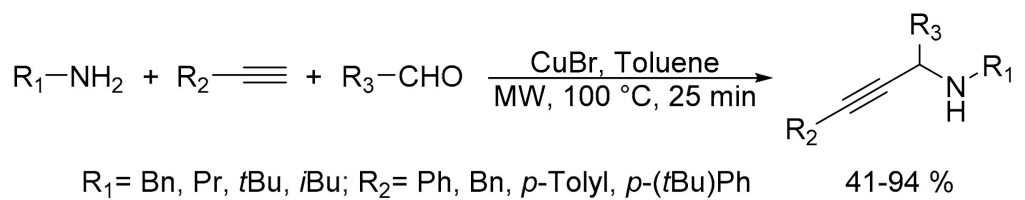

$\mathrm{R}_{3}=i \mathrm{Pr}, \mathrm{Et}, i \mathrm{Bu}, \mathrm{Pentyl}, \mathrm{Ph}, p-\mathrm{FPh}, \mathrm{C}-\mathrm{Pr}, \mathrm{C}-\mathrm{Hex}$

Scheme 37. $\mathrm{CuBr}$ catalyzed microwave-assisted $\mathrm{A}^{3}$ coupling for the synthesis of propargylamines.

A decarboxylative $\mathrm{A}^{3}$ coupling reaction of an alkynylcarboxylic acid with a secondary amine and an aldehyde forming tertiary propargylamines in high yields has been de- 
scribed [63]. The reaction was optimized include the use of catalytic amount (20 mol \%) of copper(I) iodide (CuI) for the decarboxylative cross-coupling reaction in toluene as solvent, the reaction mixture was then heated in microwave oven at $100{ }^{\circ} \mathrm{C}$ for $15 \mathrm{~min}$ to produce propargylamine derivatives in low to excellent yield, Scheme 38.

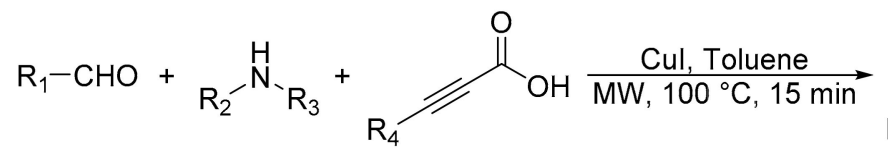

$R_{1}, R_{2}, R_{3}, R_{4}$ divers substituents, see reference cited<smiles>[R]C#CC([R])N([R])[R]</smiles>

$25-96 \%$

Scheme 38. CuI catalyzed microwave-assisted decarboxylative $\mathrm{A}^{3}$ cross coupling reaction.

In a similar study same author have reported on the synthesis of propargylamine based 1,4-diamino-2-butynes via one pot $\mathrm{Cu}(\mathrm{I})$-catalyzed $\mathrm{A}^{3}$ decarboxylative coupling of a propiolic acid, an aldehyde, and substituted amines [64]. Moreover, polysubstituted propargylamines have been synthesized using decarboxylative three-component coupling of a 2-oxoacetic acid, substituted amine and an alkyne [65]. On the other hand, Tong and coworkers have reported the synergistic effect of dual copper catalysts to catalyzed $\mathrm{A}^{3}$ cross coupling/decarboxylative domino reactions [66]. While Organ and coworkers have reported on the preparation of propargylamines using microwave-assisted continuous-flow organic synthesis (MACOS) technology for the reaction among aldehydes or ketone with amines and terminal alkynes [67].

Scheme 39 summarizes the proposed catalytic cycle for the preparation of propargylamine derivatives. The mechanism starts from the condensation of an amine with an aldehyde leading to the formation of imine (Schiff base), followed by coordination of alkyne and $\mathrm{Cu}(\mathrm{I})$ to generate an alkenyl-copper complex along with the imine designated intermediate (I). Intermediate (II) is resulted from nucleophilic alkyne attack on activated imine carbon to generate a new $\mathrm{C}-\mathrm{C}$ bond leading finally to form the highly substituted propargylamines (III) by decomplexation step and regeneration of the active species of the catalyst [59].

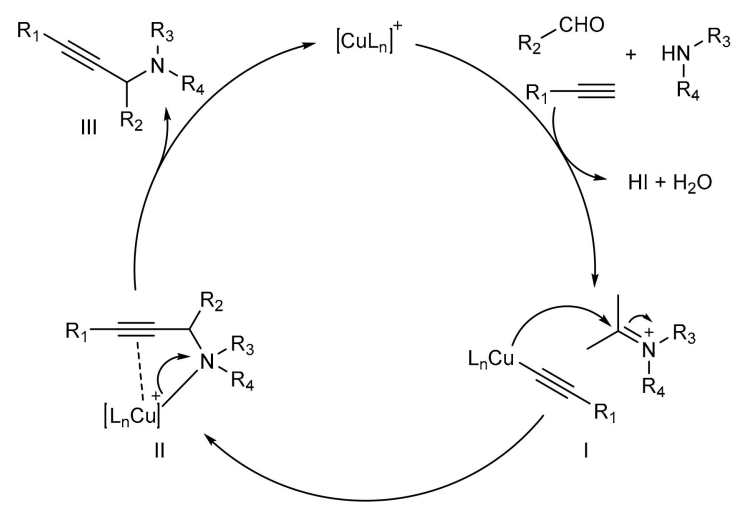

Scheme 39. A proposed mechanism for copper-catalyzed microwave-assisted synthesis of propargylamines.

\subsection{Synthesis of Heterocyclic Systems}

Heterocyclic compounds are cyclic aliphatic or aromatic organic molecules that at least one of the carbons in the ring being replaced with a heteroatom-such as $\mathrm{N}, \mathrm{O}, \mathrm{S}$, $\mathrm{P}$, etc. A heterocyclic ring system has been reported to be part of many natural product compounds, pharmaceuticals, and biologically active compounds. Therefore, and due to its important applications, several organic synthetic methodologies have been developed for the synthesis of this important class of molecules, among these recently developed methodologies is the use of copper under microwave irradiation technology. 
Sayyad, N. et al. have reported on a dimerization reaction of two molecules of orthohallobenzamides furnishing new quinazolinone derivatives via intramolecular cyclization reaction using copper iodide under microwave irradiation [68]. The hallobenzamides were treated in different alcohol—namely methanol, ethanol, or propanol-as solvent in the presence of copper(I) iodide (CuI) as catalyst and cesium carbonate $\left(\mathrm{Cs}_{2} \mathrm{CO}_{3}\right)$ as base, the resulting mixture was then heated in a microwave oven at $120^{\circ} \mathrm{C}$ for $10 \mathrm{~min}$ to produce quinazolinones in low to very good yield, Scheme 40 . The reaction proceeds via two intermediates pathway in which the solvent used in the reaction (methanol, ethanol, and propanol) acts as a nucleophile generating alkoxy substitution.

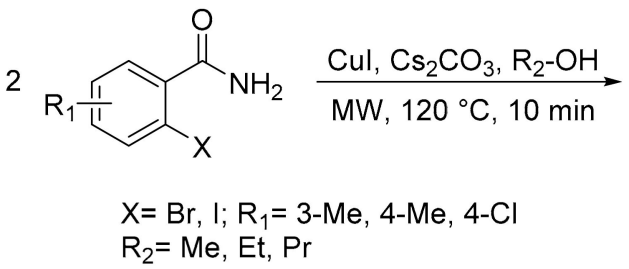<smiles>[R]Oc1cc[R1]([R])cc1-c1nc2ccc([R])cc2c(=O)[nH]1</smiles>

Scheme 40. CuI catalyzed microwave-assisted dimerization of ortho-hallobenzamides.

Under controlled microwave processes, Cho and coworkers have developed a new synthetic method for the synthesis of novel azole-fused pyrimidinones starting from $\beta$-bromo- $\alpha, \beta$-unsaturated amides and different azoles, e.g., imidazole, pyrazole, and benzimidazole [69]. The reaction proceeds via intermolecular $\mathrm{C}-\mathrm{N}$ bond formation. Elemental copper $(\mathrm{Cu})$ powder was used under microwave irradiation in the presence of $\mathrm{K}_{2} \mathrm{CO}_{3}$ as base and DMF as solvent, the resulting mixture was then heated in a microwave oven at $100{ }^{\circ} \mathrm{C}$ for $1 \mathrm{~h}$ yielding the desired product in low to very good yield, Scheme 41 .

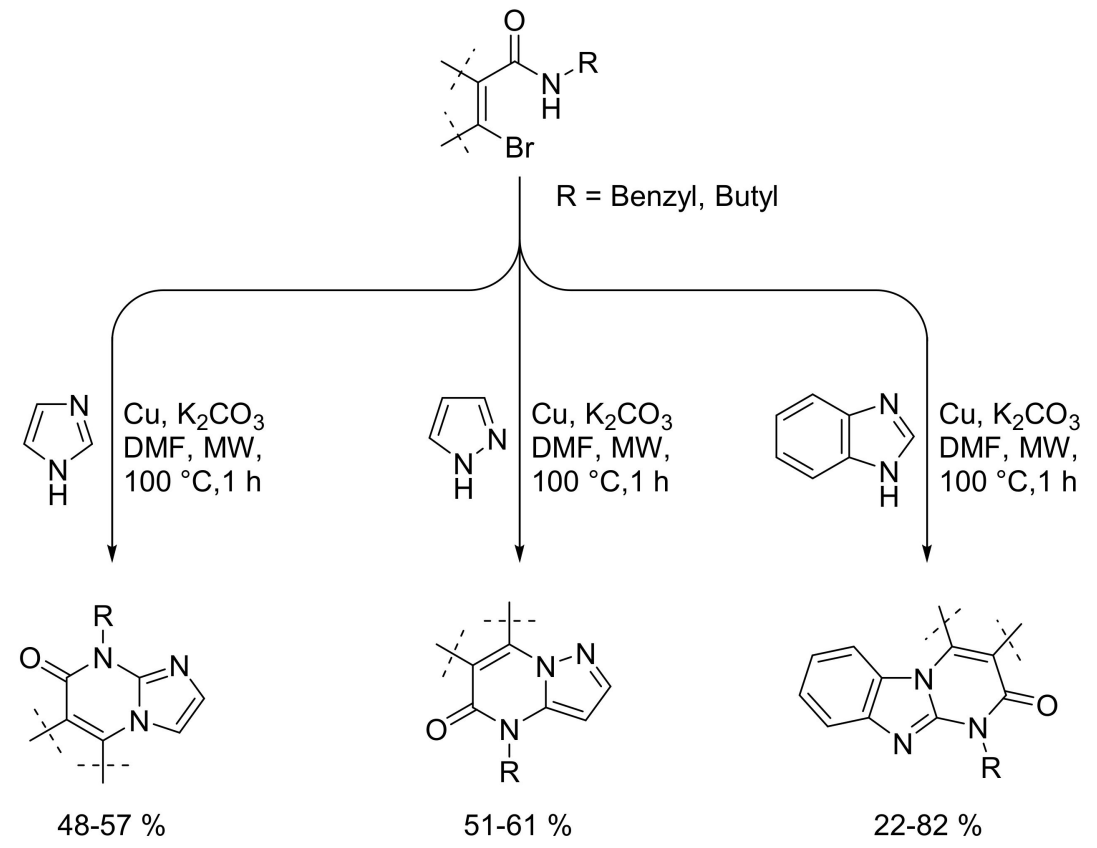

Scheme 41. Cu catalyzed microwave-assisted synthesis of azole-fused pyrimidinones.

A microwave-assisted cross-coupling reaction using copper(I) iodide (CuI) was proposed by Jacob and coworkers as an efficient method to access fused 1,2,3-triazolo-1,3,6triazonine derivatives [70]. The authors have reported on the reaction between 5-iodo-1,2,3triazoyl benzaldehyde derivatives and substituted ortho-diaminobenzenes in the presence of catalytic amount ( $5 \mathrm{~mol} \%$ ) of $\mathrm{CuI}$ in DMSO as solvent, the reaction mixture was then 
heated in a microwave oven at $100{ }^{\circ} \mathrm{C}$ for $1 \mathrm{~h}$ and the desired novel heterocycles were obtained in moderate to excellent yields, Scheme 42.<smiles>[R]c1nnn(-c2ccc(C(C)(C)C)cc2)c1I</smiles>

$\mathrm{R}_{1}=\mathrm{H}, 4,5-d i-\mathrm{Me} ; \mathrm{R}_{2}=\mathrm{H}, 4-\mathrm{Cl}$

$\mathrm{R}_{3}=\mathrm{H}, 4-\mathrm{Me}, 4-\mathrm{F}$, cyclopropyl, phenyl<smiles>[R]c1ccc2c(cnc3ccc([R])cc3[nH]c3c([R])nnn32)c1</smiles>

$37-86 \%$

Scheme 42. CuI catalyzed microwave-assisted synthesis of fused 1,2,3-triazolo-1,3,6-triazonines.

$\mathrm{Li}$, Z. et al. have proposed the synthesis of $4 \mathrm{H}$-benzo[f]imidazo[1,4]diazepin-6-ones by post-Ugi copper-catalyzed intramolecular coupling reaction [71]. The desired products were obtain in moderate to high yield using copper-I iodide (CuI) via cycloaddition reaction of four components under microwave irradiation, the reaction proceed smoothly using $\mathrm{Cs}_{2} \mathrm{CO}_{3}$ as base in DMSO as solvent, the resulting mixture was then heated in a microwave oven at $100{ }^{\circ} \mathrm{C}$ for $30 \mathrm{~min}$ to produce $4 \mathrm{H}$-benzo[f $]$ imidazo[1,4]diazepin-6-ones in low to very good yields, Scheme 43 .<smiles>O=Cc1c[nH]cn1</smiles><smiles>[R]N</smiles>

1. $\mathrm{MeOH}, \mathrm{rt}$ $\underset{\mathrm{MW}, 100{ }^{\circ} \mathrm{C}, 30 \mathrm{~min}}{\stackrel{\text { 2ul, } \mathrm{Cs}_{2} \mathrm{CO}_{3} \text {, DMSO }}{\longrightarrow}}$ $\mathrm{R}_{3}-\mathrm{CN}$<smiles>O=C(O)c1cc[nH+]cc1I</smiles><smiles></smiles>

$34-86 \%$

$$
\begin{aligned}
& \mathrm{X}=\mathrm{CH}, \mathrm{N} ; \mathrm{Y}=\mathrm{CH}, \mathrm{N} \\
& \mathrm{R}_{1}=\text { benzyl, 4-MeO-benzyl, 3,4-di-OMe-benzyl } \\
& \mathrm{R}_{2}=\mathrm{H}, \mathrm{F}, \mathrm{Cl} ; \mathrm{R}_{3}=n \text {-butyl, } t \text {-butyl, cyclohexyl }
\end{aligned}
$$

Scheme 43. CuI catalyzed microwave synthesis of $4 H$-benzo[f $]$ imidazo[1,4]diazepin-6-ones.

In another study, Rout, L. et al. have developed new $\mathrm{Cu} @ \mathrm{Ag}$ core-shell nanoparticles (Cu@Ag NPs) and they have explored their application to catalyze the synthesis of octahydroquinazolinone derivatives [72]. The newly developed nanoparticles (Cu@Ag NPs) have been used for the synthesis of the target compounds via one-pot condensation reaction of three components; aromatic aldehydes, cyclic-diketones, and urea in solvent free condition to obtain octahydroquinazolinone in moderate to excellent yield in short reaction time (1-5 min), Scheme 44.

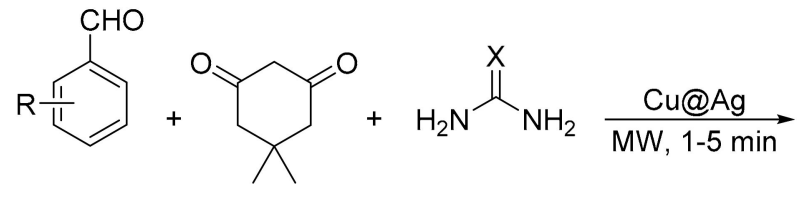

$X=O, S$

$$
X=0, s
$$

$\mathrm{R}=\mathrm{H}, 2-\mathrm{Cl}, 4-\mathrm{Cl}, 4-\mathrm{Me}, 2-\mathrm{OH}, 4-\mathrm{OH}, 2-\mathrm{OMe}, 4-\mathrm{OMe}, 2-\mathrm{NO}_{2}, 3-\mathrm{NO}_{2}$

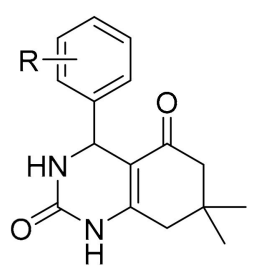

$55-96 \%$

Scheme 44. Cu@Ag NPs catalyzed microwave-assisted synthesis of octahydroquinazolinone compounds. 
Under controlled microwave-assisted copper-catalyzed reaction condition, Ke and coworkers have developed new strategy for the synthesis of quinazolinone derivatives in aqueous media [73]. They have systematically improved the reaction utilizing different copper oxidation states, such as $\mathrm{CuI}, \mathrm{CuCl}_{2}, \mathrm{CuO}, \mathrm{CuSO}_{4}$, and $\mathrm{Cu}(\mathrm{OAc})_{2}$. The optimized reaction conditions suggests that a catalytic amount (10 $\mathrm{mol} \%$ ) of $\mathrm{CuCl}_{2}$ and $10 \mathrm{~mol} \%$ of 8-hydroxyquinoline as ligand in water as solvent is the most effective combination to access the target compounds. The reaction mixture was then stirred at room temperature for $20 \mathrm{~min}$ under microwave irradiation with cooling to maintain the reaction at room temperature, furnishing quinazolinone derivatives in moderate to excellent yields, Scheme 45 .

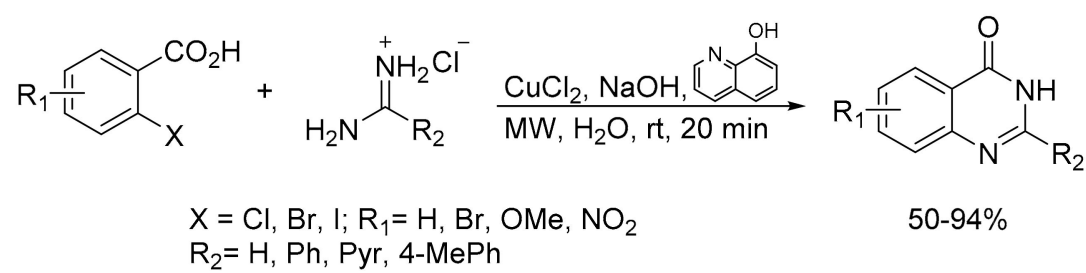

Scheme 45. Copper-catalyzed microwave assisted synthesis of quinazolinone derivatives.

In a similar study for the synthesis of quinazoline derivatives, Kundu, L.M. et al. have reported on the use of copper(I) oxide $\left(\mathrm{Cu}_{2} \mathrm{O}\right)$ under microwave irradiation via $\mathrm{C}-\mathrm{N}$ bond formation followed by ring closure. The reaction proceeds smoothly starting from ortho-halo $(\mathrm{Cl}$ or $\mathrm{Br})$ aromatic carboxylic acids with guanidine hydrochloride in ligand free conditions [74]. The mixture of starting materials, catalytic amount $(10 \mathrm{~mol} \%)$ of $\mathrm{Cu}_{2} \mathrm{O}$, and $\mathrm{Cs}_{2} \mathrm{CO}_{3}$ as base in DMF as solvent was heated in a microwave oven at $120{ }^{\circ} \mathrm{C}$ for $20 \mathrm{~min}$ to produce the quinazoline derivatives in moderate to very good yields, Scheme 46.

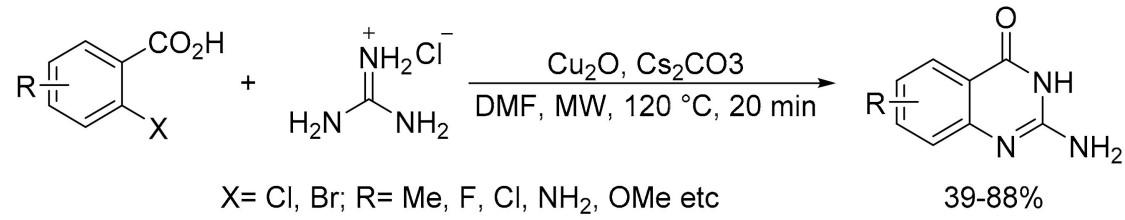

Scheme 46. $\mathrm{Cu}_{2} \mathrm{O}$ catalyzed microwave-assisted synthesis of quinazoline derivatives.

On the other hand, Bhanage and coworkers have developed new copper(I) oxide nanocubes $\left(\mathrm{Cu}_{2} \mathrm{O}\right.$-nanocubes $)$ and utilized it for the synthesis of quinazoline derivatives starting from 2-bromobenzaldehydes and amidine hydrochloride derivatives [75]. The reactants were treated with catalytic amount $\left(5 \mathrm{~mol} \%\right.$ ) of $\mathrm{Cu}_{2} \mathrm{O}$-nanocubes, $\mathrm{Cs}_{2} \mathrm{CO}_{3}$ as base and ethylene glycol $\left(\left(\mathrm{CH}_{2} \mathrm{OH}\right)_{2}\right)$, the reaction mixture was then irradiated at 360 Watt in a microwave oven for $2 \mathrm{~min}$ furnishing 2-phenylquinazoline derivatives in moderate to excellent yields, Scheme 47.

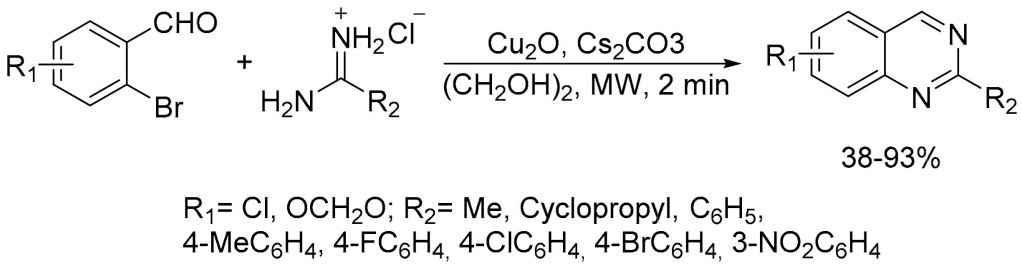

Scheme 47. $\mathrm{Cu}_{2} \mathrm{O}$-nanocubes catalyzed microwave-assisted synthesis of quinazoline derivatives.

$\mathrm{Xu}$ and coworkers have reported on the syntheses of 1,4-oxathiines and 1,4-dioxines under microwave irradiation [76,77]. The reaction proceed via ring expansion of thiiranes and oxiranes with $\alpha$-diazo- $\beta$-dicarbonyl moieties. They have examined two types of copper 
catalysts, namely $\mathrm{CuSO}_{4} \cdot 5 \mathrm{H}_{2} \mathrm{O}$ and $\mathrm{Cu}(\mathrm{hfacac})_{2} \cdot \mathrm{xH}_{2} \mathrm{O}$ in dichloroethane (DCE) as solvent and microwave heating at $100-150{ }^{\circ} \mathrm{C}$ for $20 \mathrm{~min}$, Scheme 48 .

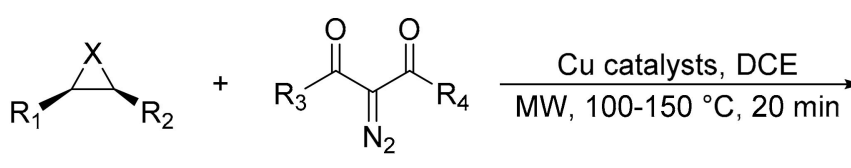

$\mathrm{X}=\mathrm{O}, \mathrm{S}$

$\mathrm{R}_{1}=\mathrm{R}_{2}=$ cyclic butane, cyclic propane; $\mathrm{R}_{2}=\mathrm{H}$, butyl, hexyl $\mathrm{R}_{3}=\mathrm{H}, \mathrm{Ph}, \mathrm{OEt}, \mathrm{CF}_{3} ; \mathrm{R}_{4}=\mathrm{CO}_{2} \mathrm{Me}, \mathrm{CO}_{2} \mathrm{Et}, \mathrm{COMe}$<smiles>[R]C(=O)C1=C([R])OC([R])C([R2])[X]1</smiles>

$\mathrm{X}=\mathrm{S}$, trans-products trace $-56 \%$ $\mathrm{X}=\mathrm{O}$, cis-products $10-45 \%$

Scheme 48. Copper catalyzed microwave-assisted synthesis of 1,4-oxathiines and 1,4-dioxines.

In spite of the fact that this reaction produces the desired compounds in only low to moderate yields, but it is considered as one of the most important method described to access such biologically important heterocyclic compounds.

A new series of benzodifuran-based bis( $N$-(het)arylthiazol-2-amine) derivatives have been developed as antibacterial agents. These compounds were synthesized starting from $\mathrm{O}, \mathrm{O}$-diacetyl dioxime and aryl-isothiocyanates under microwave irradiation. The reaction produced higher yield within short reaction time compared to conventional heating [78]. A catalytic amount $\left(20 \mathrm{~mol} \%\right.$ ) of $\mathrm{CuI}$, in the presence of $\mathrm{Cs}_{2} \mathrm{CO}_{3}$ as a base and dioxane as solvent, the resulting mixture was then heated in a microwave oven at $100{ }^{\circ} \mathrm{C}$ for $15-25 \mathrm{~min}$ to produce benzodifuran-based bis( $N$-(het)arylthiazol-2-amine) derivatives in high yields, Scheme 49.

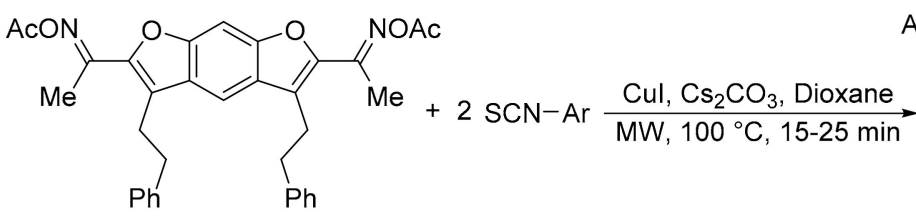

$\mathrm{Ar}=\mathrm{C}_{6} \mathrm{H}_{5}, 2-\mathrm{FC}_{6} \mathrm{H}_{4}, 4-\mathrm{FC}_{6} \mathrm{H}_{4}, 2-\mathrm{BrC}_{6} \mathrm{H}_{4}$

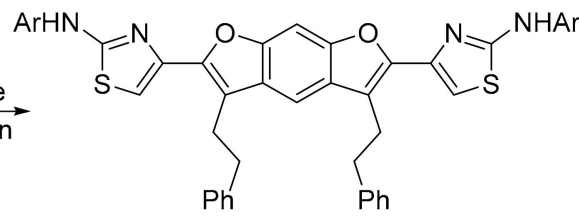

$82-90 \%$

Scheme 49. CuI catalyzed microwave-assisted synthesis of benzodifuran-based bis( $N$-(het)arylthiazol-2-amine) compounds.

A silver/copper cocatalyst has been developed by Wang and coworkers for the synthesis of substituted carbazoles via cascade intramolecular cyclization/desulfinamide/ dehydrogenation in one pot reaction under microwave irradiation [79]. The author has optimized the reaction condition to the use of catalytic amounts of the both cocatalysts, $20 \mathrm{~mol} \%$ of copper(II) acetate $\left(\mathrm{Cu}(\mathrm{OAc})_{2}\right)$ and $10 \mathrm{~mol} \%$ of silver hexafluoroantimonate $\left(\mathrm{AgSbF}_{6}\right)$ in the presence of chloranil as oxidizing agent in dichloroethane (DCE) as solvent, the reaction mixture was then heated in a microwave oven at $80^{\circ} \mathrm{C}$ for $2.5 \mathrm{~h}$ furnishing substituted carbazoles in moderate to very good yields, Scheme 50.

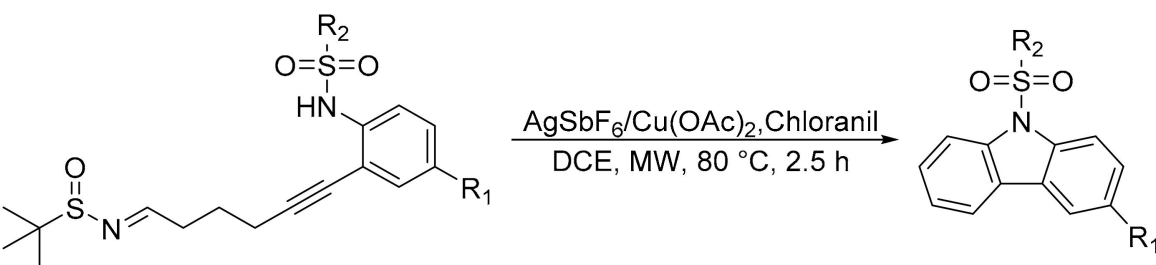

$\mathrm{R}_{1}=\mathrm{H}, \mathrm{F}, \mathrm{Cl}, \mathrm{Br}$, Me etc

$\mathrm{R}_{2}=\mathrm{C}_{6} \mathrm{H}_{5}, 4-\mathrm{FC}_{6} \mathrm{H}_{4}, 4-\mathrm{ClC}_{6} \mathrm{H}_{4}, 4-\mathrm{BrC}_{6} \mathrm{H}_{4}$ etc
$60-83 \%$

Scheme 50. Silver/copper cocatalyzed microwave-assisted synthesis of substituted carbazoles.

Under controlled microwave irradiation condition, Cho and coworkers have prepared indolo[2,1-a]isoquinolines using copper(I) iodide to catalyze the intermolecular cyclization of 2-(2-bromoaryl)-1H-indoles with 1,3-diketones [80]. The reaction proceed smoothly 
using a very low catalytic amount $(0.03 \mathrm{~mol} \%)$ of copper(I) iodide $(\mathrm{CuI})$ and potassium phosphate $\left(\mathrm{K}_{3} \mathrm{PO}_{4}\right)$ as base in $N, N$-dimethylformamide (DMF) as solvent, the reaction mixture was heated in a microwave oven at $130{ }^{\circ} \mathrm{C}$ for $1 \mathrm{~h}$ to produce the corresponding indolo[2,1-a]isoquinoline derivatives in low to good isolated yields, Scheme 51.

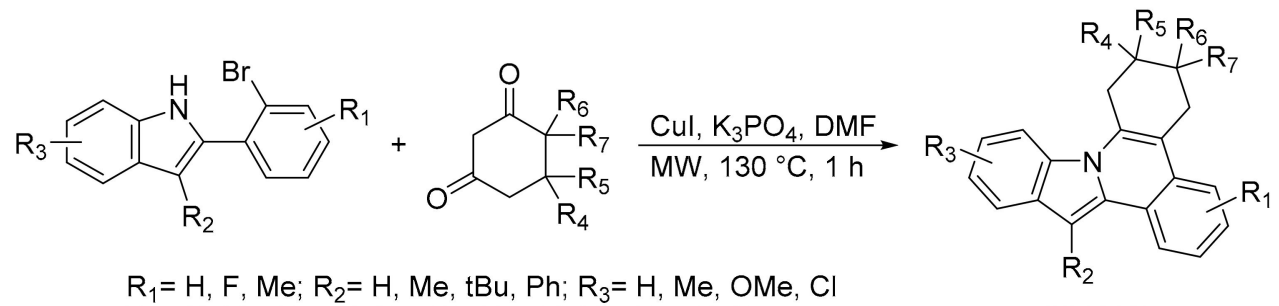$$
\mathrm{R}_{4}=\mathrm{H}, \mathrm{Me} ; \mathrm{R}_{5}=\mathrm{H}, \mathrm{Me}, \mathrm{Ph} ; \mathrm{R}_{6}=\mathrm{H}, \mathrm{Me} ; \mathrm{R}_{7}=\mathrm{H}, \mathrm{Me}
$$

$26-77 \%$

Scheme 51. CuI catalyzed microwave-assisted synthesis of indolo[2,1-a]isoquinolines.

Padmaja, R.D. et al. have developed novel catalyst, $\left[\mathrm{Cu}(\mathrm{phen})\left(\mathrm{PPh}_{3}\right)_{2}\right] \mathrm{NO}_{3}$, to catalyze the synthesis of 5-substituted $1 \mathrm{H}$-tetrazoles under microwave conditions [81]. The reaction proceed via cycloaddition reaction of various substituted nitriles with sodium azide $\left(\mathrm{NaN}_{3}\right)$ in equal volume (1:1) of water and isopropanol $\left(\mathrm{H}_{2} \mathrm{O}: \mathrm{IPA}\right)$ as solvent, the resulting mixture was then heated in a microwave oven at $65^{\circ} \mathrm{C}$ for $15 \mathrm{~min}$ to produce the target compounds in good to excellent yields, Scheme 52.

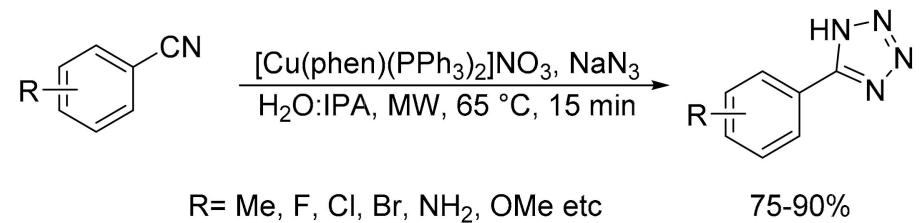

Scheme 52. $\left[\mathrm{Cu}(\mathrm{phen})\left(\mathrm{PPh}_{3}\right)_{2}\right] \mathrm{NO}_{3}$ catalyzed microwave-assisted synthesis of 5-substituted $1 H$-tetrazoles.

Copper or its salts as catalyst under microwave irradiation has been extensively studied for the construction of heterocyclic systems. For examples, 3,5-disubstituted isoxazoles from the natural maslinic and oleanolic acids [82], 1,2-disubstituted indoles from $\alpha$-aminonitriles and 2-halobenzyl halides [83], 3,3-disubstituted oxindoles from oxidative cyclization of acrylamide derivatives with non-activated ketones [84], substituted pyrroles via tandem copper-catalyzed propargylation/alkyne azacyclization/isomerization reaction [85], aziridines through Kinugasa conditions [86], fused imidazo heterocycles via multi-component reaction [87], 5-alkylamino- $1 \mathrm{H}$-pyrazole-4-carbaldehydes [88], 3,4diaryl isoquinolines using $\mathrm{N}$-tert-butyl-o-iodobenzaldimine, phenylacetylene and iodobenzene as starting materials [89], pyrimidinones from the coupling and cyclization of $\beta$ bromo- $\alpha, \beta$-unsaturated amides with amidine hydrochlorides $[90,91]$, pyrimidinones using three component Biginelli reaction [92], 3- $N$-sulfonylamidine coumarins via four component coupling reaction [93], $2 \mathrm{H}$-pyran-2-ones from the cycloaddition of $\beta$-bromo- $\alpha, \beta$ unsaturated carboxylic acids with 1,3-diketones [94], furoquinoxalines from 2-amino substituted anilines, ethyl glyoxalate, and terminal alkynes through tandem $\mathrm{A}^{3}$ coupling followed by a 5-endo-dig cyclization process [95], 5,6-dihydroindolo[1,2-a]quinoxaline derivatives via intramolecular $N$-arylation [96], isoquinolines and pyridines under multicomponent reaction of $\beta$-halovinyl/aryl aldehyde, aromatic/aliphatic terminal alkyne and tert-butylamine/benzamidine [97] and from $o$-bromoarylaldehydes, terminal alkynes, and aqueous ammonia [98], 2-aminooxazolo [4,5-b] pyridines through intramolecular C-O bond formation in aqueous medium [99], chiral nopinane-annelated pyridines from the reaction of pinocarvone oxime with enamines [100], dihydropyridines from substituted aromatic aldehydes using Hantzsch synthesis [101], pyrazole-based heterocycles via domino annulation [102], 2,6-diaminopyridines through amination of halopyridines [103], pyrazoles via $N$-arylation [104], phenylethynyl[1,2,4]methyltriazines from the cross coupling of 
5-methyl-3-methyl-thio[1,2,4]triazine with various phenylacetylenes [105], pyrazolo[3,4b]indoles and new isoxazolo[5,4-b]indoles [106], indole-2-carboxylic acid esters in ionic liquid from the condensation of 2-halo-aryl aldehydes or ketones and ethyl isocyanoacetate using ionic liquid [107], 6,9-disubstituted purin-8-ones [108], 3-benzazepines using three-component coupling of an aldehyde, an alkyne and an amine ( $\mathrm{A}^{3}$ coupling) forming propargylamines intermediate leading to 3-benzazepines [109], dibenzoazocines and dibenzoazepines via intramolecular $\mathrm{A}^{3}$ coupling reaction [110], and the rapid synthesis of 3,4-fused chromenopyridinones [111].

\subsection{Carbon-Hydrogen (C-H) Bond Functionalization}

The ability to selectively generate new aryl-carbon $(\mathrm{Ar}-\mathrm{C})$ bond is one of the longstanding challenges for the organic chemist community. One of these strategies is to activate the non-reactive $\mathrm{C}-\mathrm{H}$ bond by applying novel catalyst that work in a regioselective manner.

Under microwave-assisted synthesis $\mathrm{C}-\mathrm{H}$ bond arylation have been reported using copper catalysts for the synthesis of substituted pivanilides by Yang, H.J. et al. [112]. The authors have found that pivanilides selectively direct the arylation reaction towards the metaposition by using homogeneous or heterogeneous copper based catalyst, $\mathrm{Cu}(\mathrm{OTf})_{2} / \mathrm{DTBP}$ and $\mathrm{Cu}-\beta$ zeolite/DTBP respectively, the reaction proceed in dichloroethane (DCE) as solvent, the reaction mixture was then irradiated in a microwave oven at $80^{\circ} \mathrm{C}$ for $30-60 \mathrm{~min}$ to produce pivanilide derivatives in moderate to excellent yields, Scheme 53.

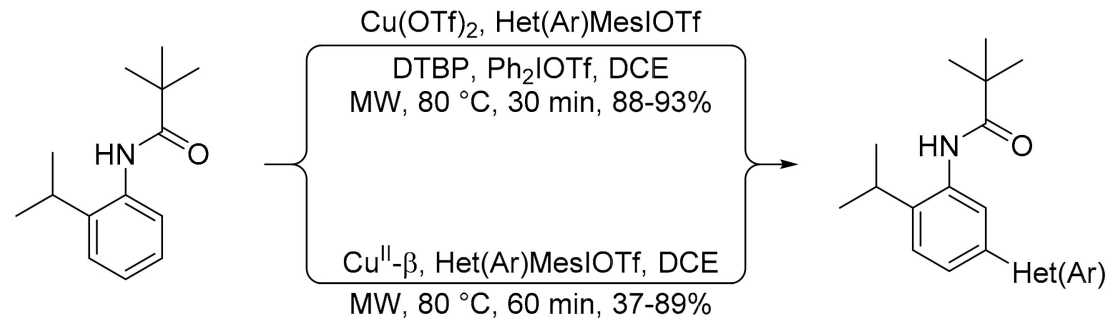

Scheme 53. Homogeneous and heterogeneous copper catalyzed microwave-assisted synthesis of pivanilides.

Besson and coworkers have developed thiazolo[5,4-f]quinazolin-9(8H)-one in two step $\mathrm{C}-\mathrm{H}$ activation under microwave irradiation [113]. Regioselective $\mathrm{C}-2$ and $\mathrm{C}-7$ arylation of thiazolo[5,4-f] quinazolin-9(8H)-one has been achieved using cocatalysts between copper and palladium, in the presence of base (DBU and $\mathrm{LiOtBu})$. The resulting mixture was then heated in a microwave oven at $120^{\circ} \mathrm{C}$ for relatively long reaction time $(5 \mathrm{~h})$ to introduce divers aryl moieties at position C-2 and C-7 of the thiazolo[5,4-f] quinazolin-9(8H)-one core in moderate to high yields, Scheme 54 .

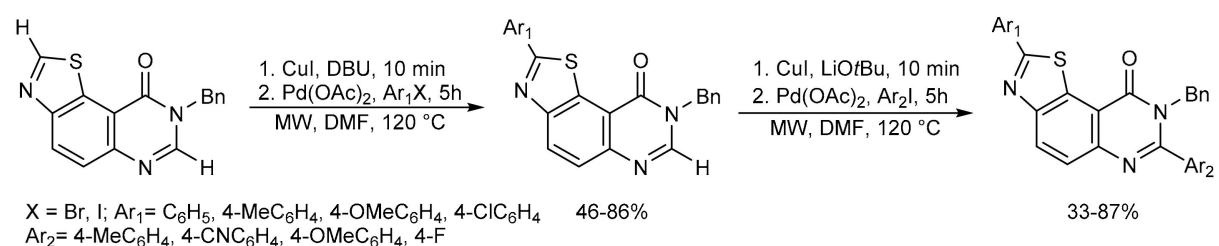

Scheme 54. CuI catalyzed microwave-assisted arylation of thiazolo[5,4-f]quinazolin-9(8H)-one.

In another study, by same authors, a direct arylation of quinazolin-4-one under microwave-assisted process has been described [114]. The arylation reaction proceed via cocatalysts using mixture of copper(I) iodide (CuI) and palladium(II) acetate $\left(\mathrm{Pd}(\mathrm{OAc})_{2}\right)$ in the presence of lithium tert-butoxide $(\mathrm{LiO} t \mathrm{Bu})$ as base in DMF as solvent. The reaction mixture was then heated in a microwave oven at $120^{\circ} \mathrm{C}$ for $30 \mathrm{~min}$ to produce $\mathrm{C}-2$ substituted (2H)-quinazolin-4-ones in low to excellent yields, Scheme 55. 


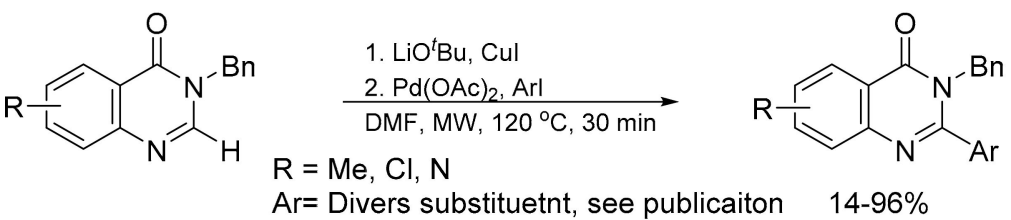

Scheme 55. $\mathrm{Cu} / \mathrm{Pd}$ catalyzed microwave-assisted $\mathrm{C}-\mathrm{H}$ arylation of quinazolin-4-ones with aryl iodides.

Under controlled microwave heating condition, Yuan, J. et al. have carried out $\mathrm{C}-\mathrm{H}$ amidation of quinoxalin-2(1H)-ones using copper catalyst [115]. The reaction proceed with catalytic amount $\left(4 \mathrm{~mol} \%\right.$ ) of copper(I) bromide $(\mathrm{CuBr})$ in the presence of $\mathrm{K}_{2} \mathrm{~S}_{2} \mathrm{O}_{8}$ as oxidizing agent in $\mathrm{CH}_{3} \mathrm{CN}$ as solvent, the reaction mixture was then heated in a microwave oven at $80^{\circ} \mathrm{C}$ for $30 \mathrm{~min}$. The authors found that this reaction being tolerated for divers functional groups, including (hetero)aryl amides (primary and secondary) and aliphatic amides (cyclic and acyclic) to produce amidated quinoxalin-2(1H)-ones in good to excellent yields, Scheme 56.

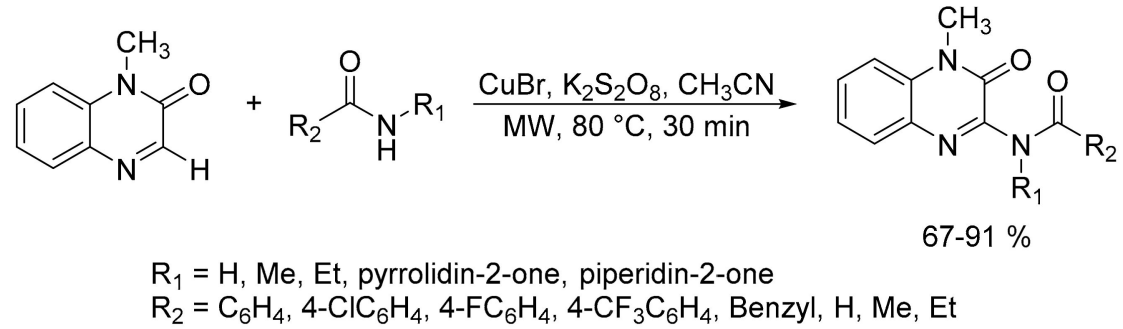

Scheme 56. CuBr catalyzed microwave-assisted amidation of quinoxalin-2(1H)-ones.

A microwave-assisted regioselective alkenylation at C-8 position in purines and azoles, such as caffeine, 1,3,4-oxadiazole, 5-phenyloxazole, $N$-methylbenzimidazole, benzothiazole, 1,2,4-triazole, and oxazole using microwave reactor has been described by Piguel and coworkers [116]. The reaction has been carried out using cocatalyst composed of copper(I) iodide $(\mathrm{CuI})$ and palladium(II) acetate $\left(\mathrm{Pd}(\mathrm{OAc})_{2}\right)$, in the presence of phenantroline as ligand, $\mathrm{LiO} t \mathrm{Bu}$ as base in dioxane as solvent, the resulting mixture was then heated in a microwave oven at $120^{\circ} \mathrm{C}$ for $30 \mathrm{~min}$ to produce the target compounds in low to very good yields, Scheme 57.

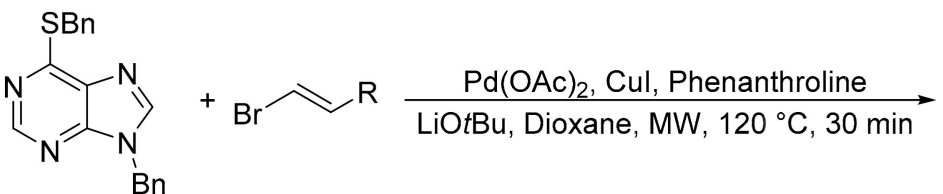

$\mathrm{R}=4-\mathrm{MePh}, 3-\mathrm{FPh}, 3-\mathrm{BrPh}, 4-\mathrm{CF}_{3} \mathrm{Ph}$<smiles>[R]C=Cc1nc2c(Br)ncnc2n1Cc1ccccc1</smiles>

$24-71 \%$

$$
\begin{aligned}
& \text { HeteroAryl }-\mathrm{H}+{ }_{\mathrm{Br}} \leadsto \mathrm{Ph} \frac{\mathrm{Pd}(\mathrm{OAc})_{2} \text {, Cul, Phenanthroline }}{\mathrm{LiOtBu} \text {, Dioxane, } \mathrm{MW}, 120^{\circ} \mathrm{C}, 30 \mathrm{~min}} \text { HeteroAryl }{ }_{\mathrm{Ph}} \\
& \text { HeteroAryl = caffeine, 1,3,4-oxadiazole, 5-phenyloxazole, } \\
& \mathrm{N} \text {-methylbenzimidazole, benzothiazole, 1,2,4-triazole and oxazole }
\end{aligned}
$$

Scheme 57. $\mathrm{CuI}$ and $\mathrm{Pd}(\mathrm{OAc})_{2}$ cocatalyzed microwave-assisted alkenylation at $\mathrm{C}-8$ position in purines and azoles.

\subsection{N-(Hetero)Arylation and N-Alkylation Reaction}

$N$-(Hetero)Aryl- and $N$-alkyl-substituted heterocycles are common pharmacophores in natural products and biologically active synthesized compounds. Therefore, scientists keep interest in the development of novel methodologies for $N$-(hetero)arylation and $N$ alkylation. Mild and efficient $N$-(hetero)arylation and $N$-alkylation of heterocycles has 
been developed with palladium and copper catalysts. Using palladium to catalyze $N$ (hetero)arylation and $\mathrm{N}$-alkylation are encountered with some limitations mainly due to the high cost of the catalyst. Therefore, copper-catalyzed reactions received significant attention for such kind of reactions [106,112].

Using microwave heating technique, Abe, T. et al. have reported on the arylation reaction of 2-azabicyclo[2.2.1] hept-5-en-3-ones with arylboronic acids with copper catalyst to produce the related $\mathrm{N}$-aryl compounds [117]. The reaction optimized to the use of a catalytic amount (10 mol \%) of copper(II) acetate $\left(\mathrm{Cu}(\mathrm{OAc})_{2}\right)$, in the presence of arylboronic acids and $\mathrm{KOH}$ as base in acetonitrile, the reaction mixture was then heated in a microwave oven at $80^{\circ} \mathrm{C}$ for $30-120$ min producing the title compounds in moderate to very good yield, Scheme 58.

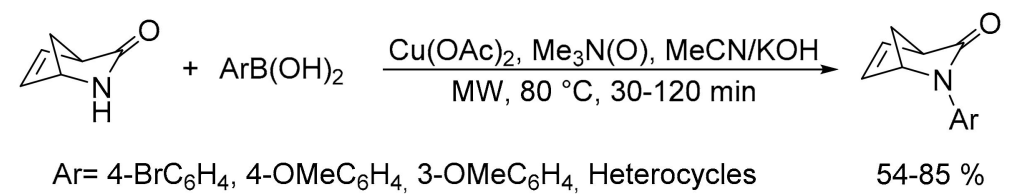

Scheme 58. $\mathrm{Cu}(\mathrm{OAc})_{2}$ catalyzed microwave-assisted synthesis of $\mathrm{N}$-aryl 2-azabicyclo[2.2.1]hept-5en-3-ones.

On the other hands, the $\mathrm{N}$-cyclopropylation of pyridinols promoted by copper(II) acetate $\left(\mathrm{Cu}(\mathrm{OAc})_{2}\right)$ under microwave irradiation have been described by Sharma and coworkers [118]. Pyridinols were reacted with cyclopropylboronic acid in the presence of equimolar concentration of $\mathrm{Cu}(\mathrm{OAc})_{2}$, with pyridine and NaHMDS as a base in toluene as solvent, the reaction mixture was then heated in a microwave oven at $120^{\circ} \mathrm{C}$ for relatively a long reaction time $(2-2.5 \mathrm{~h})$ leading to the synthesis of the desired products in moderate to very good yields, Scheme 59.

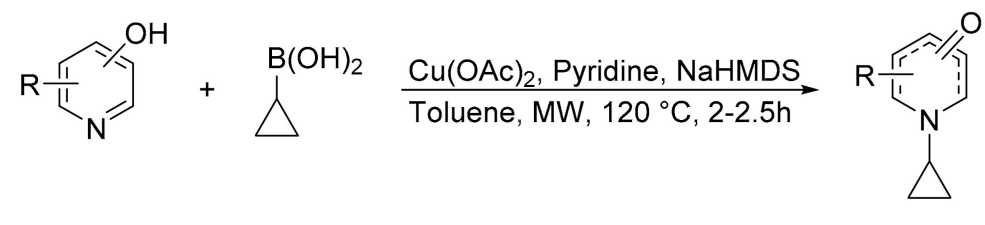

$\mathrm{R}=\mathrm{H}, \mathrm{Me}, \mathrm{OMe}, \mathrm{CN}$

$65-80 \%$

Scheme 59. $\mathrm{Cu}(\mathrm{OAc})_{2}$ catalyzed microwave-assisted $\mathrm{N}$-cyclopropylation reaction of pyridinols.

Under microwave irradiation, Al-Masum, M. et al. have reported on the use of dual catalysts composed of copper and palladium as useful cocatalyst for the amide styrylation reaction starting from potassium styryltrifluoroborates and amide compounds [119]. They have concluded the optimal conditions to be the use of catalytic amount of the dual catalysts, which is composed of copper(I) iodide (CuI) and [1,1'-Bis(di-tert-butylphosphino)ferrocene] dichloropalladium(II) $\left(\mathrm{PdCl}_{2}(\mathrm{~d} t \mathrm{bpf})\right)$ in the presence of potassium carbonate $\left(\mathrm{K}_{2} \mathrm{CO}_{3}\right)$ as base in 1,4-dioxane as solvent, the resulting reaction mixture was then heated in a microwave oven at $120{ }^{\circ} \mathrm{C}$ for $30 \mathrm{~min}$ to produce the amide styrylation derivatives in moderate to excellent yields, Scheme 60.

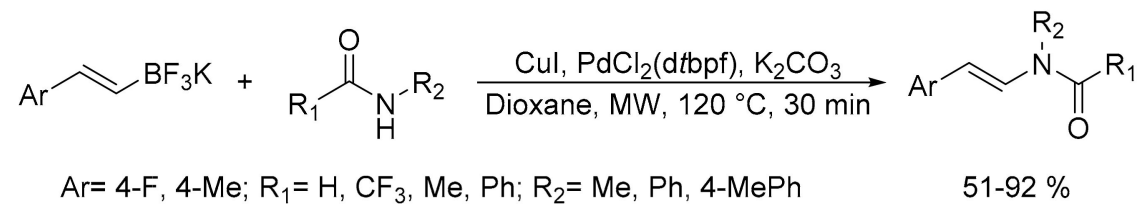

Scheme 60. Copper-palladium cocatalyzed microwave-assisted styrylation reactions of amides.

In a similar reaction, Chang, R.K. et al. have reported the synthesis of aryl amides via a concurrent tandem catalytic methodology of converting aryl chloride to an aryl 
iodide using halogen exchange reaction under microwave irradiation [120]. The author systematically optimized the reaction by applying a catalytic amount (20 mol \%) of copper(I) iodide (CuI) and $N, N^{\prime}$-cyclohexane-1,2-diamine as ligand, in the presence of $\mathrm{K}_{2} \mathrm{CO}_{3}$ as base in acetonitrile as solvent, the reaction mixture was then heated in a microwave oven at $200{ }^{\circ} \mathrm{C}$ for $45-60 \mathrm{~min}$, affording the title compounds in moderate to very good yields, Scheme 61.

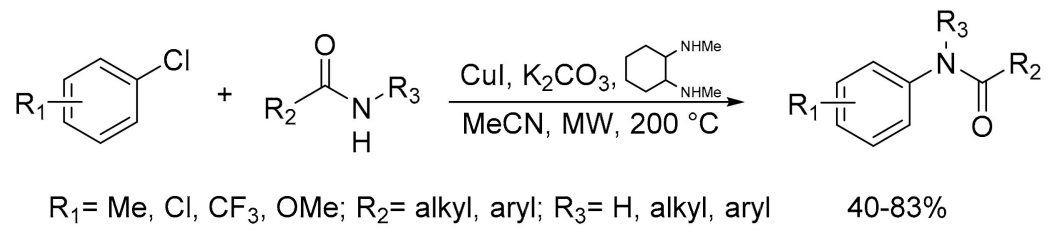

Scheme 61. CuI catalyzed microwave-assisted concurrent tandem catalytic amidation reaction of aryl chloride.

Under controlled microwave irradiation, Nishihara and coworkers have investigated the chloroamination reaction of styrene derivatives with chlorotrimethylsilane and $\mathrm{N}$ fluorobenzenesulfonimide [121]. The reaction has successfully achieved using catalytic amount $(10 \mathrm{~mol} \%)$ of $\mathrm{Cu}(\mathrm{acac})_{2}$ in dichloromethane as solvent, the reaction mixture was then heated in a microwave oven at $120{ }^{\circ} \mathrm{C}$ for $1 \mathrm{~h}$ to produce the desired products in moderate to excellent yields in high regioselectivity, Scheme 62.<smiles></smiles>

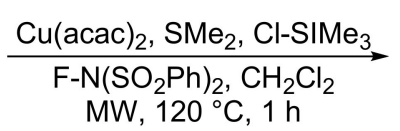
$\mathrm{MW}, 120^{\circ} \mathrm{C}, 1 \mathrm{~h}$<smiles>O=[R6]Oc1ccccc1C(Cl)CNS(=O)(=O)O</smiles>

$62-92 \%$

$\mathrm{R}=3-\mathrm{Me}, 4-\mathrm{Me}, 4-\mathrm{tBu}, 3-\mathrm{OMe}, 4-\mathrm{OAc}, 2-\mathrm{Cl}, 3-\mathrm{Cl}, 4-\mathrm{Cl}, 4-\mathrm{F}, 4-\mathrm{Br}, 3-\mathrm{CF}_{3}, 4-\mathrm{CF}_{3}$

Scheme 62. $\mathrm{Cu}(\mathrm{acac})_{2}$ catalyzed microwave-assisted chloroamination of styrenes with chlorotrimethylsilane and $\mathrm{N}$-fluorobenzenesulfonimide.

Using microwave heating process, Taj and coworkers have synthesized novel $N\left(N^{\prime}\right)$ arylbenzamidines starting from corresponding $\mathrm{N}$-arylbenzamides with ammonia or aniline in a one-pot reaction. The synthesized compounds showed good inhibition activity against several enzymes including acetylcholinesterase, butyrylcholinesterase, lipoxygenase, $\alpha$ glucosidase, urease, and reverse transcriptase with some selectivity for acetylcholinesterase, butyrylcholinesterase, and anti-HIV [122]. The reaction proceed smoothly using copper(II) oxide $(\mathrm{CuO})$ powder in neat condition with heating in microwave oven at $80^{\circ} \mathrm{C}$ for $15 \mathrm{~min}$, furnishing $N\left(N^{\prime}\right)$-arylbenzamidine derivatives in moderate to good yields, Scheme 63.<smiles>NNC(=O)c1ccccc1</smiles><smiles></smiles>

$\mathrm{R}=\mathrm{Ph}, \mathrm{H}$ $\mathrm{Ar}=2-\mathrm{H}_{2} \mathrm{NC}_{6} \mathrm{H}_{4}, 2-\mathrm{H}_{2} \mathrm{~N}-4-\mathrm{MeC}_{6} \mathrm{H}_{3}$ $2-\mathrm{H}_{2} \mathrm{~N}-3-\mathrm{MeC}_{6} \mathrm{H}_{3}, 2-\mathrm{H}_{2} \mathrm{~N}-4-\mathrm{ClC}_{6} \mathrm{H}_{3}$<smiles>[R]N=C(N[AlH2])c1ccccc1</smiles>

$60-77 \%$

Scheme 63. CuO catalyzed microwave-assisted synthesis of $N\left(N^{\prime}\right)$-arylbenzamidines.

Recyclable nanoparticles composed of three metals, nickel, copper, and iron $\left(\mathrm{NiCuFe}_{2} \mathrm{O}_{4}\right)$ has been developed and utilized for a microwave-assisted neat synthesis of bis-amide derivatives have been reported by Sarada, R. et al. [123]. They have concluded that the optimal reaction conditions achieved using catalytic amount (10 mol \%) of $\mathrm{NiCuFe}_{2} \mathrm{O}_{4}$ nanoparticles $\left(\mathrm{NiCuFe}_{2} \mathrm{O}_{4} \mathrm{NPs}\right)$ in the presence of silica gel, the resulting 
mixture was heated in a microwave oven at $100{ }^{\circ} \mathrm{C}$ for $4 \mathrm{~min}$ to obtain the desired products in excellent yields, Scheme 64.

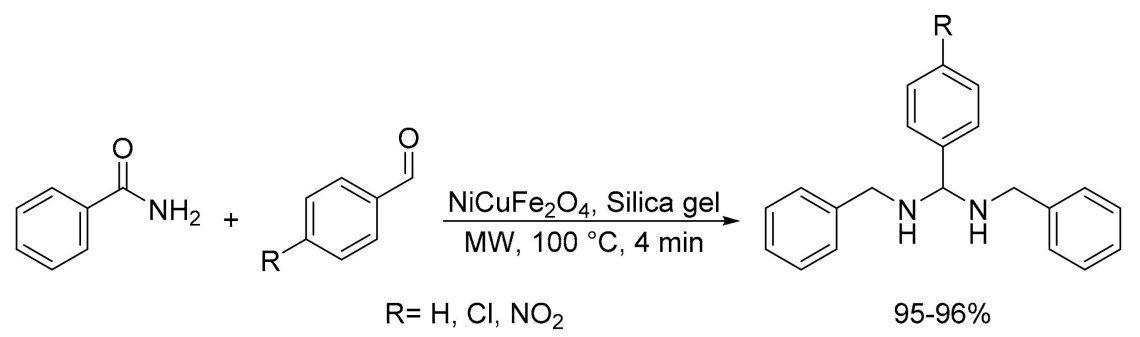

Scheme 64. $\mathrm{NiCuFe}_{2} \mathrm{O}_{4} \mathrm{NPs}$ catalyzed microwave-assisted synthesis of bis-amides.

Nematpour, M. and Abedi, E. have reported the synthesis of sulfonylidene-sulfonamide derivatives via one-pot reaction among three components: $N$-sulfonylketenimine, sodium arylsulfinates, and terminal alkynes under microwave irradiation [124]. The reaction being optimized to use a catalytic amount (10 mol \%) of copper(I) iodide (CuI), in the presence of triethyl amine $\left(\mathrm{Et}_{3} \mathrm{~N}\right)$ as a base and $\mathrm{DMF}$ as a solvent, the reaction mixture was irradiated in microwave oven at 900 Watt for $1 \mathrm{~h}$ furnishing sulfonylidene-sulfonamide derivatives in good to excellent yields, Scheme 65.

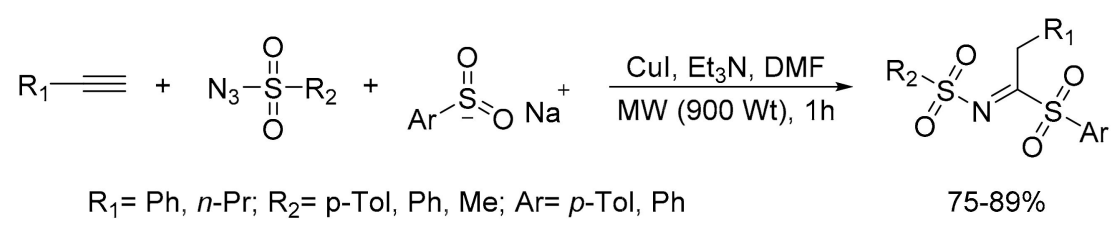

Scheme 65. CuI catalyzed microwave-assisted synthesis of sulfonylidene-sulfonamide derivatives.

Under controlled microwave irradiation technique, Shankaraiah and coworkers have developed novel copper(I)-complex [bis(tetrabutylammonium)di- $\mu$-iodo-diiododicuprate(I)] for the synthesis of $\alpha$-ketoamides starting from aryl methyl ketones and amines [125]. The reaction proceeds smoothly using a catalytic amount (20 mol \%) of the copper(I)-complex $(\mathrm{Cu}(\mathrm{I})$-complex) in the presence of molecular oxygen as oxidizing agent, and water as solvent, the reaction mixture was then heated in a microwave oven at $60^{\circ} \mathrm{C}$ for $10 \mathrm{~min}$ to produce the target compounds in moderate to excellent yields, Scheme 66.

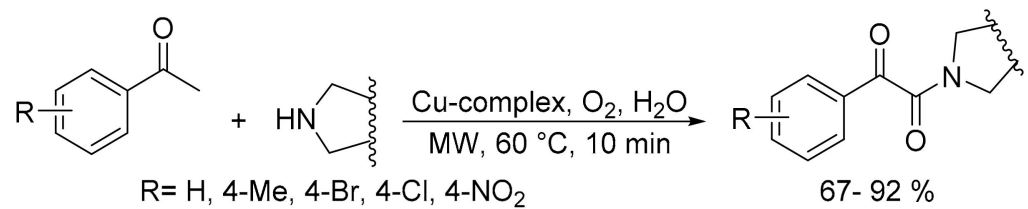

Scheme 66. $\mathrm{Cu}(\mathrm{I})$-complex catalyzed microwave synthesis of $\alpha$-ketoamides.

\subsection{Synthesis of Carbon-Chalcogen Bonds (C-O, C-S, C-Se, and C-Te)}

Copper based catalysts were used for carbon-chalcogen bonds (C-O, C-S, C-Se, and $\mathrm{C}-\mathrm{Te}$ ) formation under microwave irradiation. The generation of carbon-oxygen $(\mathrm{C}-\mathrm{O})$ bond has been developed as an efficient strategy for the synthesis of diaryl and alkyl aryl ethers via $O$-arylation and $O$-alkylation of phenols $[126,127]$. Two reaction pathways were proposed; the first one utilizing catalytic amount ( $5 \mathrm{~mol} \%$ ) of copper(I) bromide (CuBr) and 1,1-azobis(cyclohexane carbonitrile) (ACHN) as ligand in DMF as solvent [126], while the second reaction pathway through the use of a catalytic amount (5 mol \%) of copper(I) oxide with $\mathrm{Cs}_{2} \mathrm{CO}_{3}$ as base in $\mathrm{N}$-methyl-2-pyrrolidinone (NMP) as solvent [127], both reaction mixtures were heated in a microwave oven at $170{ }^{\circ} \mathrm{C}$ for $30 \mathrm{~min}$ to produce the diaryl and alkyl aryl ethers in moderate to excellent yields, Scheme 67. 


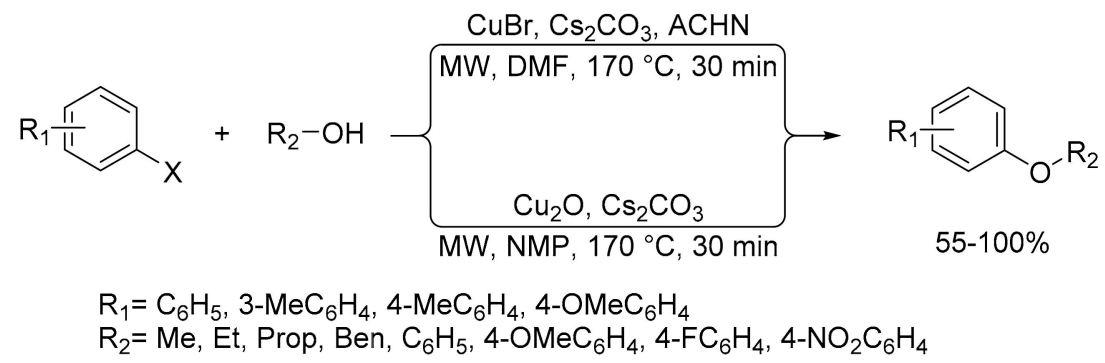

Scheme 67. Copper catalyzed microwave-assisted synthesis of diaryl and alkyl aryl ethers.

Another important carbon-heteroatom formation is the carbon-sulfur $(C-S)$ bond. Copper catalyze microwave assisted synthesis of $C-S$ bond have been well documented in the literature. Chen, Y.-A. et al. have reported the reaction of thiol derivatives with aryl iodides in water [128]. The authors have concluded that the best reaction conditions were to use a catalytic amount ( $5 \mathrm{~mol} \%$ ) of copper(II) oxide ( $\mathrm{CuO}), 1,10$-phenanthroline as ligand, and potassium tert-butoxide $(\mathrm{KO} t$-Bu) as base in water as solvent, the resulting mixture was then heated in a microwave oven at $120^{\circ} \mathrm{C}$ for $30 \mathrm{~min}$ to produce the desired products in good to excellent yields, Scheme 68.

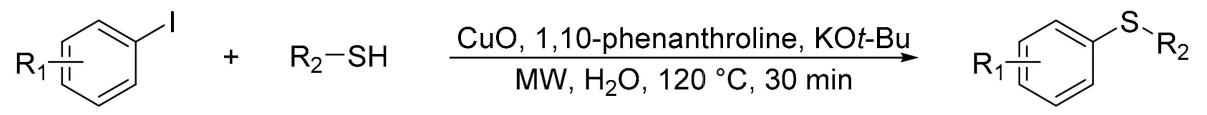

$\mathrm{R}_{1}=\mathrm{H}, 2-\mathrm{Me}$, 3-Me, 4-Me, 3-OMe, 4-OMe, 4-Cl, 4- $\mathrm{Br}, 3-\mathrm{NO}_{2}$, 3-Ac, 4-Ac $\mathrm{R}_{2}=\mathrm{C}_{6} \mathrm{H}_{5}, 4-\mathrm{MeC}_{6} \mathrm{H}_{4}, 4-\mathrm{ClC}_{6} \mathrm{H}_{4}, 4-\mathrm{MeOC}_{6} \mathrm{H}_{4}, 2-\mathrm{NH}_{2} \mathrm{C}_{6} \mathrm{H}_{4}$ $\left(\mathrm{CH}_{2}\right)_{11} \mathrm{Me}, \mathrm{Bn}, \mathrm{CH}_{2} \mathrm{CH}(\mathrm{Me}) \mathrm{Et}, \mathrm{Cy}$

Scheme 68. $\mathrm{CuO}$ catalyzed microwave-assisted generation of $\mathrm{Ar}-\mathrm{S}$ bond.

Using controlled microwave condition, Chiosis and coworkers have reported the use of a combination between copper(I) iodide (CuI) and phase transfer catalyst, such as tetrabutylammonium bromide $\left[(n-\mathrm{Bu})_{4} \mathrm{NBr}\right]$ as useful reagent for S-arylation of 8-mercaptoadenine [129]. The reaction proceed smoothly using sodium tert-butoxide (NaOt-Bu) as base in DMF as solvent, the reaction mixture was then heated under microwave irradiation at $190{ }^{\circ} \mathrm{C}$, the reaction required $1.5 \mathrm{~h}$ furnishing the desired products in low to excellent yields, Scheme 69.

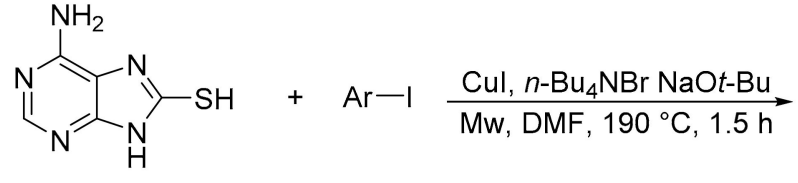

$\mathrm{Ar}=$ divers aryl and heteroaryl derivatives<smiles>Nc1ncnc2[nH]c(S[Ga])nc12</smiles>

Scheme 69. CuI catalyzed microwave-assisted C-S cross-coupling reaction between 8mercaptoadenine and aryl iodides.

Under controlled microwave-assisted synthesis, Braga and coworkers have developed copper(II) oxide nanoparticles (CuO NPs) to catalyze the generation of novel carbonchalcogen bonds, such as C-S, C-Se, and C-Te [130]. Diselenides, ditellurides, and disulfides were prepared via one-pot dimerization of organoyl iodides with elemental chalcogen $\left(\mathrm{Y}^{\circ}\right)$ using $\mathrm{CuO}$ NPs in the presence of $\mathrm{KOH}$ as base, DMSO as solvent, the resulting mixture was heated in a microwave oven at $80^{\circ} \mathrm{C}$ for $7-15 \mathrm{~min}$ and the desired products were obtained in moderate to excellent yields, Scheme 70. 


$$
\begin{aligned}
& 2 \mathrm{R}-\mathrm{I}+\mathrm{Y}^{\circ} \underset{\mathrm{MW}, \mathrm{DMSO}, 80^{\circ} \mathrm{C}, 7-15 \mathrm{~min}}{\longrightarrow} \mathrm{R}_{-\mathrm{Y}^{-}} \mathrm{Y}_{\mathrm{R}} \\
& \mathrm{R}=\text { alkyl, aryl, heteroaryl } \quad 51-94 \% \\
& Y=S, S e, T e
\end{aligned}
$$

Scheme 70. CuO NPs catalyzed microwave-assisted formation of carbon-chalcogen bonds.

Diaryl sulfide derivatives have been synthesized using cross-coupling reaction between trialkyltin arylselenides and arylbromides using copper catalyst resulted in unsymmetrical diarylselenides [131]. The reaction proceeds using a catalytic amount $(5 \mathrm{~mol} \%)$ of the copper catalyst $\left([(\mathrm{phen}) \mathrm{CuI}]_{2}\right)$ in DMF as solvent, the reaction mixture was then heated in microwave oven at $140{ }^{\circ} \mathrm{C}$ for $15-50$ min to produce diaryl sulfide derivatives in moderate to excellent yields, Scheme 71.

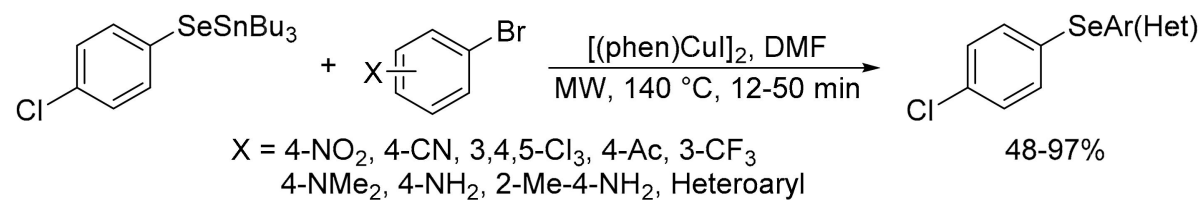

Scheme 71. [(phen)CuI $]_{2}$ catalyzed microwave-assisted synthesis of diaryl sulfide compounds.

In another study, Saba S. et al. have reported on the use of copper(I) iodide (CuI) for the synthesis of diorganyl chalcogenides $(\mathrm{S} / \mathrm{Se} / \mathrm{Te})$ starting from arylboronic acid derivatives under ligand and solvent-free conditions [132]. The reaction was done using catalytic amount ( $3 \mathrm{~mol} \%$ ) of $\mathrm{CuI}$ in DMSO as solvent, the reaction mixture was then heated in a microwave oven at $100{ }^{\circ} \mathrm{C}$ for $15 \mathrm{~min}$ to obtain the diorganyl chalcogenide derivatives in moderate to excellent yields, Scheme 72.

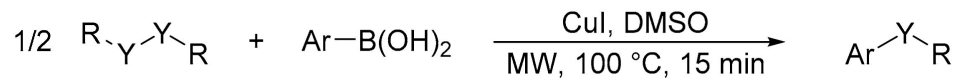

$$
\begin{aligned}
& \mathrm{Y}=\mathrm{S}, \mathrm{Se}, \mathrm{Te} ; \mathrm{R}=\left(\mathrm{CH}_{2}\right) \mathrm{CH}_{3}, \mathrm{C}_{6} \mathrm{H}_{5}, 4-\mathrm{MeC}_{6} \mathrm{H}_{4}, 3-\mathrm{ClC}_{6} \mathrm{H}_{4}, \quad 51-94 \% \\
& \text { 4- } \mathrm{ClC}_{6} \mathrm{H}_{4}, 2-\mathrm{OMeC}_{6} \mathrm{H}_{4} ; \mathrm{Ar}=4-\mathrm{ClC}_{6} \mathrm{H}_{4}, 2-\mathrm{OMeC}_{6} \mathrm{H}_{4}, 4-\mathrm{OMeC}_{6} \mathrm{H}_{4} \text {, } \\
& \text { 3- } \mathrm{NO}_{2} \mathrm{C}_{6} \mathrm{H}_{4}, 3-\mathrm{NH}_{2} \mathrm{C}_{6} \mathrm{H}_{4}, 4-\mathrm{AcC}_{6} \mathrm{H}_{4} \text {, 2-Naphthyl }
\end{aligned}
$$

Scheme 72. CuI catalyzed microwave-assisted synthesis of diorganyl chalcogenides.

Under microwave assisted condition, Bhargava and coworkers have reported on the synthesis of solketal from glycerol using copper mordenite (Cu-Mor) [133]. Cu-Mor were used to promote the cycloaddition reaction between glycerol and acetone in a microwave oven at $100{ }^{\circ} \mathrm{C}$ for 15 min leading to $95 \%$ conversion with $98 \%$ selectively for solketal, Scheme 73.

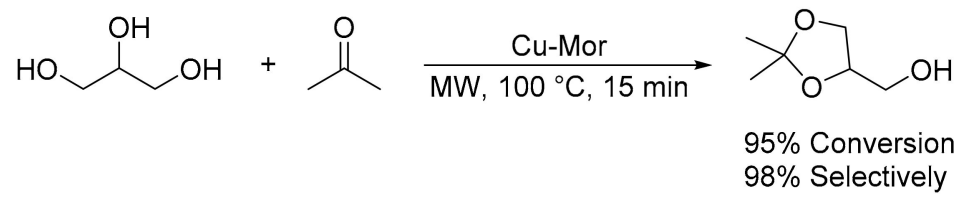

Scheme 73. Cu-Mor promotes microwave-assisted acetalization of glycerol.

\subsection{Miscellaneous Synthesis}

Copper based catalysts have been utilized for a wide range of organic transformations; herby a selection of recently published important transformation carried out under microwave irradiation. Symmetrical and asymmetrical diaryl sulfones have been synthesized using copper(II) triflate $\left(\mathrm{Cu}(\mathrm{OTf})_{2}\right)$ under microwave irradiation [134]. Nandi, G.C. has reported the coupling between sodium salt of sulfinic acids with aryl boronic acid derivatives in the presence of $\mathrm{Cu}(\mathrm{OTf})_{2}$ as catalyst and 2,2'-bipyridyl as ligand in dichloroethane (DCE) as solvent, the resulting mixture was then heated in a microwave oven at $120^{\circ} \mathrm{C}$ for 20-30 min furnishing diaryl sulfones in moderate to very good yields, Scheme 74 . 


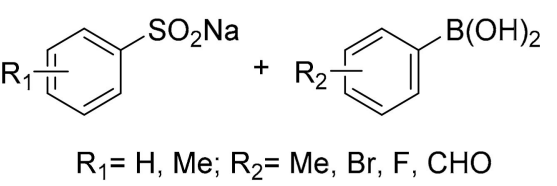

$\underset{\mathrm{MW}, 120^{\circ} \mathrm{C}, 20-30 \mathrm{~min}}{\stackrel{\mathrm{Cu}(\mathrm{OTf})_{2}, 2,2^{\prime}-\mathrm{Bipy}, \mathrm{DCE}}{\longrightarrow}}$

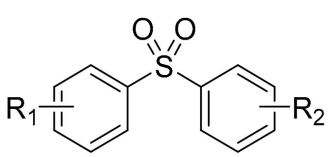

$41-81 \%$

Scheme 74. $\mathrm{Cu}(\mathrm{OTf})_{2}$ catalyzed microwave-assisted synthesis of diaryl sulfones.

Under controlled microwave irradiation condition, Jha and coworkers have developed new strategy for the synthesis of novel substituted acetophenones via hydration of terminal aryl acetylenes [135]. The authors have concluded that the reaction proceed smoothly using a catalytic amount $(2.5 \mathrm{~mol} \%)$ of $\mathrm{Cu}(\mathrm{OTf})_{2}$ in $\mathrm{AcOH} / \mathrm{H}_{2} \mathrm{O}$ as a solvent, and the resulting mixture was then heated in a microwave oven at $110{ }^{\circ} \mathrm{C}$ for $2-15$ min producing substituted acetophenones in low to excellent yields, Scheme 75.<smiles>C#Cc1cc[R]cc1</smiles>

$\mathrm{R}=\mathrm{H}, 4-\mathrm{Me}, 4-\mathrm{Et}, 4-\mathrm{OMe}$<smiles>[R]=[Pt]c1ccc(C(C)=O)cc1</smiles>

$38-94 \%$

Scheme $75 . \mathrm{Cu}(\mathrm{OTf})_{2}$ catalyzed microwave-assisted synthesis of substituted acetophenones.

In another study, Silaghi-Dumitrescu and coworkers have synthesized aminophenothiazine derivatives under microwave-assisted amination procedure [136]. Various hallo substituted 10-alkyl-10H-phenothiazines were aminated using catalytic amount ( $5 \mathrm{~mol} \%$ ) of $\mathrm{Cu}_{2} \mathrm{O}$, aqueous ammonia $\left(\mathrm{NH}_{3} / \mathrm{H}_{2} \mathrm{O}\right)$ solution and $N$-methyl-2-pyrrolidinone (NMP), the resulting mixture was then heated in a microwave oven at $120{ }^{\circ} \mathrm{C}$ for $2 \mathrm{~h}$ furnishing the target compounds in low to excellent yields, Scheme 76.

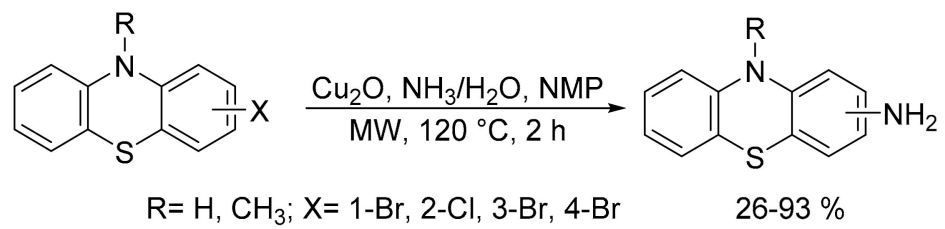

Scheme 76. $\mathrm{Cu}_{2} \mathrm{O}$ catalyzed microwave amination of hallo-10-alkyl-10H-phenothiazines.

Aryl halides have been converted into various derivatives of phenol using copper(II) catalyst under microwave-assisted hydroxylation reaction [137]. The reaction proceed smoothly using copper(II) chloride $\left(\mathrm{CuCl}_{2}\right)$ as catalyst, $\mathrm{KOH}$ as base and tetrabutylammonium bromide $\left[(n-\mathrm{Bu})_{4} \mathrm{NBr}\right]$ as phase transfer catalyst and L-proline lithium salt as ligand, the resulting mixture was then heated in a microwave at $120{ }^{\circ} \mathrm{C}$ for $40 \mathrm{~min}$ to produce phenol derivatives in moderate to excellent yield, Scheme 77.

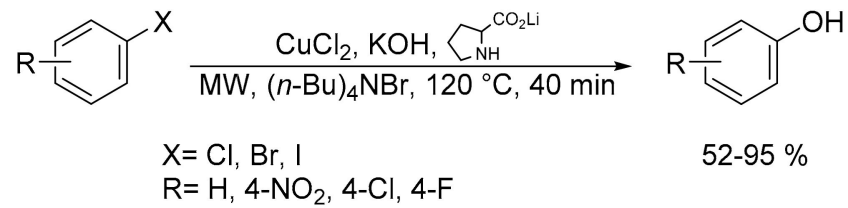

Scheme 77. $\mathrm{CuCl}_{2}$ catalyzed microwave-assisted hydroxylation of aryl halides.

Aryl halides were converted into the corresponding nitro derivatives via coppercatalyzed microwave-assisted nitration using nitrite salts $\left(n-\mathrm{Bu}_{4} \mathrm{NNO}_{2}\right)$ [138]. A systematic optimization of the reaction has resulted in the use of catalytic amount (10 mol \%) of $\mathrm{CuI}, \mathrm{N}, N^{\prime}$-dimethylethylenediamine as ligand, and $n-\mathrm{Bu}_{4} \mathrm{NNO}_{2}$ as nitrite salt, the reaction 
mixture was then heated in a microwave oven at $120{ }^{\circ} \mathrm{C}$ for $10 \mathrm{~min}$ to produce nitrobenzene derivatives in low to excellent yield, Scheme 78 .

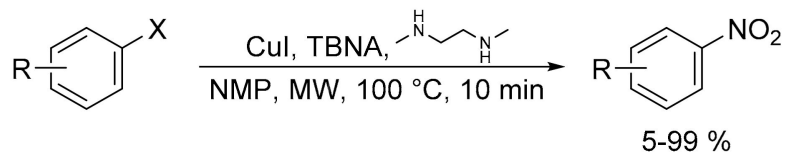

$\mathrm{X}=\mathrm{Br}, \mathrm{I}$

$5-99 \%$

$\mathrm{R}=\mathrm{H}, 2-\mathrm{OMe}, 3-\mathrm{OMe}, 4-\mathrm{OMe}, 2-\mathrm{NH}_{2}, 4-\mathrm{NH}_{2}, m-X y l e n e$

Scheme 78. CuI catalyzed microwave-assisted nitration of aryl halides.

A combination between microwave and ultrasound irradiation (CMUI) was used to assist the reduction reaction of nitrobenzene derivatives to the corresponding anilines using copper(II) acetate nanoparticles $\left(\mathrm{Cu}(\mathrm{OAc})_{2} \mathrm{NPs}\right)$ [139]. The reduction reaction has been optimized using $30 \mathrm{~mol} \%$ of $\mathrm{Cu}(\mathrm{OAc})_{2} \mathrm{NPs}$, hydrazine hydrate $\left(\mathrm{NH}_{2}-\mathrm{NH}_{2} \cdot \mathrm{H}_{2} \mathrm{O}\right)$ in ethylene glycol, the resulting mixture was then heated in a microwave oven at $120-125^{\circ} \mathrm{C}$ for short reaction time (4-6.5 min), leading aniline derivatives in excellent yields, Scheme 79.

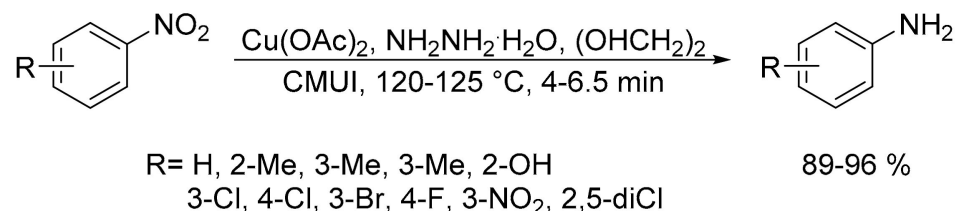

Scheme 79. $\mathrm{Cu}(\mathrm{OAc})_{2} \mathrm{NPs}$ catalyzed microwave-assisted reduction of nitrobenzenes to aniline derivatives.

Under controlled microwave-assisted reaction, Montel, S. et al. have reported the Conia-ene cyclization of tethered stabilized nucleophiles using neutral conditions, which is leading to obtain high selective 5-exo cyclized derivatives [140]. The reaction has proceed in an efficient way for both internal and terminal alkynes using catalytic amount $(1 \mathrm{~mol} \%)$ of the cationic copper catalyst $\left(\left[\mathrm{Cu}(\mathrm{Phen})\left(\mathrm{PPh}_{3}\right)_{2}\right] \mathrm{NO}_{3}\right)$ and calcium hydride $\left(\mathrm{CaH}_{2}\right)$ as a base in dioxane as solvent, the resulting mixture was then heated in a microwave oven at $150{ }^{\circ} \mathrm{C}$ for $20-180 \mathrm{~min}$ furnishing the desired cyclized product in low to excellent yields, Scheme 80.

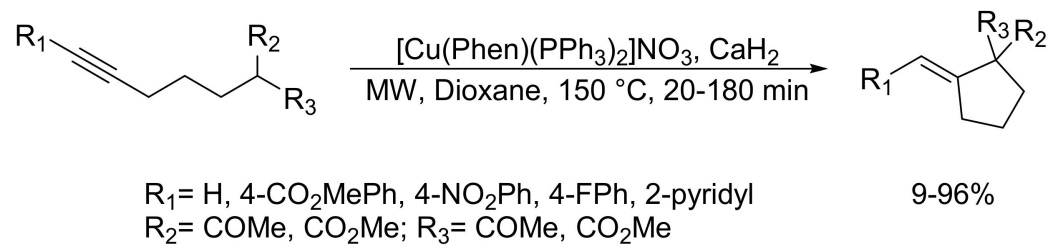

Scheme 80. $\left[\mathrm{Cu}(\mathrm{Phen})\left(\mathrm{PPh}_{3}\right)_{2}\right] \mathrm{NO}_{3}$ catalyzed microwave-assisted Conia-ene cyclization of tethered stabilized nucleophiles.

A hydrogenation reaction of furfural to furfuryl alcohol has been developed by LopezSanchez and coworkers under microwave irradiation [141]. They have used a novel copper absorbed on titanium dioxide $\left(\mathrm{Cu} / \mathrm{TiO}_{2}\right)$ as catalyst in cyclopentyl methyl ether (CPME) as solvent, the resulting mixture was then heated in a microwave oven at $125^{\circ} \mathrm{C}$ for relatively long reaction time $(3 \mathrm{~h})$, using 10 bar of the hydrogen gas $\left(\mathrm{H}_{2}\right)$ pressure. The reaction showed $100 \%$ conversion and $99 \%$ selectivity of furfuryl alcohol under mild reaction conditions, Scheme 81. 


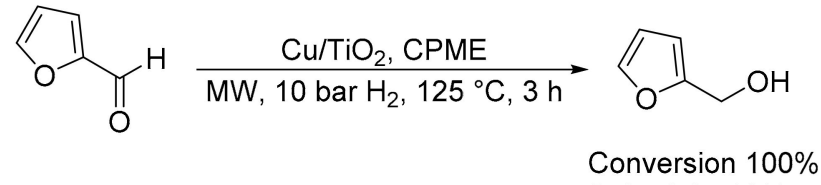

Selectivity $99 \%$

Scheme 81. $\mathrm{Cu} / \mathrm{TiO}_{2}$ catalyzed microwave-assisted reduction of furfural to furfuryl alcohol.

\section{Conclusions}

Copper-catalyzed cross-coupling reactions to generate carbon-carbon $(\mathrm{C}-\mathrm{C})$ and carbon-heteroatom bonds, such as $\mathrm{C}-\mathrm{N}, \mathrm{C}-\mathrm{O}, \mathrm{C}-\mathrm{S}, \mathrm{C}-\mathrm{Se}$, and $\mathrm{C}-\mathrm{Te}$, under microwave controlled conditions has proved to be safe in handling and cost effectiveness compared with conventional heating method. Moreover, it has gain some advantageous in comparison to the use of noble metal such as palladium based catalyst for cross-coupling in both conventional or microwave heating, due to the low cost and ready availability of copper catalysts. In many discussed reactions, the use of the microwave heating technology have not only shorten the reaction time, but it was essential for a wider range of functional groups and to obtain the target compounds in higher yields. The catalytic materials showed variable catalyst loading, which ranging from little high load (30 mol \%) to very low catalyst loading percentage $(0.1 \mathrm{~mol} \%)$. Several copper solid support catalysts, including nanomaterials, such as nanoparticles and nanocubes, have been developed for the microwave-assisted cross-coupling transformations. These solid support catalysts were found to be useful as homogenous as well as heterogeneous catalysts with advantage of being recyclable for consecutive use.

Funding: This research was funded by Arab-German Young Academy of Sciences and Humanities (AGYA), grants number TP_2020_04 \& TP_2020_22.

Conflicts of Interest: The author declares no conflict of interest.

\section{References}

1. Ruiz-Castillo, P.; Buchwald, S.L. Applications of palladium-catalyzed C-N cross-coupling reactions. Chem. Rev. 2016, 116, 12564-12649. [CrossRef] [PubMed]

2. Giri, R.; Brusoe, A.; Troshin, K.; Wang, J.Y.; Font, M.; Hartwig, J.F. Mechanism of the Ullmann biaryl ether synthesis catalyzed by complexes of anionic ligands: Evidence for the reaction of iodoarenes with ligated anionic CuI intermediates. J. Am. Chem. Soc. 2018, 140, 793-806. [CrossRef] [PubMed]

3. Salih, K.S.M.; Baqi, Y. Microwave-assisted palladium-catalyzed cross-coupling reactions: Generation of carbon-carbon bond. Catalysts 2020, 10, 4. [CrossRef]

4. Altman, R.A.; Buchwald, S.L. Cu-catalyzed Goldberg and Ullmann reactions of aryl halides using chelating N-and O-based ligands. Nat. Protoc. 2007, 2, 2474-2479. [CrossRef]

5. De la Hoz, A.; Loupy, A. Microwaves in Organic Synthesis, 3rd ed.; Wiley-VCH Verlag GmbH \& Co. KGaA: Weinheim, Germany, 2013. [CrossRef]

6. Gawande, M.B.; Shelke, S.N.; Zboril, R.; Varma, R.S. Microwave-assisted chemistry: Synthetic applications for rapid assembly of nanomaterials and organics. Acc. Chem. Res. 2014, 47, 1338-1348. [CrossRef]

7. Ullmann, F.; Bielecki, J. Ueber Synthesen in der Biphenylreihe. Berichte der Deutschen Chemischen Gesellschaft 1901, 34, $2174-2185$. [CrossRef]

8. Ullmann, F. Ueber eine neue Bildungsweise von Diphenylaminderivaten. Berichte der Deutschen Chemischen Gesellschaft 1903, 36, 2382-2384. [CrossRef]

9. Ullmann, F. Ueber eine neue Darstellungsweise von Phenyläthersalicylsäure. Berichte der Deutschen Chemischen Gesellschaft 1904, 37, 853-854. [CrossRef]

10. Ullmann, F.; Sponagel, P. Ueber die Phenylirung von Phenolen. Berichte der Deutschen Chemischen Gesellschaft 1905, 38, 2211-2212. [CrossRef]

11. Goldberg, I. Ueber Phenylirungen bei Gegenwart von Kupfer als Katalysator. Berichte der Deutschen Chemischen Gesellschaft 1906, 39, 1691-1692. [CrossRef]

12. Baqi, Y.; Müller, C.E. Antithrombotic $\mathrm{P}_{2} \mathrm{Y}_{12}$ receptor antagonists: Recent developments in drug discovery. Drug Discov. Today 2019, 24, 325-333. [CrossRef] [PubMed]

13. Baqi, Y. Anthraquinones as a privileged scaffold in drug discovery targeting nucleotide-binding proteins. Drug Discov. Today 2016, 21, 1571-1577. [CrossRef] [PubMed] 
14. Baqi, Y. Ecto-nucleotidase inhibitors: Recent developments in drug discovery. Mini Rev. Med. Chem. 2015, 15, 21-33. [CrossRef] [PubMed]

15. Baqi, Y.; Atzler, K.; Köse, M.; Glänzel, M.; Müller, C.E. High-affinity, non-nucleotide-derived competitive antagonists of platelet P2Y 12 receptors. J. Med. Chem. 2009, 52, 3784-3793. [CrossRef]

16. Baqi, Y.; Weyler, S.; Iqbal, J.; Zimmermann, H.; Müller, C.E. Structure-activity relationships of anthraquinone derivatives derived from bromaminic acid as inhibitors of ectonucleoside triphosphate diphosphohydrolases (E-NTPDases). Purinerg. Signal. 2009, 5, 91-106. [CrossRef]

17. Baqi, Y.; Lee, S.-Y.; Iqbal, J.; Ripphausen, P.; Lehr, A.; Scheiff, A.B.; Zimmermann, H.; Bajorath, J.; Müller, C.E. Development of potent and selective inhibitors of ecto-5'-nucleotidase based on an anthraquinone scaffold. J. Med. Chem. 2010, 53, 2076-2086. [CrossRef]

18. Baqi, Y.; Hausmann, R.; Rosefort, C.; Rettinger, J.; Schmalzing, G.; Müller, C.E. Discovery of potent competitive antagonists and positive modulators of the $\mathrm{P} 2 \times 2$ receptor. J. Med. Chem. 2011, 54, 817-830. [CrossRef]

19. Fiene, A.; Baqi, Y.; Malik, E.M.; Newton, P.; Li, W.; Lee, S.Y.; Hartland, E.L.; Müller, C.E. Inhibitors for the bacterial ectonucleotidase Lp1NTPDase from Legionella pneumophila. Bioorg. Med. Chem. 2016, 24, 4363-4371. [CrossRef]

20. Weyler, S.; Baqi, Y.; Hillmann, P.; Kaulich, M.; Hunder, A.M.; Müller, I.A.; Müller, C.E. Combinatorial synthesis of anilinoanthraquinone derivatives and evaluation as non-nucleotide-derived $\mathrm{P}_{2} \mathrm{Y}_{2}$ receptor antagonists. Bioorg. Med. Chem. Lett. 2008, 18, 223-227. [CrossRef]

21. Baqi, Y.; Müller, C.E. Rapid and efficient microwave-assisted copper(0)-catalyzed Ullmann coupling reaction: General access to anilinoanthraquinone derivatives. Org. Lett. 2007, 9, 1271-1274. [CrossRef]

22. Baqi, Y.; Müller, C.E. Synthesis of alkyl- and aryl-amino-substituted anthraquinone derivatives by microwave-assisted copper(0)catalyzed Ullmann coupling reactions. Nat. Protoc. 2010, 5, 945-953. [CrossRef] [PubMed]

23. Wang, N.; Faber, E.B.; Georg, G.I. Synthesis and spectral properties of 8-anilinonaphthalene-1-sulfonic acid (ANS) derivatives prepared by microwave-assisted copper(0)-catalyzed Ullmann reaction. ACS Omega 2019, 4, 18472-18477. [CrossRef] [PubMed]

24. Park, A.R.; Yum, E.K. Introduction of diverse functional groups to isoquinolines by microwave-assisted transition metal-catalyzed coupling reactions. Bull. Korean Chem. Soc. 2018, 39, 1259-1265. [CrossRef]

25. Gavade, S.; Shingare, M.; Mane, D. Microwave assisted, solvent- and ligand-free copper catalyzed n-arylation of phenylurea with aryl halides. Bull. Korean Chem. Soc. 2011, 32, 4167-4170. [CrossRef]

26. Gavade, S.N.; Balaskar, R.S.; Shingare, M.; Mane, M.S.; Pabrekar, P.N.; Shingare, M.S.; Mane, D.V. Microwave assisted, ligand free, copper catalyzed reaction of aryl halides with phenyl urea. Chin. Chem. Lett. 2011, 22, 292-295. [CrossRef]

27. Liu, Z.-J.; Vors, J.-P.; Gesing, E.R.F.; Bolm, C. Microwave-assisted solvent- and ligand-free copper-catalysed cross-coupling between halopyridines and nitrogen nucleophiles. Green Chem. 2011, 13, 42-45. [CrossRef]

28. Oh, Y.J.; Yum, E.K. Microwave-assisted transition metal-catalyzed coupling approach to indazole diversity. Bull. Korean Chem. Soc. 2019, 40, 404-411. [CrossRef]

29. Kumari, S.; Shakoor, S.M.A.; Bajaj, K.; Nanjegowda, S.H.; Mallu, P.; Sakhuja, R. Copper-catalyzed C-N/C-O coupling in water: A facile access to N-coumaryl amino acids and fluorescent tyrosine \& lysine labels. Tetrahedron Lett. 2016, 57, 2732-2736. [CrossRef]

30. Kwon, J.-K.; Lee, J.-H.; Kim, T.-S.; Yum, E.-K.; Park, H.-J. Diversification of indoles via microwave-assisted ligand-free coppercatalyzed N-arylation. Bull. Korean Chem. Soc. 2016, 37, 1927-1933. [CrossRef]

31. Breugst, M.; Reissig, H.U. The Huisgen reaction: Milestones of the 1,3-dipolar cycloaddition. Angew. Chem. Int. Ed. Engl. 2020, 59, 12293-12307. [CrossRef]

32. Pradeep, M.; Vishnuvardhan, M.; Krishna, V.B.; Raju, R.M. An efficient microwave assisted synthesis and antimicrobial activty of 1,2,3-triazolyl-pyrrolidinyl-quinolinolines. Russ. J. Gen. Chem. 2019, 89, 313-318. [CrossRef]

33. Arrjane, M.; Slassi, S.; Tazi, B.; Maouloua, M.; Amine, A. Novel series of acridone-1,2,3-triazole derivatives: Microwave-assisted synthesis, DFT study and antibacterial activities. J. Chem. Sci. 2019, 131, 85. [CrossRef]

34. Hernández-López, H.; Leyva-Ramos, S.; Moncada-Martínez, R.D.; López, J.A.; Cardoso-Ortiz, J. Copper(I)-catalyzed azide-alkyne cycloaddition microwave-assisted: Preparation of 7-(4-substituted-1H-1,2,3-triazol-1-yl)-fluoroquinolones. ChemistrySelect 2019, 4, 11899-11902. [CrossRef]

35. Da Silva Dias, C.; de Melo Lima, T.; Lima, C.G.S.; Zuekrman-Schpector, J.; Schwab, R.S. CuO nanoparticles as an efficient heterogeneous catalyst for the 1,3-dipolar cycloaddition of dicarbonyl compounds to azides. ChemistrySelect 2018, 3, 6195-6202. [CrossRef]

36. Ashok, D.; Gundu, S.; Aamate, V.K.; Devulapally, M.G. Microwave-assisted synthesis, antioxidant and antimicrobial evaluation of 2-indolinone-based bis-1,2,3-triazole derivatives. Mol. Divers. 2018, 22, 57-70. [CrossRef]

37. Mahmoud, A.G.; da Silva, M.F.C.G.; Sokolnicki, J.; Smoleński, P.; Pombeiro, A.J.L. Hydrosoluble Cu(I)-DAPTA complexes: Synthesis, characterization, luminescence thermochromism and catalytic activity for microwave-assisted three-component azide-alkyne cycloaddition click reaction. Dalton Trans. 2018, 47, 7290-7299. [CrossRef]

38. Yuan, J.-W.; Qu, L.-B. Efficient synthesis of novel $\beta$-sitosterol scaffolds containing 1,2,3-triazole via copper (I)-catalyzed click reaction under microwave irradiation. Zeitschrift für Naturforschung B 2017, 72, 717-724. [CrossRef]

39. Xavier, M.C.D.F.; Xavier, D.M.; Seus, N.; Lenardão, E.J.; Perin, G.; Alves, D. Microwave assisted rapid synthesis of (arylselanyl)phenyl-1h-1,2,3-triazoles by copper catalyzed 1,3-dipolar cycloaddition. Curr. Microwave Chem. 2016, 3, 14-23. [CrossRef] 
40. Steenackers, H.; Ermolat'ev, D.; Trang, T.T.T.; Savalia, B.; Sharma, U.K.; De Weerdt, A.; Shah, A.; Vanderleyden, J.; Van der Eycken, E.V. Microwave-assisted one-pot synthesis and anti-biofilm activity of 2-amino-1H-imidazole/triazole conjugates. Org. Biomol. Chem. 2014, 12, 3671-3678. [CrossRef]

41. De Andrade, P.; Galo, O.A.; Carvalho, M.R.; Lopes, C.D.; Carneiro, Z.A.; Sesti-Costa, R.; de Melo, D.B.; Silva, J.S.; Carvalho, I. 1,2,3-Triazole-based analogue of benznidazole displays remarkable activity against Trypanosoma cruzi. Bioorg. Med. Chem. 2015, 23, 6815-6826. [CrossRef]

42. Khan, A.K.; Vasconcelos, S.N.S.; Carrau, G.; Stefani, H.A. Microwave-assisted synthesis of $\beta-1,2,3$-triazolyl- $\alpha$-amino esters. J. Braz. Chem. Soc. 2015, 26, 1457-1465. [CrossRef]

43. Ding, F.; Ji, L.; William, R.; Chai, H.; Liu, X.-W. Design and synthesis of multivalent neoglycoconjugates by click conjugations. Beilstein J. Org. Chem. 2014, 10, 1325-1332. [CrossRef] [PubMed]

44. Potewar, T.M.; Petrova, K.T.; Barros, M.T. Efficient microwave assisted synthesis of novel 1,2,3-triazole-sucrose derivatives by cycloaddition reaction of sucrose azides and terminal alkynes. Carbohydr. Res. 2013, 379, 60-67. [CrossRef] [PubMed]

45. Worrell, B.T.; Malik, J.A.; Fokin, V.V. Direct evidence of a dinuclear copper intermediate in Cu(I)-catalyzed azide-alkyne cycloadditions. Science 2013, 340, 457-460. [CrossRef] [PubMed]

46. Elazab, H.A.; Radwan, M.A.; El-Idreesy, T.T. Facile microwave-assisted synthetic approach to palladium nanoparticles supported on copper oxide as an efficient catalyst for Heck and Sonogashira cross-coupling reactions. Int. J. Nanosci. 2019, 18, 1850032. [CrossRef]

47. Tsai, W.-T.; Lin, Y.-Y.; Wang, Y.-J.; Lee, C.-F. Special topic microwave-assisted copper-catalyzed cross-coupling reaction of alkynes with aryl iodides and vinyl halides. Synthesis 2012, 44, 1507-1510. [CrossRef]

48. Lei, Y.; Hu, T.; Wu, X.; Wu, Y.; Xiang, H.; Sun, H.; You, Q.; Zhang, X. Microwave-assisted copper- and palladium-catalyzed sonogashira-type coupling of aryl bromides and iodides with trimethylsilylacetylene. Tetrahedron Lett. 2016, 57, 1100-1103. [CrossRef]

49. Babu, S.A.; Saranya, S.; Rohit, K.R.; Anilkumar, G. Ligand-free Cu-catalyzed Suzuki coupling of alkynyl bromides with boronic acids in ethanol under microwave irradiation. ChemistrySelect 2019, 4, 1019-1022. [CrossRef]

50. Elazab, H.A.; Sadek, M.A. Microwave-assisted synthesis of palladium nanoparticles supported on copper oxide in aqueous medium as an efficient catalyst for Suzuki cross-coupling reaction. Adsorpt. Sci. Technol. 2018, 36, 1352-1365. [CrossRef]

51. Ibrahim, M.A. Microwave-assisted synthesis of a -aryl malonates: Key intermediates for the preparation of azaheterocycles. Arabian J. Chem. 2016, 9, S1973-S1983. [CrossRef]

52. Jha, A.K.; Jain, N. Microwave-assisted ortho-alkylation of azine N-oxides with N-tosylhydrazones catalyzed by copper(I) iodide. Chem. Commun. 2016, 52, 1831-1834. [CrossRef] [PubMed]

53. Lauder, K.; Toscani, A.; Scalacci, N.; Castagnolo, D. Synthesis and reactivity of propargylamines in organic chemistry. Chem. Rev. 2017, 117, 14091-14200. [CrossRef] [PubMed]

54. Udaykumar, B.; Periasamy, M. Synthesis of propargylamines via Michael dddition using methyl vinyl ketone derivatives, 1-alkynes, and secondary amines catalyzed by copper (I) halides. ACS Omega 2019, 4, 21587-21595. [CrossRef] [PubMed]

55. Koradin, C.; Polborn, K.; Knochel, P. Enantioselective synthesis of propargylamines by copper-catalyzed addition of alkynes to enamines. Angew. Chem., Int. Ed. 2002, 41, 2535-2538. [CrossRef]

56. Pereshivko, O.P.; Peshkov, V.A.; Van der Eycken, E.V. Unprecedented Cu(I)-catalyzed microwave-assisted three-component coupling of a ketone, an alkyne, and a primary amine. Org. Lett. 2010, 12, 2638-2641. [CrossRef]

57. Pierce, C.J.; Nguyen, M.; Larsen, C.H. Copper/Titanium catalyst forms fully substituted carbon centers from the direct coupling of acyclic ketones, amines, and alkynes. Angew. Chem. 2012, 124, 12455-12458. [CrossRef]

58. Shah, A.P.; Sharma, A.S.; Jain, S.; Shimpi, N.G. Microwave assisted one pot three component synthesis of propargylamine, tetra substituted propargylamine and pyrrolo[1,2-a]quinolines using CuNPs@ZnO-PTh as a heterogeneous catalyst. N. J. Chem. 2018, 42, 8724-8737. [CrossRef]

59. Kashid, V.S.; Balakrishna, M.S. Microwave-assisted copper(I) catalyzed $\mathrm{A}^{3}$-coupling reaction: Reactivity, substrate scope and the structural characterization of two coupling products. Catal. Commun. 2018, 103, 78-82. [CrossRef]

60. Sharma, A.S.; Kaur, H.; Barot, N. Microwave-assisted facile synthesis of propargylamine library by robust nitro functionalized cross-linked polystyrene resin supported Cu NPs. J. Phys. Org. Chem. 2017, 31, e3749. [CrossRef]

61. Li, X.; Chen, N.; Xu, J. Microwave-assisted CuCl-catalyzed three-component reactions of alkynes, aldehydes, and amino alcohols. Synthesis 2019, 51, 3336-3344. [CrossRef]

62. Bariwal, J.B.; Ermolat'ev, D.S.; Van der Eycken, E.V. Efficient microwave-assisted synthesis of secondary alkylpropargylamines by using $\mathrm{A}^{3}$-coupling with primary aliphatic amines. Chem. Eur. J. 2010, 16, 3281-3284. [CrossRef] [PubMed]

63. Ermolat'ev, D.S.; Feng, H.; Song, G.; Van der Eycken, E.V. Copper(I)-catalyzed decarboxylative coupling of propiolic acids with secondary amines and aldehydes. Eur. J. Org. Chem. 2014, 5346-5350. [CrossRef]

64. Feng, H.; Ermolat'ev, D.S.; Song, G.; Van der Eycken, E.V. Synthesis of symmetric 1,4-diamino-2-butynes via a Cu(I)-catalyzed one-pot $\mathrm{A}^{3}$-coupling/decarboxylative coupling of a propiolic acid, an aldehyde, and an amine. J. Org. Chem. 2012, 77, 5149-5154. [CrossRef]

65. Feng, H.; Ermolat'ev, D.S.; Song, G.; Van der Eycken, E.V. Microwave-assisted decarboxylative three-component coupling of a 2-oxoacetic acid, an amine, and an alkyne. J. Org. Chem. 2011, 76, 7608-7613. [CrossRef] 
66. Feng, H.; Zhao, P.; Huang, L.; Sun, Z.; Tong, M. Highly selective synergistic copper(I/II)-catalyzed $\mathrm{A}^{3}$ cross coupling/decarboxylative $\mathrm{A}^{3}$ domino reactions in water. Asian J. Org. Chem. 2017, 6, 161-164. [CrossRef]

67. Shore, G.; Yoo, W.-J.; Li, C.-J.; Organ, M.G. Propargyl amine synthesis catalysed by gold and copper thin films by using microwave-assisted continuous-flow organic synthesis (MACOS). Chem. Eur. J. 2010, 16, 126-133. [CrossRef] [PubMed]

68. Sayyad, N.; Cele, Z.; Aleti, R.R.; Bera, M.; Cherukupalli, S.; Chandrasekaran, B.; Kushwaha, N.D.; Karpoormath, R. Coppercatalyzed self-condensation of benzamide: Domino reactions towards quinazolinones. Eur. J. Org. Chem. 2018, 2018, $5382-5388$. [CrossRef]

69. Dao, P.D.Q.; Cho, C.S.; Ho, S.L.; Sohn, H.-S. Microwave-assisted copper powder-catalyzed synthesis of azole-fused pyrimidinones. Curr. Org. Chem. 2018, 22, 85-93. [CrossRef]

70. Do Nascimento, J.E.R.; Gonçalves, L.C.C.; Hooyberghs, G.; Van der Eycken, E.V.; Alves, A.; Lenardão, E.J.; Perin, G.; Jacob, R.G. Synthesis of fused 1,2,3-triazolo-1,3,6-triazonines through copper-catalyzed intramolecular Ullmann cross-coupling reaction. Tetrahedron Lett. 2016, 57, 4885-4889. [CrossRef]

71. Li, Z.; Legras, L.; Kumar, A.; Vachhani, D.D.; Sharma, S.K.; Parmar, V.S.; Van der Eycken, E.V. Microwave-assisted synthesis of $4 \mathrm{H}$-benzo[f]imidazo[1,4]diazepin-6-ones via a post-Ugi copper-catalyzed intramolecular Ullmann coupling. Tetrahedron Lett. 2014, 55, 2070-2074. [CrossRef]

72. Rout, L.; Kumar, A.; Chand, P.K.; Achary, L.S.K.; Dash, P. Microwave-assisted efficient one-pot multi-component synthesis of octahydroquinazolinone derivatives catalyzed by Cu@Ag core-shell nanoparticle. ChemistrySelect 2019, 4, 5696-5706. [CrossRef]

73. Ke, F.; Liu, C.; Zhang, P.; Xu, J.; Chen, X. Efficient and selective microwave-assisted copper-catalyzed synthesis of quinazolinone derivatives in aqueous. Synth. Commun. 2018, 8, 3089-3098. [CrossRef]

74. Radhakrishnan, R.; Das, S.; Kundu, L.M. Synthesis of size-expanded nucleobase analogues for artificial base-pairing using a ligand-free, microwave-assisted copper(I)-catalyzed reaction. ChemistrySelect 2018, 3, 13098-13102. [CrossRef]

75. Raut, A.B.; Tiwari, A.R.; Bhanage, B.M. Ultrasonic irradiation assisted preparation of $\mathrm{Cu}_{2} \mathrm{O}-$ nanocubes and their high catalytic activity in synthesis of quinazolines. Chem CatChem 2017, 9, 1292-1297. [CrossRef]

76. Li, S.; Chen, X.; Xu, J. Microwave-assisted copper-catalyzed stereoselective ring expansion of three-membered heterocycles with $\alpha$-diazo- $\beta$-dicarbonyl compounds. Tetrahedron 2018, 74, 1613-1620. [CrossRef]

77. Chen, X.; Xu, J. Synthesis of 3-acyl-5,6-dihydro-1,4-oxathiines through ring expansion of thiiranes. Tetrahedron Lett. 2017, 58, 1651-1654. [CrossRef]

78. Baba, N.H.K.; Ashok, D.; Rao, B.A.; Sarasija, M.; Murthy, N.Y.S. Microwave-assisted synthesis of novel benzodifuran-based bis(N-(het)arylthiazol-2-amine) derivatives and their antibacterial and antimycobacterial activities. Chem. Heterocycl. Compd. 2018, 54, 658-663. [CrossRef]

79. Huang, Y.; Guo, Z.; Song, H.; Liu, Y.; Wang, Q. Silver-copper co-catalyzed cascade intramolecular cyclization/desulfinamide/dehydrogenat One-pot synthesis of substituted carbazoles. Chem. Commun. 2018, 54, 7143-7146. [CrossRef]

80. Lee, H.K.; Dao, P.D.Q.; Kim, Y.-S.; Cho, C.S. Synthesis of indolo[2,1-a]isoquinolines via copper-catalyzed c-c coupling and cyclization of 2-(2-bromoaryl)-1H-indoles with 1,3-diketones. Synthesis 2018, 50, 3243-3249. [CrossRef]

81. Padmaja, R.D.; Meena, D.R.; Maiti, B.; Chanda, K. $\left[\mathrm{Cu}(\mathrm{phen})\left(\mathrm{PPh}_{3}\right)_{2}\right] \mathrm{NO}_{3}$-catalyzed microwave-assisted green synthesis of 5-substituted 1H-tetrazoles. Res. Chem. Intermed. 2017, 43, 7365-7374. [CrossRef]

82. Chouaib, K.; Romdhane, A.; Delemasure, S.; Dutartre, P.; Elie, N.; Touboul, D.; Ben jannet, H.; Hamza, M.A. Regiospecific synthesis, anti-inflammatory and anticancer evaluation of novel 3,5-disubstituted isoxazoles from the natural maslinic and oleanolic acids. Ind. Crops Prod. 2016, 85, 287-299. [CrossRef]

83. Bachon, A.-K.; Opatz, T. Synthesis of 1,2-disubstituted indoles from $\alpha$-aminonitriles and 2-halobenzyl halides. J. Org. Chem. 2016, 81, 1858-1869. [CrossRef] [PubMed]

84. Zhao, Y.; Sharma, N.; Sharma, U.K.; Li, Z.; Song, G.; Van der Eycken, E.V. Microwave-assisted copper-catalyzed oxidative cyclization of acrylamides with non-activated ketones. Chem. Eur. J. 2016, 22, 5878-5882. [CrossRef] [PubMed]

85. Zhang, X.-Y.; Yang, Z.-W.; Chen, Z.; Wang, J.; Yang, D.-L.; Shen, Z.; Hu, L.-L.; Xie, J.-W.; Zhang, J.; Cui, H.-L. Tandem copper-catalyzed propargylation/alkyne azacyclization/isomerization reaction under microwave irradiation: Synthesis of fully substituted pyrroles. J. Org. Chem. 2016, 81, 1778-1785. [CrossRef] [PubMed]

86. Abda, H.; Aouadi, K.; Brahmi, J.; Msaddek, M.; Vidal, S. Unexpected synthesis of aziridines under Cu(I) catalyzed Kinugasa conditions assisted by microwave irradiation. C. R. Chim. 2016, 19, 275-278. [CrossRef]

87. Kumar, G.S.; Ragini, S.P.; Kumar, A.S.; Meshram, H.M. Copper-catalyzed multi-component reaction accessing fused imidazoheterocycles via C $-\mathrm{H}$ functionalization. RSC Adv. 2015, 5, 51576-51580. [CrossRef]

88. Orrego-Hernández, J.; Cobo, J.; Portilla, J. Chemoselective synthesis of 5-alkylamino-1H-pyrazole-4-carbaldehydes by cesiumand copper-mediated amination. Eur. J. Org. Chem. 2015, 5064-5069. [CrossRef]

89. Hu, Z.; Ou, L.-L.; Li, S.-D.; Yang, L. Efficient copper(I)-catalyzed, microwave-assisted, one-pot synthesis of 3,4-diaryl isoquinolines Res. Chem. Intermed. 2015, 41, 3461-3469. [CrossRef]

90. Jiao, Y.; Cho, C.S. Microwave-assisted copper powder-catalyzed coupling and cyclization of $\beta$-bromo- $\alpha, \beta$-unsaturated amides with amidine hydrochlorides leading to pyrimidinones. Appl. Organometal. Chem. 2015, 29, 372-375. [CrossRef]

91. Ho, S.L.; Cho, C.S. Microwave-assisted copper-powder-catalyzed synthesis of pyrimidinones from $\beta$-bromo- $\alpha$, $\beta$-unsaturated carboxylic acids and amidines. Synlett 2013, 24, 2705-2708. [CrossRef] 
92. Pasunooti, K.K.; Chai, H.; Jensen, C.N.; Gorityala, B.K.; Wang, S.; Liu, X.-W. A microwave-assisted, copper-catalyzed threecomponent synthesis of dihydropyrimidinones under mild conditions. Tetrahedron Lett. 2011, 52, 80-84. [CrossRef]

93. Murugavel, G.; Punniyamurthy, T. Microwave-assisted copper-catalyzed four-component tandem synthesis of 3-Nsulfonylamidine coumarins. J. Org. Chem. 2015, 80, 6291-6299. [CrossRef] [PubMed]

94. Ho, S.L.; Cho, C.S.; Sohn, H.-S. Microwave-assisted copper-powder-catalyzed coupling and cyclization of $\beta$-bromo- $\alpha, \beta-$ unsaturated carboxylic acids with 1,3-diketones leading to 2H-pyran-2-ones. Synthesis 2015, 47, 216-220. [CrossRef]

95. Naresh, G.; Kant, R.; Narender, T. Copper(II) catalyzed expeditious synthesis of furoquinoxalines through a one-pot threecomponent coupling strategy. Org. Lett. 2014, 16, 4528-4531. [CrossRef]

96. Zhao, F.; Zhang, L.; Liu, H.; Zhou, S.; Liu, H. Microwave-assisted synthesis of 5,6-dihydroindolo[1,2-a]quinoxaline derivatives through copper-catalyzed intramolecular N-arylation. Beilstein J. Org. Chem. 2013, 9, 2463-2469. [CrossRef]

97. Shekarrao, K.; Kaishap, P.P.; Gogoi, S.; Boruah, R.C. Efficient synthesis of isoquinolines and pyridines via copper(I)-catalyzed multi-component reaction. RSC Adv. 2014, 4, 14013-14023. [CrossRef]

98. Dell'Acqua, M.; Abbiati, G.; Rossi, E. Palladium-catalyzed, microwave-enhanced three-component synthesis of isoquinolines with aqueous ammonia. Synlett 2010, 17, 2672-2676. [CrossRef]

99. Kosurkar, U.B.; Dadmal, T.L.; Appalanaidu, K.; Rao, Y.K.; Nanubolu, J.B.; Kumbhare, R.M. Microwave assisted synthesis of 2-aminooxazolo [4,5-b] pyridine derivatives via intramolecular $\mathrm{C}-\mathrm{O}$ bond formation in aqueous medium. Tetrahedron Lett. 2014, 55, 1296-1298. [CrossRef]

100. Vasilyev, E.S.; Agafontsev, A.M.; Tkachev, A.V.; Vasilyev, E.S.; Agafontsev, A.M.; Tkachev, A.V. Microwave-assisted synthesis of chiral nopinane-annelated pyridines by condensation of pinocarvone oxime with enamines promoted by $\mathrm{FeCl}_{3}$ and $\mathrm{CuCl}_{2}$. Synth . Commun. 2014, 44, 1817-1824. [CrossRef]

101. Pasunooti, K.K.; Jensen, C.N.; Chai, H.; Leow, M.L.; Zhang, D.-W.; Liu, X.-W. Microwave-assisted copper (II)-catalyzed one-pot four-component synthesis of multifunctionalized dihydropyridines. J. Comb. Chem. 2010, 12, 577-581. [CrossRef]

102. Gyuris, M.; Puskás, L.G.; Tóth, G.K.; Kanizsai, I. Synthesis of novel pyrazole-based heterocycles via a copper (II)-catalysed domino annulation. Org. Biomol. Chem. 2013, 11, 6320-6327. [CrossRef]

103. Mastalir, M.; Rosenberg, E.E.; Kirchner, K. A practical synthesis of substituted 2,6-diaminopyridines via microwave-assisted copper-catalyzed amination of halopyridines. Tetrahedron 2015, 71, 8104-8110. [CrossRef]

104. Suh, J.; Kang, H.S.; Kim, J.-E.; Yum, E.K. Diversification of pyrazoles by microwave-assisted ligand free copper catalyzed N-arylation. Bull. Korean Chem. Soc. 2012, 33, 2067-2070. [CrossRef]

105. Olson, J.P.; Carroll, F.I. An improved synthesis of phenylethynyl[1,2,4]methyltriazines. Synthesis 2011, 3, 0409-0412. [CrossRef]

106. Kumar, A.S.; Rao, P.V.A.; Nagarajan, R. Microwave-assisted one-pot synthesis of pyrazolo[3,4-b]indoles and new isoxazolo[5,4b]indoles via copper-catalyzed intramolecular C-N/C-O bond formation. Synthesis 2011, 23, 3878-3886. [CrossRef]

107. Gu, L.; Li, X. Microwave-assisted synthesis of indole-2-carboxylic acid esters in ionic liquid. J. Braz. Chem. Soc. 2011, 22, 2036-2039. [CrossRef]

108. Zhong, Q.-F.; Sun, L.-P. An efficient synthesis of 6,9-disubstituted purin-8-ones via copper-catalyzed coupling/cyclization. Tetrahedron 2010, 66, 5107-5111. [CrossRef]

109. Peshkov, V.A.; Pereshivko, O.P.; Donets, P.A.; Mehta, V.P.; Van der Eycken, E.V. Diversity-oriented microwave-assisted synthesis of the 3-benzazepine framework. Eur. J. Org. Chem. 2010, 4861-4867. [CrossRef]

110. Bariwal, J.B.; Ermolat'ev, D.S.; Glasnov, T.N.; Van Hecke, K.; Mehta, V.P.; Van Meervelt, L.; Kappe, C.O.; Van der Eycken, E.V. Diversity-oriented synthesis of dibenzoazocines and dibenzoazepines via a microwave-assisted intramolecular $\mathrm{A}^{3}$-coupling reaction. Org. Lett. 2012, 12, 2774-2777. [CrossRef]

111. Yadav, A.; Biswas, S.; Mobin, S.M.; Samanta, S. Efficient Cu (OTf $)_{2}$-catalyzed and microwave-assisted rapid synthesis of 3,4-fused chromenopyridinones under neat conditions. Tetrahedron Lett. 2017, 58, 3634-3639. [CrossRef]

112. Yang, H.J.; Mathew, B.P.; Oh, D.G.; Myung, K.; Kwak, J.H.; Hong, S.Y. Efficient copper catalysts for CH bond arylation under microwave heating: Direct access to multi-substituted pivanilides. Catal. Commun. 2017, 90, 83-86. [CrossRef]

113. Harari, M.; Couly, F.; Fruit, C.; Besson, T. Pd-catalyzed and copper assisted regioselective sequential C2 and C7 arylation of thiazolo[5,4-f]quinazolin-9(8H)-one with aryl halides. Org. Lett. 2016, 18, 3282-3285. [CrossRef] [PubMed]

114. Laclef, S.; Harari, M.; Godeau, J.; Schmitz-Afonso, I.; Bischoff, L.; Hoarau, C.; Levacher, V.; Fruit, C.; Besson, T. Ligand-free Pd-catalyzed and copper-assisted $\mathrm{C}-\mathrm{H}$ arylation of quinazolin-4-ones with aryl iodides under microwave heating. Org. Lett. 2015, 17, 1700-1703. [CrossRef] [PubMed]

115. Yuan, J.; Zhu, J.; Fu, J.; Yang, L.; Xiao, Y.; Mao, P.; Du, X.; Qu, L. Highly efficient copper-catalyzed direct C-H amidation of quinoxalin-2(1H)-ones with amidates under microwave irradiation. Org. Chem. Front. 2019, 6, 925-935. [CrossRef]

116. Vabre, R.; Chevot, F.; Legraverend, M.; Piguel, S. Microwave-assisted Pd/Cu-catalyzed C-8 direct alkenylation of purines and related azoles: An alternative access to 6,8,9-trisubstituted purines. J. Org. Chem. 2011, 76, 9542-9547. [CrossRef]

117. Abe, T.; Takeda, H.; Takahashi, Y.; Miwa, Y.; Yamada, K.; Ishikura, M. Metal-catalyzed reactions between 2-azabicyclo[2.2.1]hept5-en-3-ones and arylboronic acids. Eur. J. Org. Chem 2010, 3281-3294. [CrossRef]

118. Tambe, Y.B.; Sharma, S.; Pathak, A.; Reddy, L.K. Microwave-assisted N-cyclopropylation of pyridinols with cyclopropyl boronic acid. Synth. Commun. 2012, 42, 1341-1348. [CrossRef]

119. Al-Masum, M.; Islam, M.S.; Shaban, W. Cu-Pd dual catalyst system for amide styrylation reaction from potassium styryltrifluoroborates and amides. Int. J. Org. Chem. 2017, 7, 254-262. [CrossRef] 
120. Chang, R.K.; Clairmont, B.P.; Lin, S.; MacArthur, A.H.R. Amidation of aryl chlorides using a microwave-assisted, copper-catalyzed concurrent tandem catalytic methodology. Organometallic 2019, 38, 4448-4454. [CrossRef]

121. Iwasaki, M.; Xu, J.; Tani, Y.; Fu, L.; Ikemoto, Y.; Ura, Y.; Nishihara, Y. Copper-catalyzed regioselective chloroamination of alkenes with chlorotrimethylsilane and N-fluorobenzenesulfonimide under microwave-assisted conditions. Chem. Lett. 2019, 48, 281-284. [CrossRef]

122. Taj, M.B.; Raheel, A.; Alelwani, W.; Babteen, N.; Kattan, S.; Alnajeebi, A.; Sharif, M.; Ahmad, R.H.; Abbas; Hazeeq, A.; et al. One-pot CuO-catalyzed green synthesis of $\mathrm{N}(\mathrm{N})$-arylbenzamidines as potential enzyme inhibitors. Russ. J. Org. Chem. 2019, 55, 1047-1052. [CrossRef]

123. Sarada, R.; Jagannadharao, V.; Govindh, B.; Padma, M. A facile microwave assisted neat synthesis of bis-amides using nano nickel copper ferrite as amicable catalyst and study of their fluorescence studies. Pharma Chem. 2017, 9, 115-119.

124. Nematpour, M.; Abedi, E. A microwave-assisted new synthesis of sulfonylidene-sulfonamide via reactions of $\mathrm{N}$-sulfonylketenimine and sodium arylsulfinates. J. Sulfur Chem. 2017, 38, 76-82. [CrossRef]

125. Nekkanti, S.; Veeramani, K.; Kumar, N.P.; Shankaraiah, N. Microwave-assisted direct oxidative synthesis of $\alpha$-ketoamides from aryl methyl ketones and amines by a water soluble Cu (I)-complex. Green Chem. 2016, 18, 3439-3447. [CrossRef]

126. Navarro, L.; Pujol, M.D. Microwave assisted synthesis of selected diaryl ethers under Cu (I)-catalysis. Tetrahedron Lett. 2015, 56, 1812-1815. [CrossRef]

127. Mehmood, A.; Devine, W.G.; Leadbeater, N.E. Development of methodologies for copper-catalyzed C-O bond formation and direct cyanation of aryl iodides. Top. Catal. 2010, 53, 1073-1080. [CrossRef]

128. Chen, Y.-A.; Badsara, S.S.; Tsai, W.-T.; Lee, C.-F. Microwave-assisted copper-catalyzed cross-coupling reaction of thiols with aryl iodides in water. Synthesis 2015, 47, 181-186. [CrossRef]

129. Sun, W.; Patel, P.D.; Stephani, R.A.; Chiosis, G. An efficient copper-catalyzed microwave-assisted S-arylation towards the synthesis of 8-arylsulfanyl adenines. Synlett 2011, 20, 3008-3012. [CrossRef]

130. Botteselle, G.V.; Godoi, M.; Galetto, F.Z.; Bettanin, L.; Singh, D.; Rodrigues, O.E.D.; Braga, A.L. Microwave-assisted one-pot synthesis of symmetrical diselenides, ditellurides and disulfides from organoyl iodides and elemental chalcogen catalyzed by CuO nanoparticles. J. Mol. Catal. A Chem. 2012, 365, 186-193. [CrossRef]

131. Beletskaya, I.P.; Sigeev, A.S.; Peregudov, A.S.; Petrovskii, P.V.; Khrustalev, V.N. Microwave-assisted synthesis of diaryl selenides. Elucidation of $\mathrm{Cu}(\mathrm{I})$-catalyzed reaction mechanism. Chem. Lett. 2010, 39, 720-722. [CrossRef]

132. Saba, S.; Botteselle, G.V.; Godoi, M.; Frizon, T.E.A.; Galetto, F.Z.; Rafique, J.; Braga, A.L. Copper-catalyzed synthesis of unsymmetrical diorganyl chalcogenides (Te/Se/S) from boronic acids under solvent-free conditions. Molecules 2017, 22, 1367. [CrossRef] [PubMed]

133. Priya, S.S.; Selvakannan, P.R.; Chary, K.V.R.; Kantam, M.L.; Bhargava, S.K. Solvent-free microwave-assisted synthesis of solketal from glycerol using transition metal ions promoted mordenite solid acid catalysts. Mol. Catal. 2017, 434, 184-193. [CrossRef]

134. Nandi, G.C. An efficient Cu-catalyzed microwave-assisted synthesis of diaryl sulfones. Synth. Commun. 2017, 47, 319-323. [CrossRef]

135. Jha, M.; Shelke, G.M.; Pericherla, K.; Kumar, A. Microwave assisted copper triflate-catalyzed rapid hydration of aryl acetylenes. Tetrahedron Lett. 2014, 55, 4814-4816. [CrossRef]

136. Gáiná, L.I.; Mátárângá-Popa, L.N.; Gal, E.; Boar, P.; Lönnecke, P.; Hey-Hawkins, E.; Bischin, C.; Silaghi-Dumitrescu, R.; Lupan, I.; Cristea, C.; et al. Microwave-assisted catalytic amination of phenothiazine; Reliable access to phenothiazine analogues of Tröger's base. Eur. J. Org. Chem. 2013, 5500-5508. [CrossRef]

137. Ke, F.; Chen, X.; Li, Z.; Xiang, H.; Zhou, X. Microwave-assisted copper-catalyzed hydroxylation of aryl halides in water. RSC Adv. 2013, 3, 22837-22840. [CrossRef]

138. Paik, S.; Jung, M.G. Rapid microwave-assisted copper-catalyzed nitration of aromatic halides with nitrite salts. Bull. Korean Chem. Soc. 2012, 33, 689-691. [CrossRef]

139. Feng, H.; Li, Y.; Lin, S.; Van der Eycken, E.V.; Song, G. Nano Cu-catalyzed efficient and selective reduction of nitroarenes under combined microwave and ultrasound irradiation. Sustain. Chem. Proces. 2014, 2, 14. [CrossRef]

140. Montel, S.; Bouyssi, D.; Balme, G. An efficient and general microwave-assisted copper-catalyzed conia-ene reaction of terminal and internal alkynes tethered to a wide variety of carbonucleophiles. Adv. Synth. Catal. 2010, 352, 2315-2320. [CrossRef]

141. Romano, P.N.; de Almeida, J.M.A.R.; Carvalho, Y.; Priecel, P.; Sousa-Aguiar, E.F.; Lopez-Sanchez, J.A. Microwave-assisted selective hydrogenation of furfural to furfuryl alcohol employing a green and noble metal-free copper catalyst. ChemSusChem 2016, 9, 3387-3392. [CrossRef] 